\title{
Bis-triazolylchalcogenium-functionalized benzothiadiazole derivatives as light-up sensors for DNA and BSA
}

Roberta Krüger, ${ }^{[a]}$ Allya Larroza, ${ }^{[a]}$ Mariana G. Fronza, ${ }^{[b]}$ Isadora Tisoco, ${ }^{[c]}$ Lucielli Savegnago, ${ }^{[\mathrm{b}]}$ Joel S. Reis, ${ }^{[\mathrm{d}]}$ Davi F. Back, ${ }^{[\mathrm{e}]}$ Bernardo A. Iglesias, ${ }^{*[\mathrm{~b}]}$ and Diego Alves ${ }^{\left[{ }^{[a}{ }^{*}\right.}$

a Clean Organic Synthesis Laboratory - LASOL - CCQFA - Federal University of Pelotas - UFPel, CEP 96010900, Pelotas, RS, Brazil.

${ }^{b}$ Neurobiotechnology Research Group - GPN, CDTec, Federal University of Pelotas, UFPel, CEP: $96010-$ 900, Pelotas, RS, Brazil.

c Chemistry Department, Bioinorganics and Porphyrinic Materials Laboratory, Federal University of Santa Maria, UFSM, CEP: 97105-900 Santa Maria, RS, Brazil.

d Institute of Chemistry, Fluminense Federal University, UFF, CEP: 24020-141, Niteroi, RJ, Brazil.

e Chemistry Department, Inorganic Materials Laboratory, Federal University of Santa Maria, UFSM, CEP: 97105-900 Santa Maria, RS, Brazil.

*Corresponding authors: E-mail: bernardopgq@gmail.com, bernardo.iglesias@ufsm.br, and diego.alves@ufpel.edu.br; Phone / Fax: (+) 555332757533.

\section{Contents}

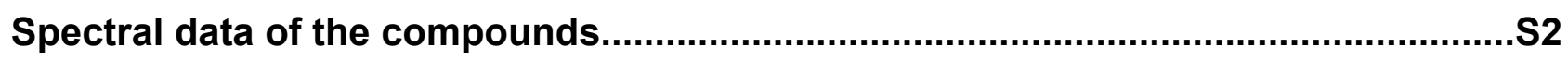

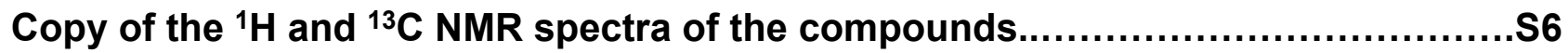

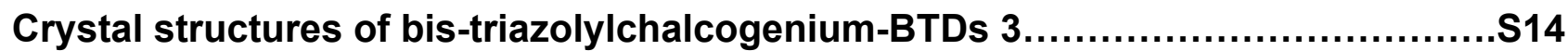

Electrochemical behavior of bis-triazolylchalcogenium-BTDs $3 \ldots \ldots \ldots \ldots \ldots \ldots \ldots \ldots . . . . . \ldots 20$

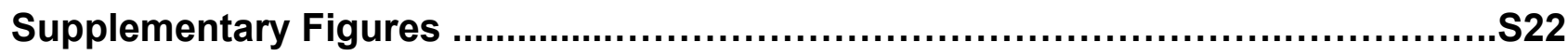


Spectral data of the compounds:

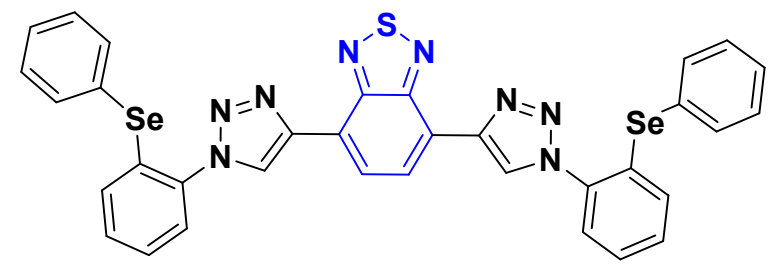

\section{4,7-bis(1-(2-(phenylselanyl)phenyl)-1H-1,2,3-triazol-4-yl)benzo[c][1,2,5]thiadiazole}

(3a): Isolated by column chromatography on neutral alumina using a mixture of ethyl acetate/hexanes (20:80) as the eluent. Yield: $0.160 \mathrm{~g}(87 \%)$; When the reaction was carried out in a $2.5 \mathrm{mmol}$ scale, the compound 3 a was obtained in $74 \%$ yield $(1.358 \mathrm{~g})$; orange solid; mp 203-205 ${ }^{\circ} \mathrm{C} .{ }^{1} \mathrm{H}$ NMR (400 MHz, $\mathrm{CDCl}_{3}$ ) ס: 9.05 (s, 2H); 8.73 (s, 2H); 7.53 - 7.45 (m, $6 \mathrm{H}) ; 7.35-7.23(\mathrm{~m}, 12 \mathrm{H}) .{ }^{13} \mathrm{C}\left\{{ }^{1} \mathrm{H}\right\}$ NMR $\left(100 \mathrm{MHz}, \mathrm{CDCl}_{3}\right)$ ס: 152.6; 143.4; 137.3; 135.4; 133.6; 130.6; 129.9; 129.3; 128.9; 128.0;126.7; 126.4; 125.6; 122.8. MS m/z (relative intensity): 734 (2), 629 (42), 521 (100), 364 (75), 232 (8). HRMS (ESI) m/z: [M + H] Calcd. for $\mathrm{C}_{34} \mathrm{H}_{22} \mathrm{~N}_{8} \mathrm{SSe}_{2}$ 735.0097; Found 735.0077.

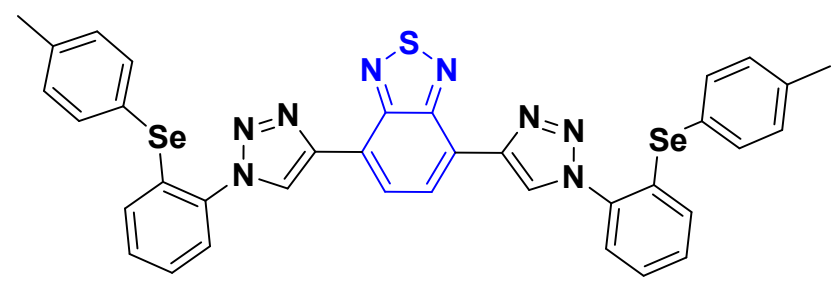

\section{4,7-bis(1-(2-(p-tolylselanyl)phenyl)-1H-1,2,3-triazol-4-yl)benzo[c][1,2,5]thiadiazole}

(3b): Isolated by column chromatography on neutral alumina using a mixture of ethyl acetate/hexanes (20:80) as the eluent. Yield: $0.147 \mathrm{~g}(77 \%)$; yellow solid; $\mathrm{mp} 185-187{ }^{\circ} \mathrm{C}$.

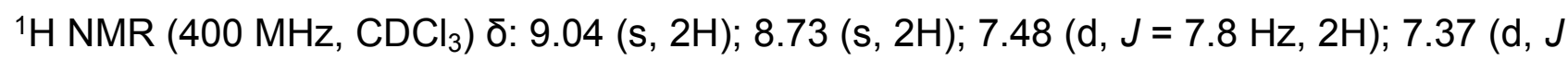
$=7.8 \mathrm{~Hz}, 4 \mathrm{H}) ; 7.33-7.21(\mathrm{~m}, 6 \mathrm{H}) ; 7.05(\mathrm{~d}, J=7.7 \mathrm{~Hz}, 4 \mathrm{H}) ; 2.26(\mathrm{~s}, 6 \mathrm{H}) .{ }^{13} \mathrm{C}\left\{{ }^{1} \mathrm{H}\right\} \mathrm{NMR}(100$ $\mathrm{MHz}_{\mathrm{CDCl}}$ ) ठ: 152.6; 143.4; 139.3; 136.8; 135.9; 132.9; 131.3; 130.8; 130.5; 127.6; 126.7; 126.3; 125.6; 125.2; 122.8; 21.5. MS m/z (relative intensity): 762 (5), 535 (100), 364 (78), 287 (15), 152 (52). HRMS (ESI) m/z: [M + H] Calcd. for $\mathrm{C}_{36} \mathrm{H}_{26} \mathrm{~N}_{8} \mathrm{SSe}_{2}$ 763.0411; Found 763.0409 . 


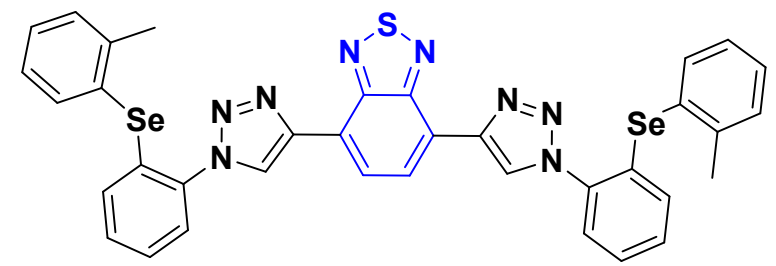

\section{4,7-bis(1-(2-(o-tolylselanyl)phenyl)-1H-1,2,3-triazol-4-yl)benzo[c][1,2,5]thiadiazole}

(3c): Isolated by column chromatography on neutral alumina using a mixture of ethyl acetate/hexanes (20:80) as the eluent. Yield: $0.118 \mathrm{~g}(62 \%)$; orange solid; mp $163-165{ }^{\circ} \mathrm{C}$. ${ }^{1} \mathrm{H} \mathrm{NMR}\left(400 \mathrm{MHz}, \mathrm{CDCl}_{3}\right) \delta: 9.04(\mathrm{~s}, 2 \mathrm{H}) ; 8.72(\mathrm{~s}, 2 \mathrm{H}) ; 7.51$ (d, $\left.J=7.7 \mathrm{~Hz}, 2 \mathrm{H}\right) ; 7.44$ (d, J $=7.7 \mathrm{~Hz}, 2 \mathrm{H}) ; 7.33(\mathrm{t}, J=7.2 \mathrm{~Hz}, 2 \mathrm{H}) ; 7.25-7.14(\mathrm{~m}, 8 \mathrm{H}) ; 7.04(\mathrm{~m}, 2 \mathrm{H}) ; 2.24(\mathrm{~s}, 6 \mathrm{H})$. ${ }^{13} \mathrm{C}\left\{{ }^{1} \mathrm{H}\right\}$ NMR $\left(100 \mathrm{MHz}, \mathrm{CDCl}_{3}\right)$ ס: 152.2; 143.1; 141.6; 136.9; 136.2; 132.6; 130.6; 130.2; $129.7 ; 129.6 ; 129.2 ; 127.5 ; 127.0 ; 126.3 ; 126.2 ; 125.2 ; 122.5 ; 22.6 . \mathrm{MS} \mathrm{m} / \mathrm{z}$ (relative intensity): 762 (2), 615 (58), 535 (69), 444 (100), 364 (85). HRMS (ESI) m/z: [M + H] Calcd. for $\mathrm{C}_{36} \mathrm{H}_{26} \mathrm{~N}_{8} \mathrm{SSe}_{2}$ 763.0411; Found 763.0408.

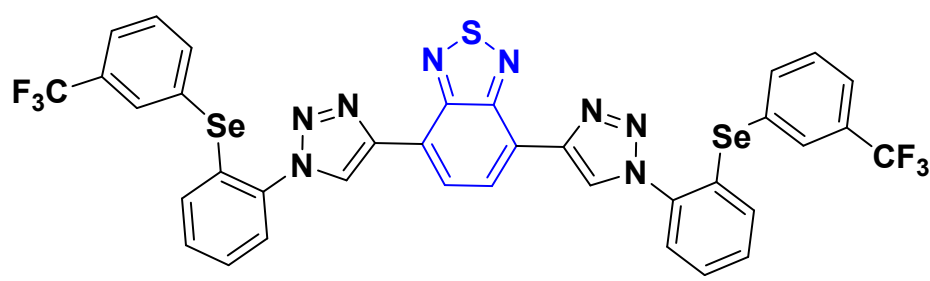

\section{4,7-bis(1-(2-((3-(trifluoromethyl)phenyl)selanyl)phenyl)-1H-1,2,3-triazol-4-}

yl)benzo[c][1,2,5]thiadiazole (3d): Isolated by column chromatography on neutral alumina using a mixture of ethyl acetate/hexanes (20:80) as the eluent. Yield: $0.115 \mathrm{~g}(53 \%)$; yellow solid; mp 185-187 ${ }^{\circ} \mathrm{C} .{ }^{1} \mathrm{H} \mathrm{NMR}\left(400 \mathrm{MHz}, \mathrm{CDCl}_{3}\right)$ ס: 9.03 (s, 2H); 8.70 (s, 2H); 7.67 (s, 2H); 7.57 (t, $J=8.7 \mathrm{~Hz}, 4 \mathrm{H}) ; 7.49-7.29(\mathrm{~m}, 10 \mathrm{H}) .{ }^{13} \mathrm{C}\left\{{ }^{1} \mathrm{H}\right\} \mathrm{NMR}\left(100 \mathrm{MHz}, \mathrm{CDCl}_{3}\right)$ ठ: 152.2; 143.2; 137.6; 137.4; 134.1; 131.8 (q, $J=32.5 \mathrm{~Hz}$ ); 130.8 (q, $J=3.6 \mathrm{~Hz}$ ); 130.7; 130.5; 129.9; 128.8; 128.5; $127.5 ; 126.4 ; 126.2 ; 125.2 ; 123.4$ (q, $J=272.6 \mathrm{~Hz})$ 122.4. MS m/z (relative intensity): 870 (7), 589 (100), 444 (92), 364 (85), 232 (23). HRMS (ESI) m/z: [M + H] Calcd. for $\mathrm{C}_{36} \mathrm{H}_{20} \mathrm{~F}_{6} \mathrm{~N}_{8} \mathrm{SSe}_{2}$ 870.9845; Found 870.9838 . 


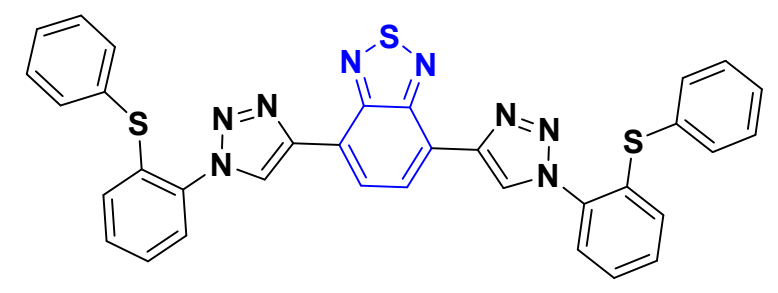

4,7-bis(1-(2-(phenylthio)phenyl)-1H-1,2,3-triazol-4-yl)benzo[c][1,2,5]thiadiazole (3e): Isolated by column chromatography on neutral alumina using a mixture of ethyl acetate/hexanes (20:80) as the eluent. Yield: $0.132 \mathrm{~g}(83 \%)$; orange solid; $\mathrm{mp} 171-173^{\circ} \mathrm{C}$. ${ }^{1} \mathrm{H}$ NMR (400 MHz, $\mathrm{CDCl}_{3}$ ) $\delta: 9.06$ (s, 2H); 8.67 (s, 2H); 7.56 (m, 2H); $7.41-7.20$ (m, 16H). ${ }^{13} \mathrm{C}\left\{{ }^{1} \mathrm{H}\right\}$ NMR $\left(100 \mathrm{MHz}, \mathrm{CDCl}_{3}\right) \delta: 152.5 ; 143.2 ; 136.8 ; 133.5 ; 132.7 ; 132.6 ; 130.6 ; 129.8$; 128.5; 128.1; 127.3; 126.6; 126.3; 122.8. MS m/z (relative intensity): 638 (2), 505 (100), 396 (46), 294 (16), 184 (33). HRMS (ESI) m/z: [M + H] Calcd. for $\mathrm{C}_{34} \mathrm{H}_{22} \mathrm{~N}_{8} \mathrm{~S}_{3}$ 639.1202; Found 639.1201.

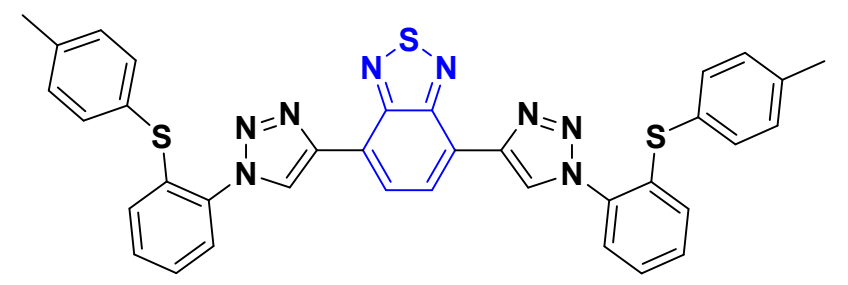

4,7-bis(1-(2-(p-tolylthio)phenyl)-1H-1,2,3-triazol-4-yl)benzo[c][1,2,5]thiadiazole (3f): Isolated by column chromatography on neutral alumina using a mixture of ethyl acetate/hexanes (20:80) as the eluent. Yield: $0.126 \mathrm{~g}(76 \%)$; yellow solid; $\mathrm{mp} 175-177^{\circ} \mathrm{C}$. ${ }^{1} \mathrm{H} \mathrm{NMR}\left(400 \mathrm{MHz}, \mathrm{CDCl}_{3}\right)$ ס: $9.06(\mathrm{~s}, 2 \mathrm{H}) ; 8.70(\mathrm{~s}, 2 \mathrm{H}) ; 7.54-7.49(\mathrm{~m}, 2 \mathrm{H}) ; 7.30(\mathrm{~m}, 4 \mathrm{H})$; $7.20(\mathrm{~m}, 6 \mathrm{H}) ; 7.04(\mathrm{~d}, J=7,9 \mathrm{~Hz}, 4 \mathrm{H}) ; 2.23(\mathrm{~s}, 6 \mathrm{H}) .{ }^{13} \mathrm{C}\left\{{ }^{1} \mathrm{H}\right\} \mathrm{NMR}\left(100 \mathrm{MHz}, \mathrm{CDCl}_{3}\right) \delta: 152.5$, 143.2, 139.0, 136.1, 134.8, 133.7, 131.4, 130.6, 130.5, 129.0, 127.4, 127.2, 126.6, 126.3, 122.8, 21.5. MS m/z (relative intensity): 666 (2), 519 (100), 428 (44), 295 (13), 184 (20). HRMS (ESI) m/z: [M + H] Calcd. for $\mathrm{C}_{36} \mathrm{H}_{26} \mathrm{~N}_{8} \mathrm{~S}_{3}$ 667.1515; Found 667.1516 . 


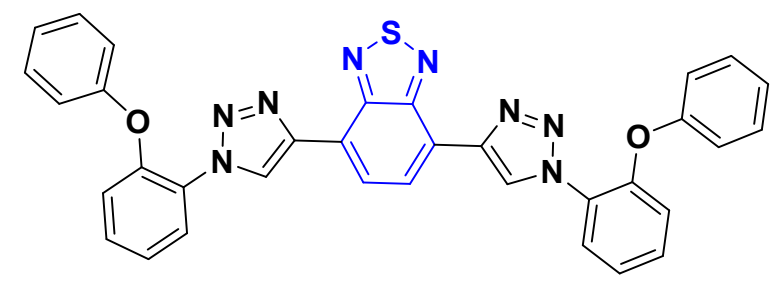

4,7-bis(1-(2-phenoxyphenyl)-1H-1,2,3-triazol-4-yl)benzo[c][1,2,5]thiadiazole

(3g):

Isolated by column chromatography on neutral alumina using a mixture of ethyl acetate/hexanes (20:80) as the eluent. Yield: $0.104 \mathrm{~g}(69 \%)$; orange solid; mp $71-73{ }^{\circ} \mathrm{C} .{ }^{1} \mathrm{H}$ NMR (400 MHz, $\left.\mathrm{CDCl}_{3}\right)$ ס: $9.32(\mathrm{~s}, 2 \mathrm{H}) ; 8.69(\mathrm{~s}, 2 \mathrm{H}) ; 7.46-7.31(\mathrm{~m}, 12 \mathrm{H}) ; 7.14-7.10(\mathrm{~m}$, $6 \mathrm{H}) .{ }^{13} \mathrm{C}\left\{{ }^{1} \mathrm{H}\right\}$ NMR $\left(100 \mathrm{MHz}, \mathrm{CDCl}_{3}\right) \delta: 156.5 ; 152.7 ; 149.3 ; 143.6 ; 130.7 ; 130.5 ; 129.2$; 126.6; 126.4; 126.2; 124.8; 124.6; 123.0; 120.5; 119.2. MS m/z (relative intensity): 606 (2), 505 (100), 396 (46), 294 (16), 184 (33). HRMS (ESI) m/z: [M + Na] Calcd. for $\mathrm{C}_{34} \mathrm{H}_{22} \mathrm{~N}_{8} \mathrm{O}_{2} \mathrm{SNa}$ 629.1479; Found 629.1450.

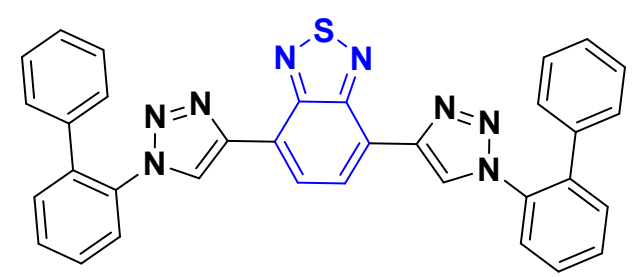

4,7-bis(1-([1,1'-biphenyl]-2-yl)-1H-1,2,3-triazol-4 yl)benzo[c][1,2,5]thiadiazole (3h): Isolated by column chromatography on neutral alumina using a mixture of ethyl acetate/hexanes (20:80) as the eluent. Yield: $0.082 \mathrm{~g}(57 \%)$; yellow solid; mp 184-186 ${ }^{\circ} \mathrm{C}$. ${ }^{1} \mathrm{H} \mathrm{NMR}\left(400 \mathrm{MHz}, \mathrm{CDCl}_{3}\right)$ ס: 8.61 (s, 2H); 8.44 (s, 2H); 7.73 (d, J = $\left.7.4 \mathrm{~Hz}, 2 \mathrm{H}\right) ; 7.63-7.55$ $(\mathrm{m}, 6 \mathrm{H}) ; 7.27-7.18(\mathrm{~m}, 10 \mathrm{H}) .{ }^{13} \mathrm{C}\left\{{ }^{1} \mathrm{H}\right\} \mathrm{NMR}\left(100 \mathrm{MHz}, \mathrm{CDCl}_{3}\right)$ ठ: 151.8; 142.6; 137.2; 134.9; $131.1 ; 129.8 ; 128.5 ; 128.4 ; 128.3 ; 127.7 ; 126.4 ; 125.9 ; 125.8 ; 122.2 . \mathrm{MS} \mathrm{m} / \mathrm{z}$ (relative intensity): 574 (2), 521 (100), 364 (75), 232 (8), 184 (33). HRMS (ESI) m/z: [M + H] Calcd. for $\mathrm{C}_{34} \mathrm{H}_{22} \mathrm{~N}_{8} \mathrm{~S} 575.1761$; Found 575.1726. 
Copy of the ${ }^{1} \mathrm{H}$ and ${ }^{13} \mathrm{C}$ NMR spectra of the compounds

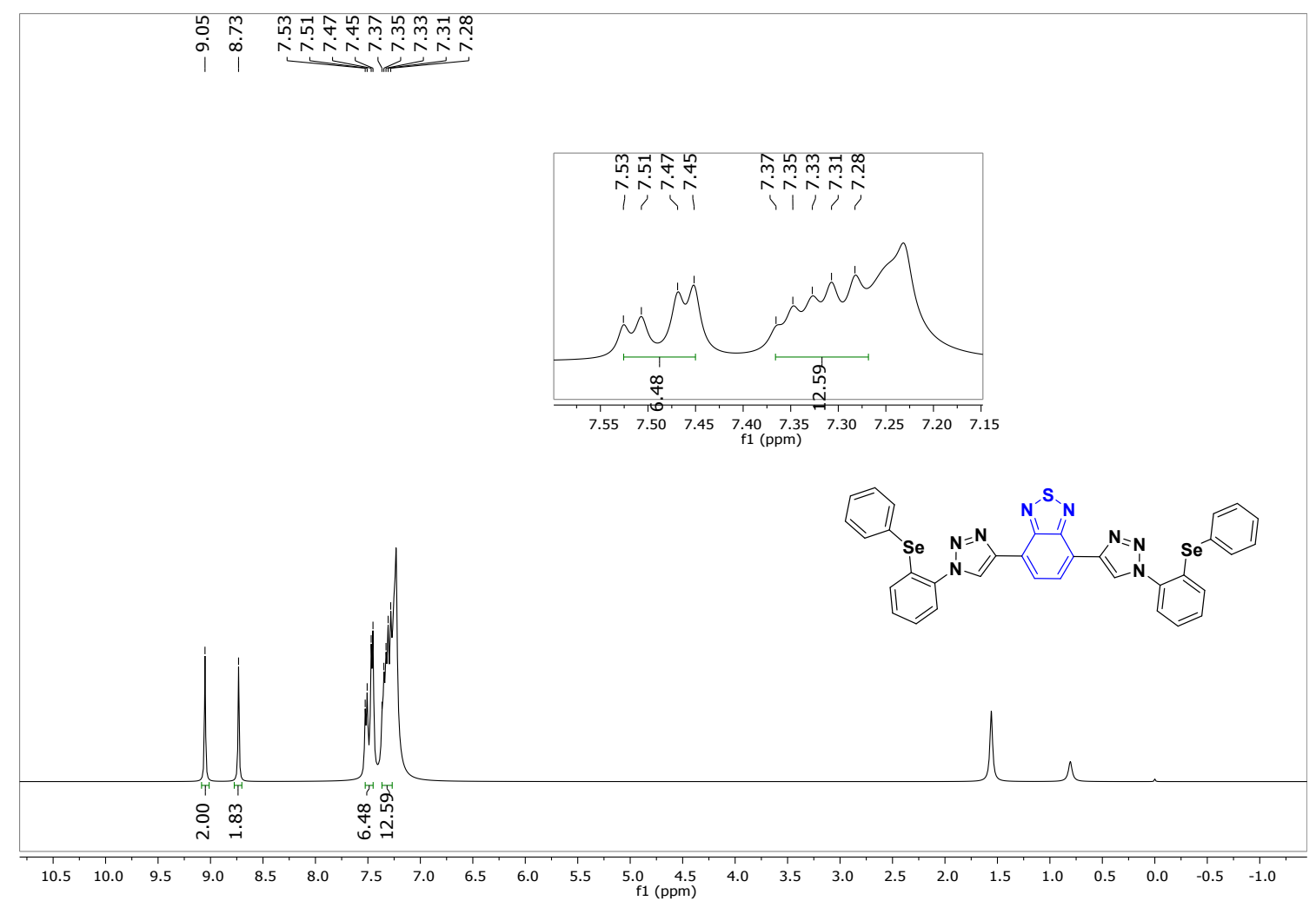

Figure S1. ${ }^{1} \mathrm{H}$ NMR $(400 \mathrm{MHz})$ spectrum for compound $3 \mathrm{a}$ in $\mathrm{CDCl}_{3}$.

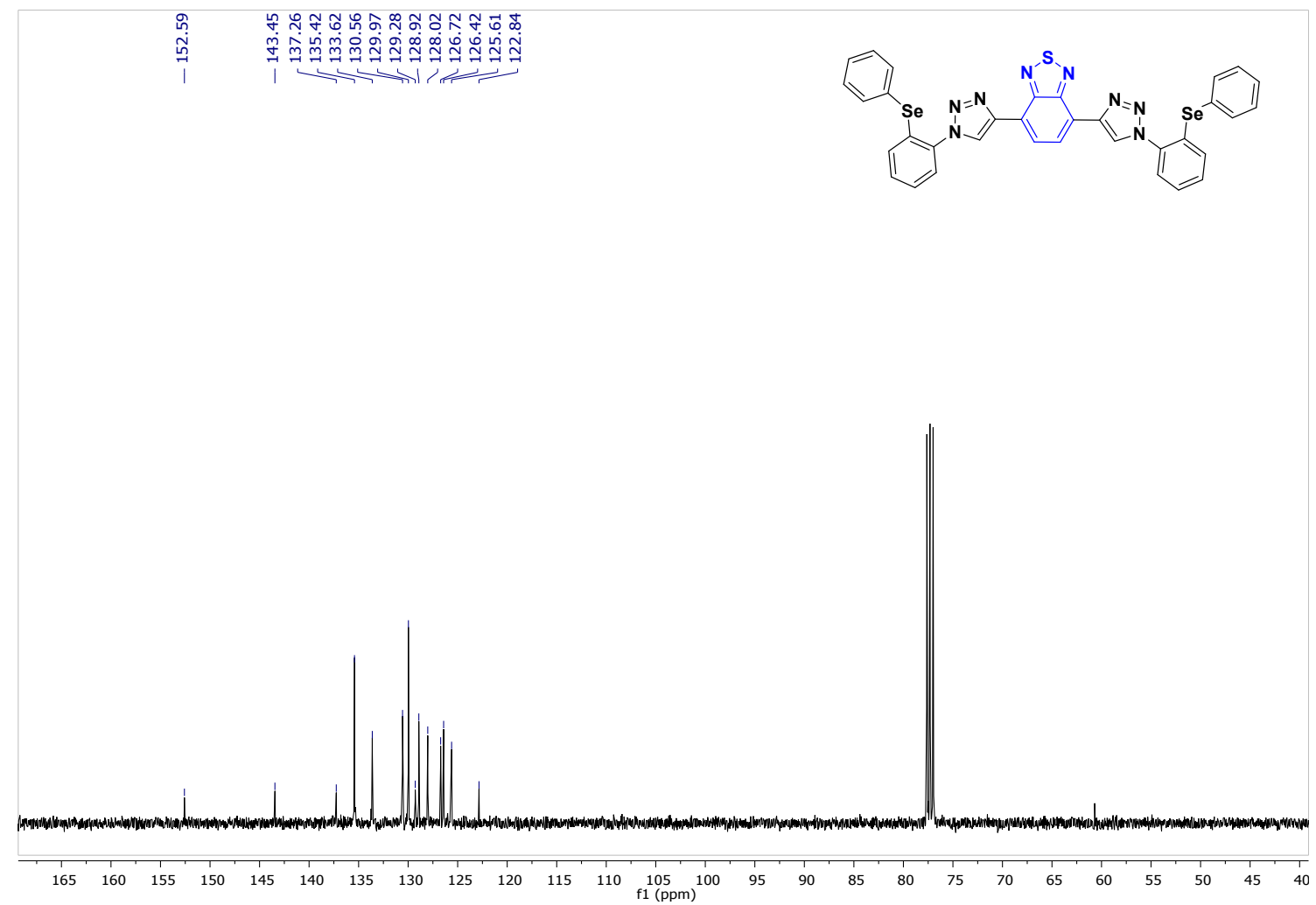

Figure S2. ${ }^{13} \mathrm{C}\left\{{ }^{1} \mathrm{H}\right\} \mathrm{NMR}(100 \mathrm{MHz})$ spectrum for compound $3 \mathbf{a}$ in $\mathrm{CDCl}_{3}$. 


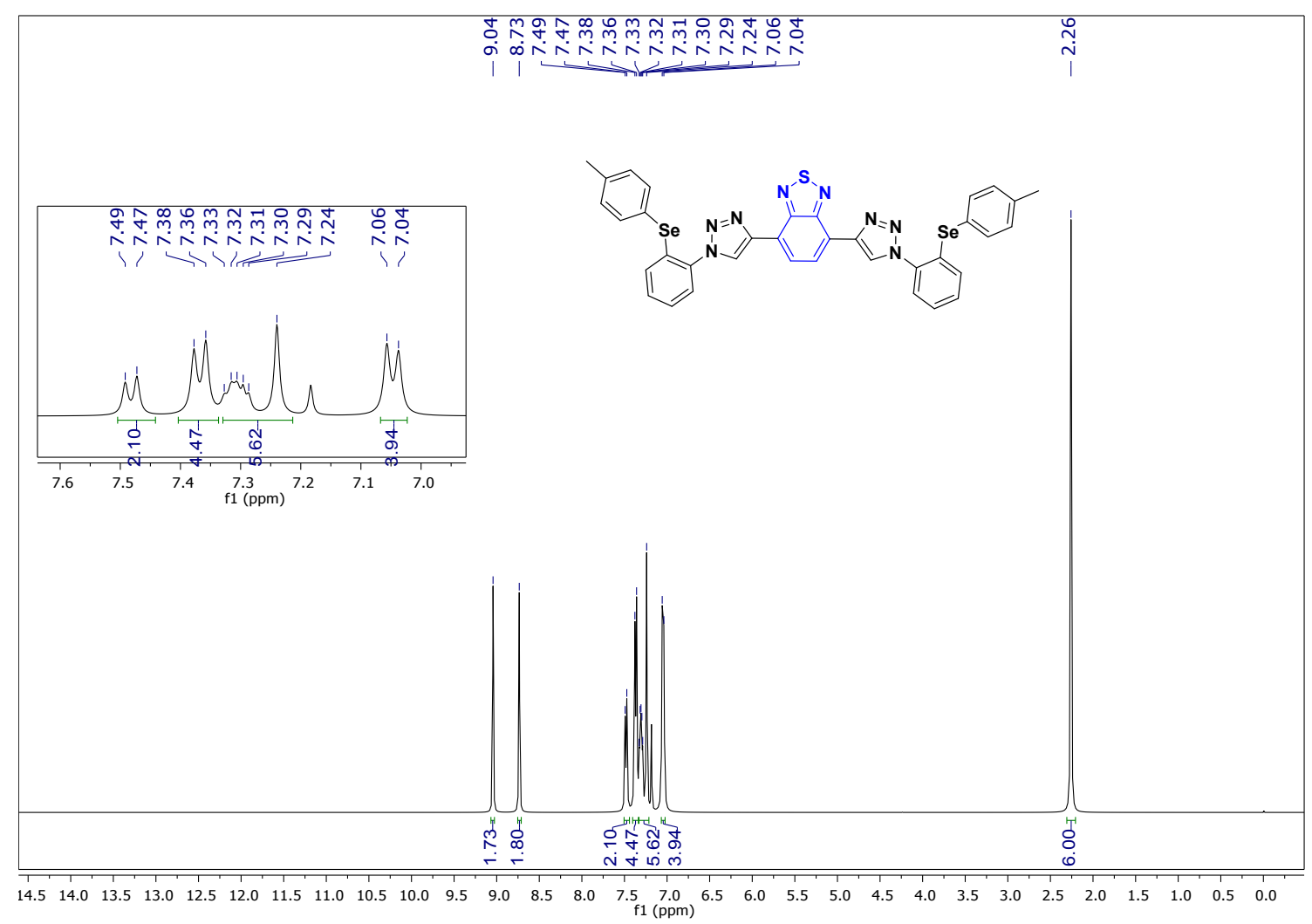

Figure S3. ${ }^{1} \mathrm{H}$ NMR (400 MHz) spectrum for compound $3 \mathbf{b}$ in $\mathrm{CDCl}_{3}$.

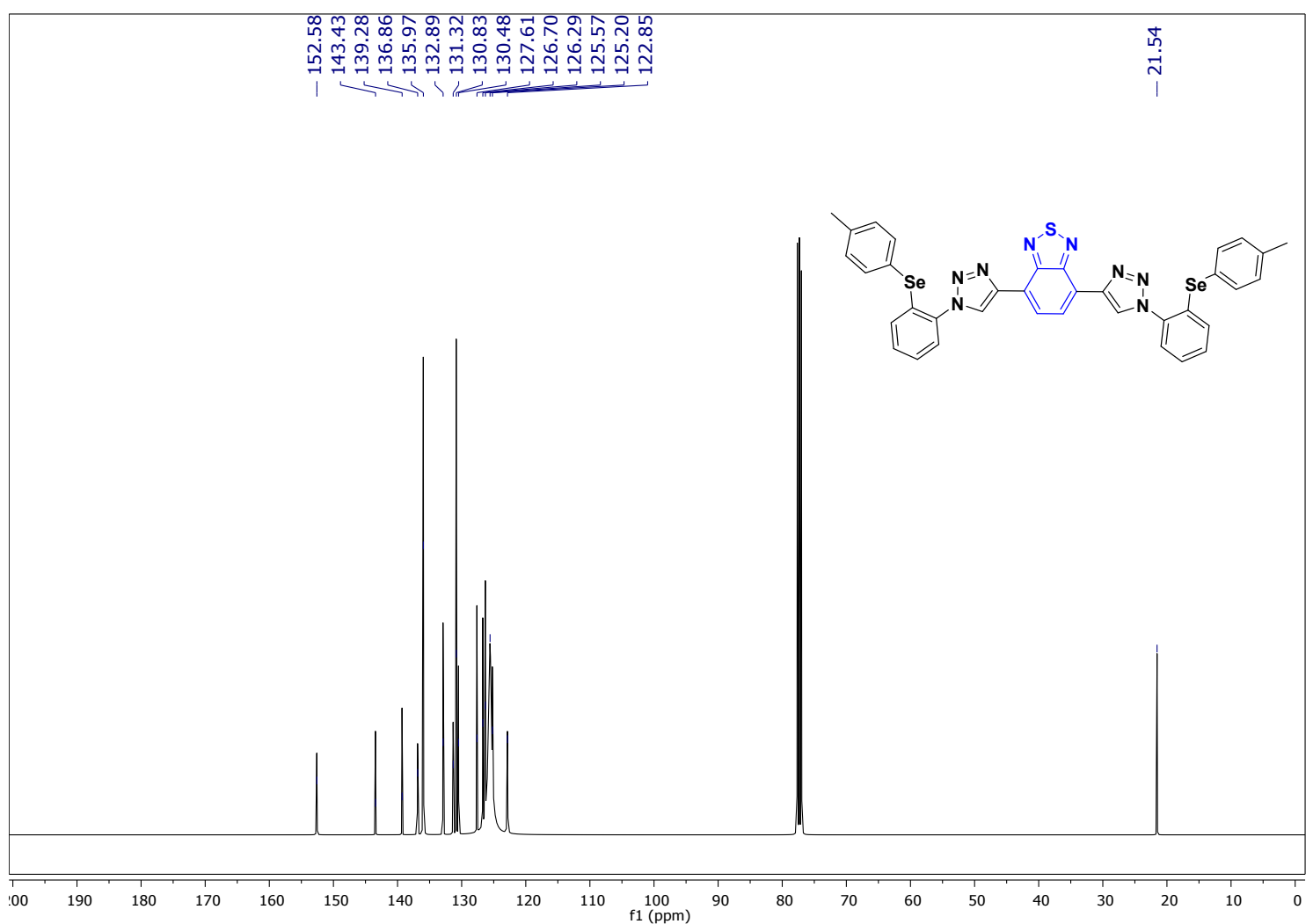

Figure S4. ${ }^{13} \mathrm{C}\left\{{ }^{1} \mathrm{H}\right\}$ NMR (100 MHz) spectrum for compound $\mathbf{3 b}$ in $\mathrm{CDCl}_{3}$. 


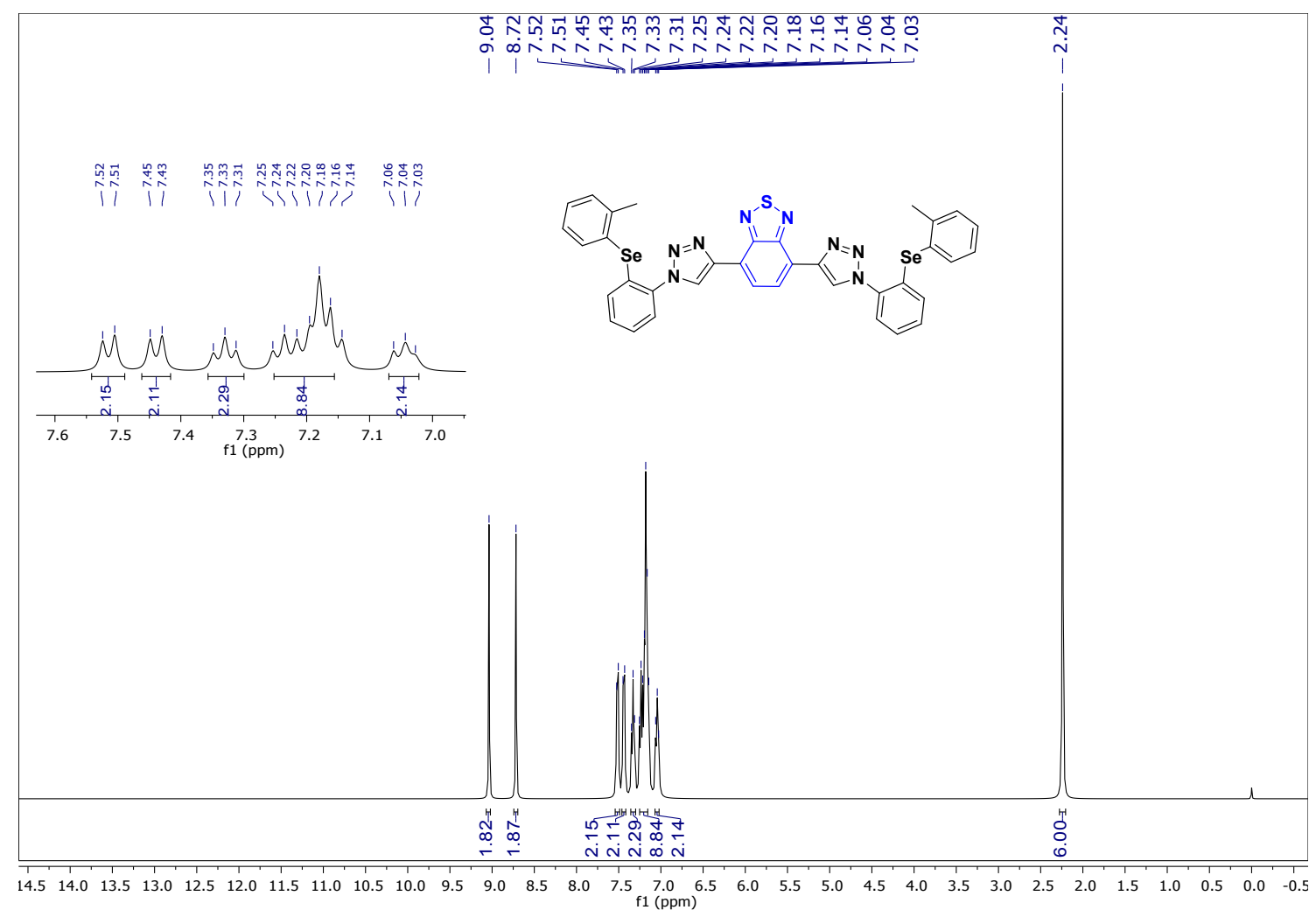

Figure S5. ${ }^{1} \mathrm{H}$ NMR (400 MHz) spectrum for compound $3 \mathrm{c}$ in $\mathrm{CDCl}_{3}$.

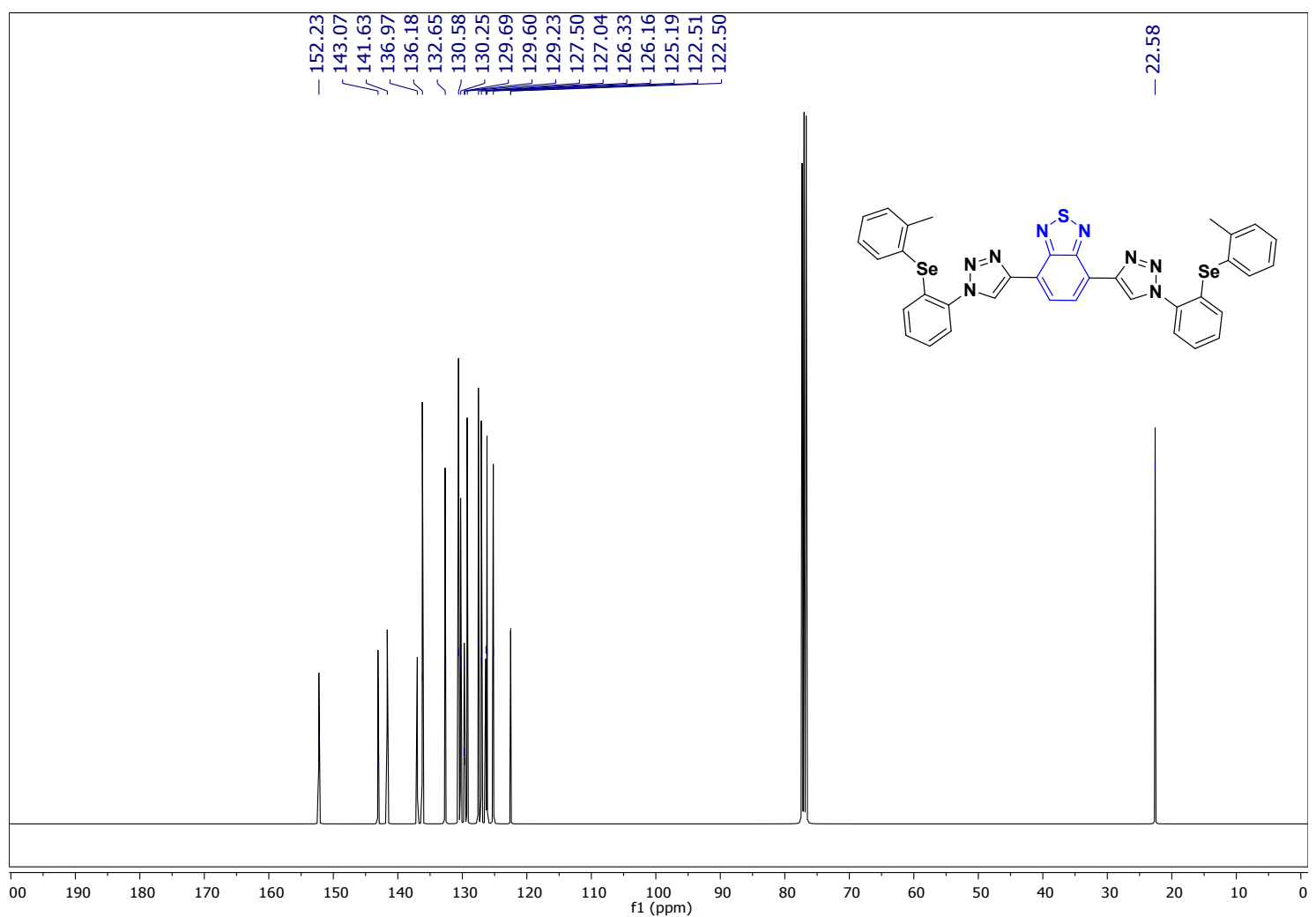

Figure S6. ${ }^{13} \mathrm{C}\left\{{ }^{1} \mathrm{H}\right\}$ NMR (100 MHz) spectrum for compound $3 \mathrm{c}$ in $\mathrm{CDCl}_{3}$. 


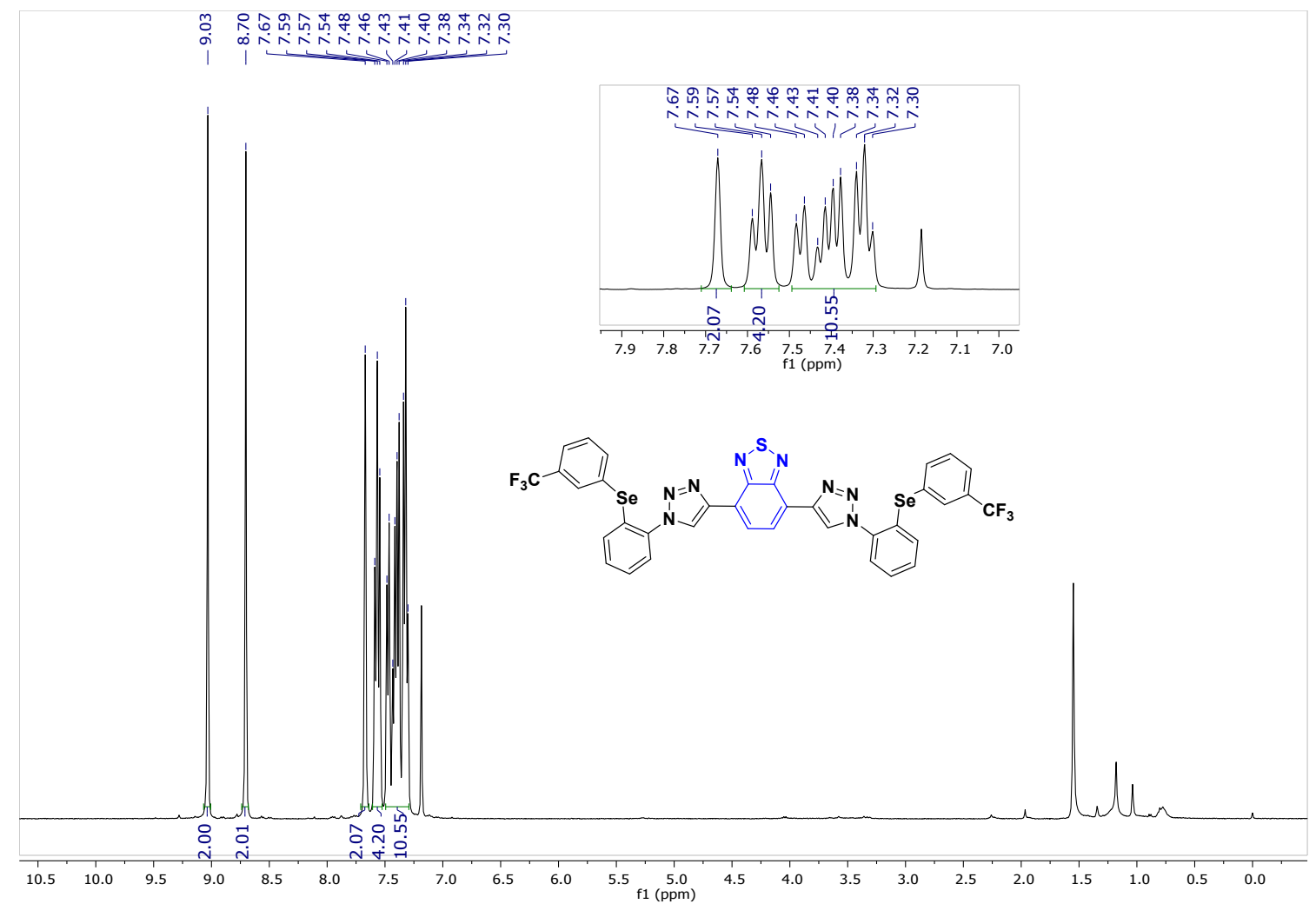

Figure S7. ${ }^{1} \mathrm{H}$ NMR $(400 \mathrm{MHz})$ spectrum for compound $3 \mathrm{~d}$ in $\mathrm{CDCl}_{3}$.

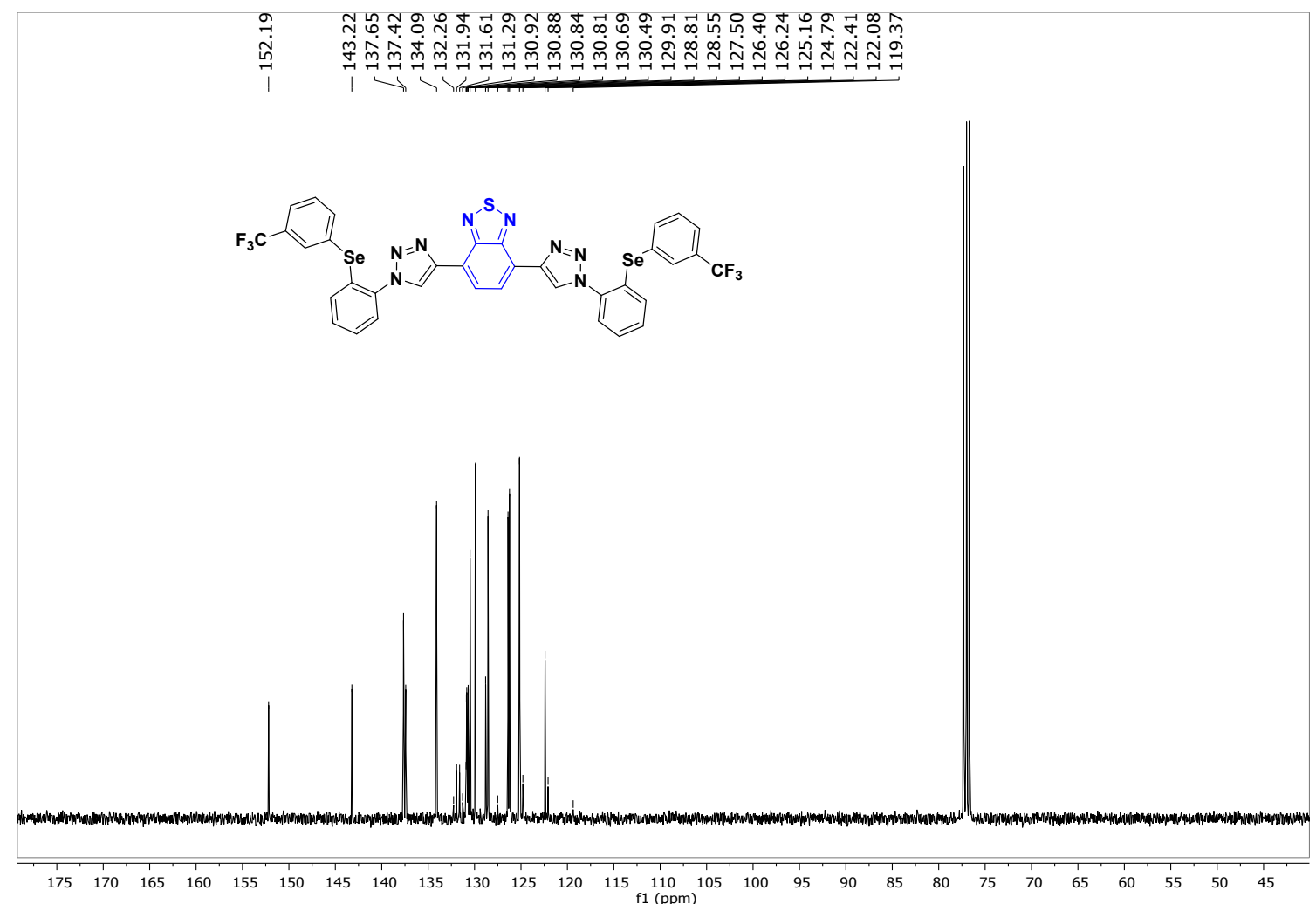

Figure S8. ${ }^{13} \mathrm{C}\left\{{ }^{1} \mathrm{H}\right\}$ NMR $(100 \mathrm{MHz})$ spectrum for compound $\mathbf{3 d}$ in $\mathrm{CDCl}_{3}$. 


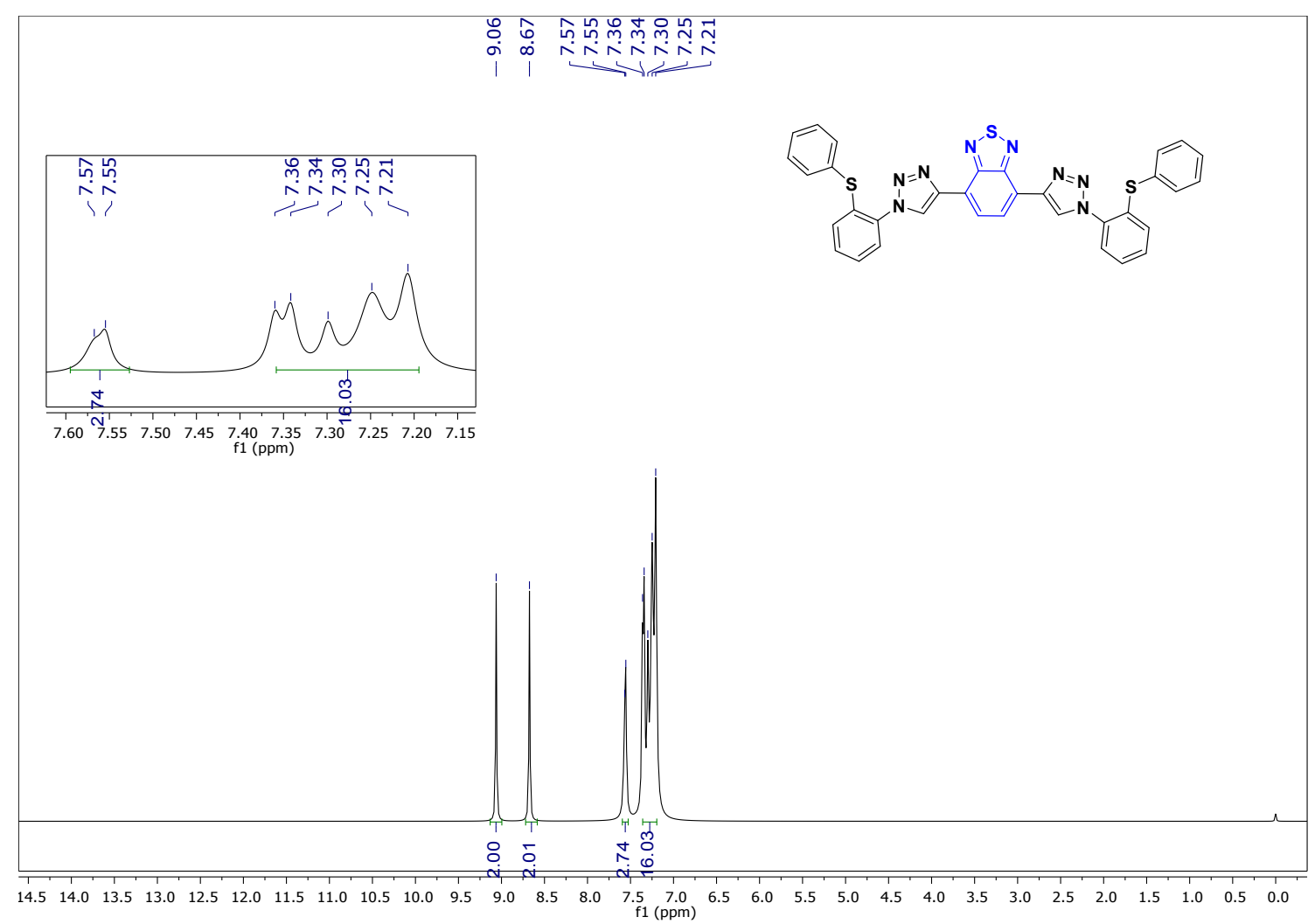

Figure S9. ${ }^{1} \mathrm{H}$ NMR (400 MHz) spectrum for compound $3 \mathbf{e}$ in $\mathrm{CDCl}_{3}$.

กิน

긴 $\quad$
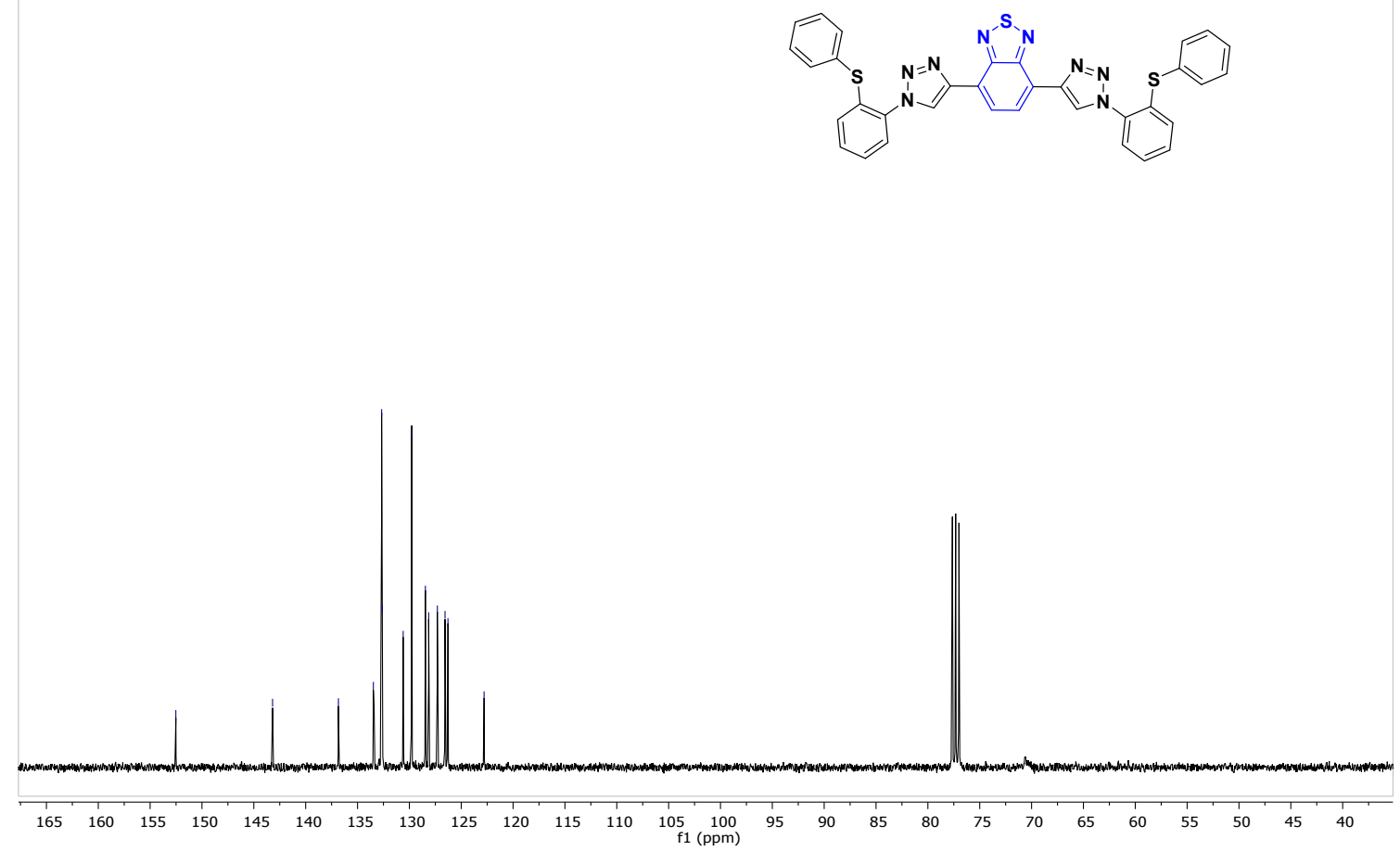

Figure S10. ${ }^{13} \mathrm{C}\left\{{ }^{1} \mathrm{H}\right\}$ NMR $(100 \mathrm{MHz})$ spectrum for compound $3 \mathbf{e}$ in $\mathrm{CDCl}_{3}$. 


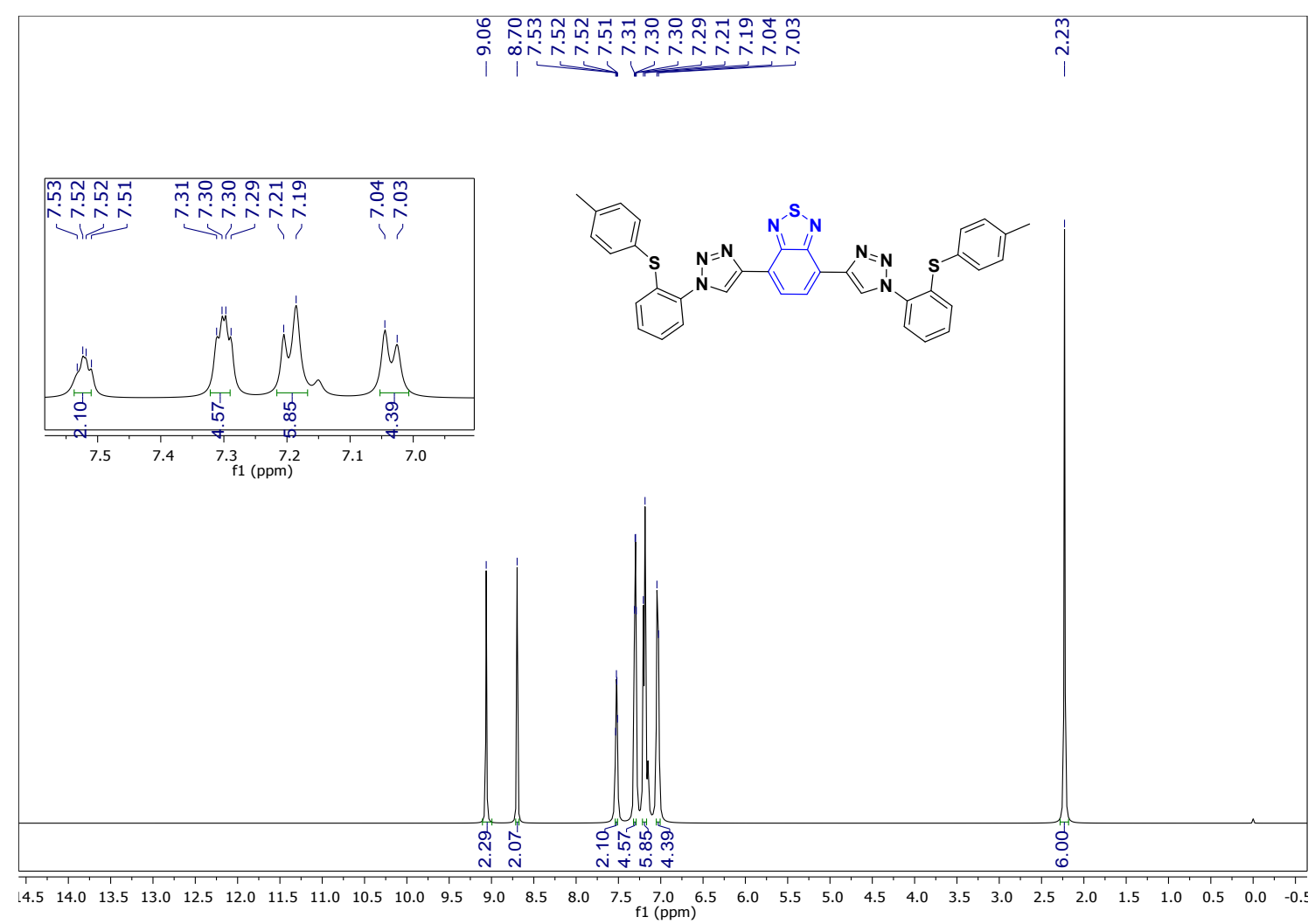

Figure S11. ${ }^{1} \mathrm{H}$ NMR (400 MHz) spectrum for compound $3 f$ in $\mathrm{CDCl}_{3}$.

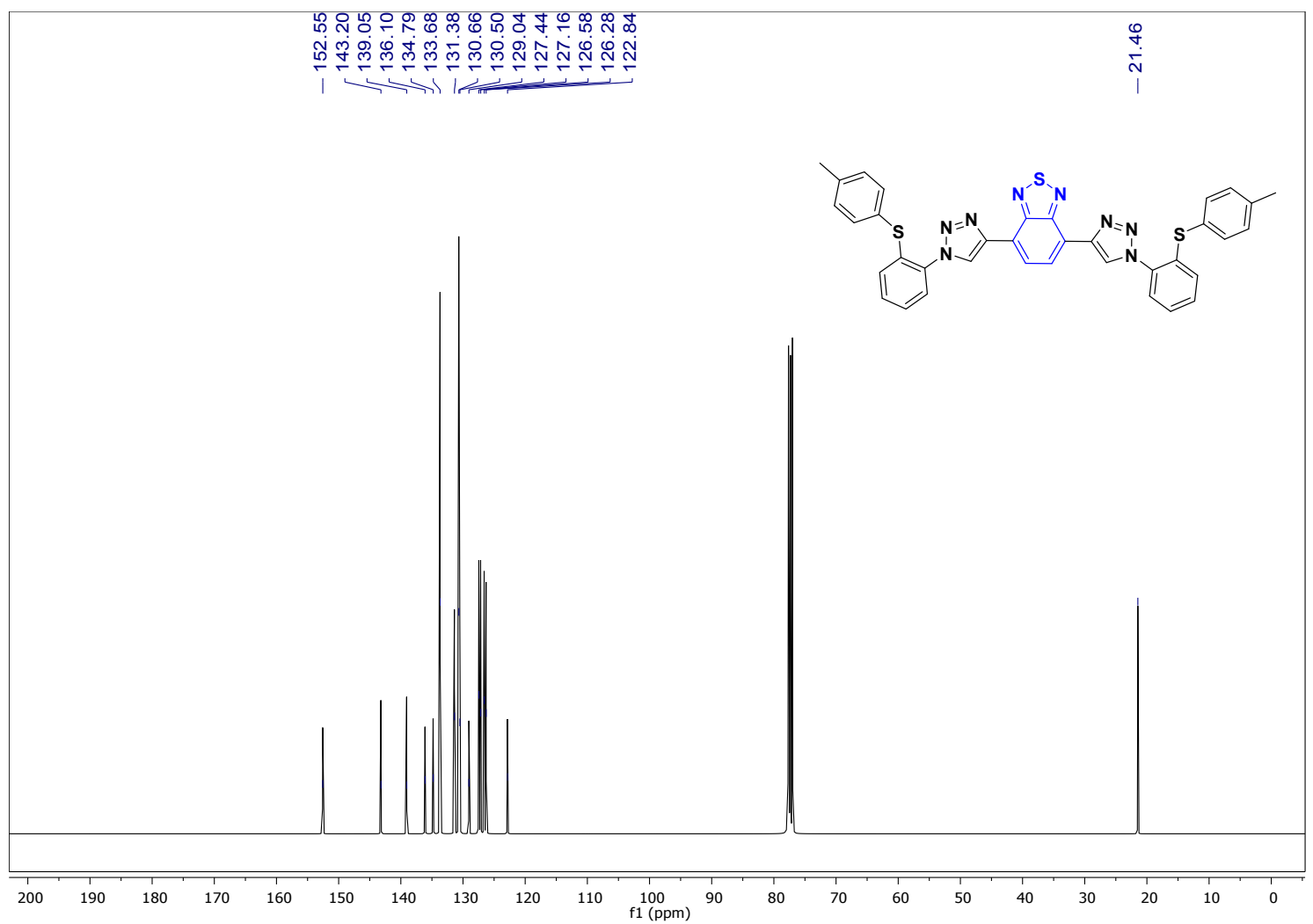

Figure S12. ${ }^{13} \mathrm{C}\left\{{ }^{1} \mathrm{H}\right\} \mathrm{NMR}(100 \mathrm{MHz})$ spectrum for compound $\mathbf{3 f}$ in $\mathrm{CDCl}_{3}$. 


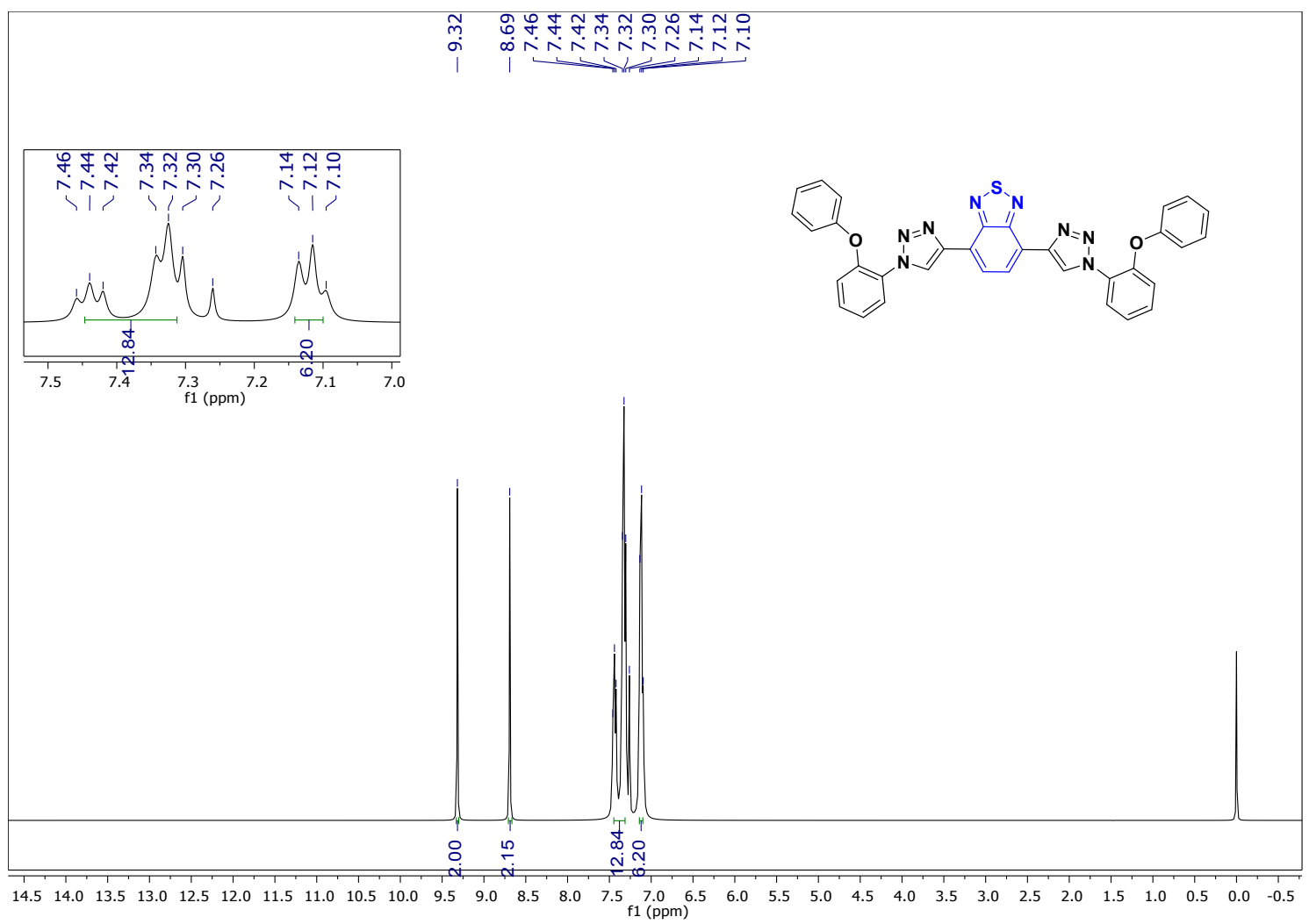

Figure S13. ${ }^{1} \mathrm{H}$ NMR (400 MHz) spectrum for compound $\mathbf{3 g}$ in $\mathrm{CDCl}_{3}$.

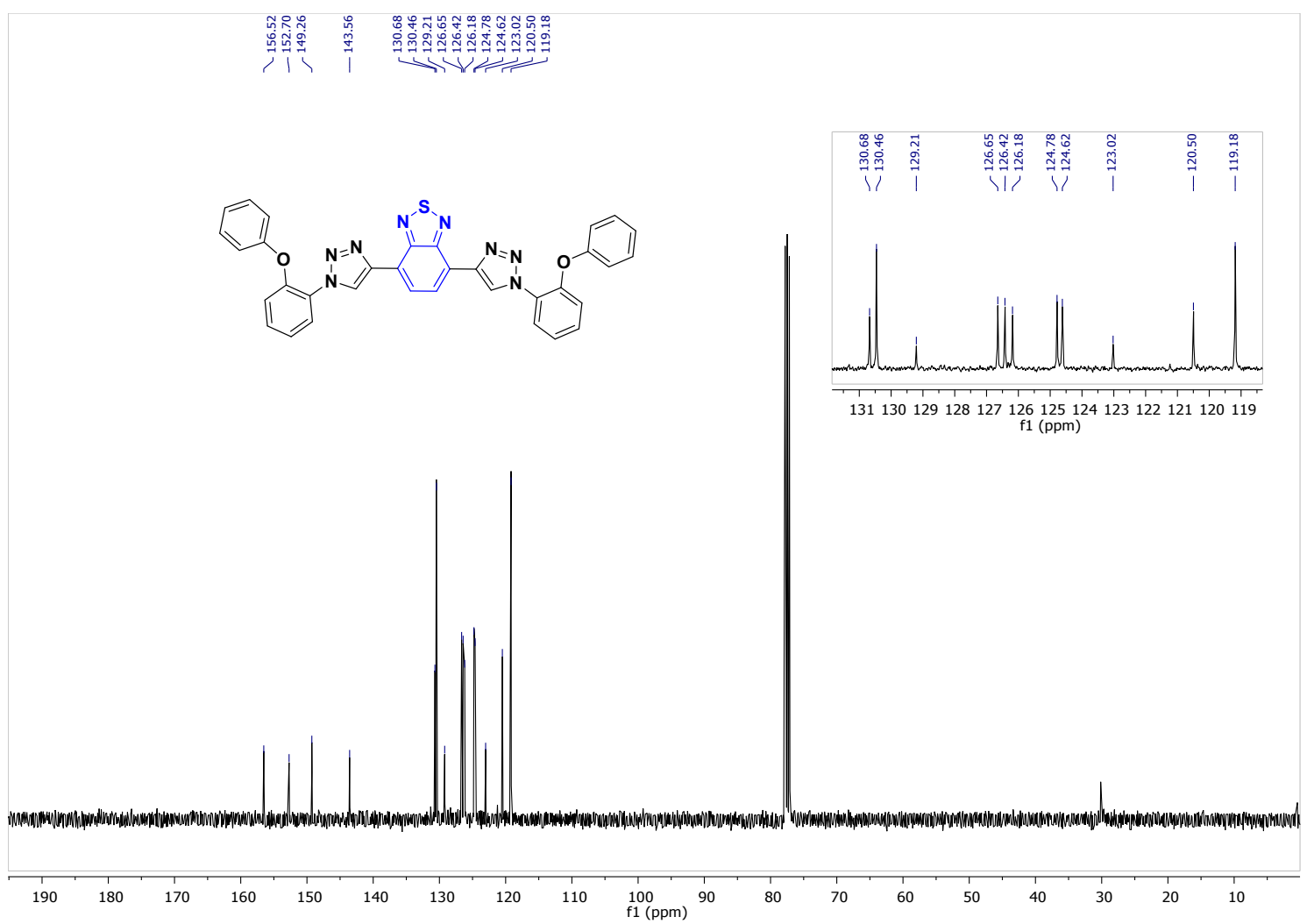

Figure S14. ${ }^{13} \mathrm{C}\left\{{ }^{1} \mathrm{H}\right\}$ NMR $(100 \mathrm{MHz})$ spectrum for compound $\mathbf{3 g}$ in $\mathrm{CDCl}_{3}$. 


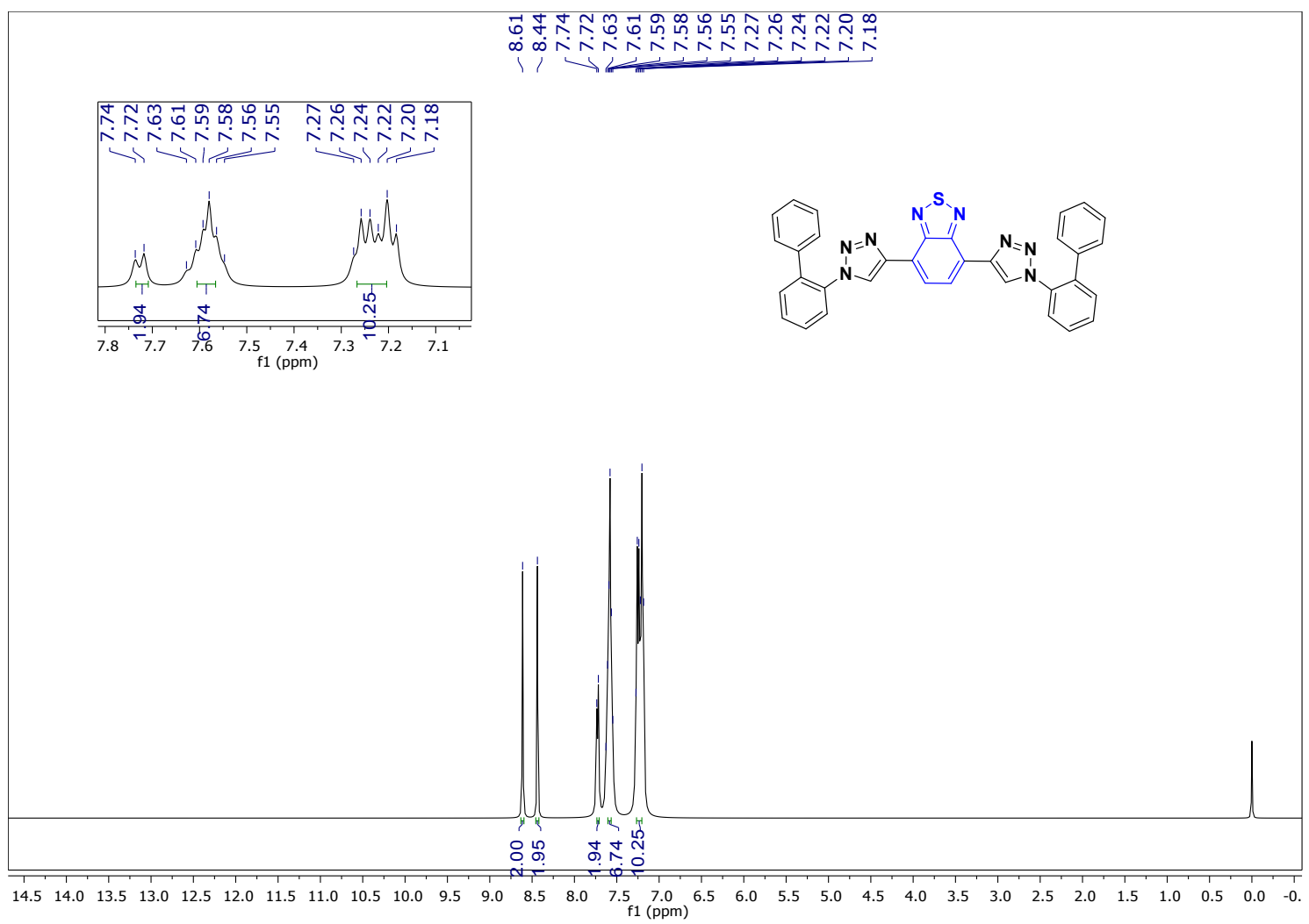

Figure S15. ${ }^{1} \mathrm{H}$ NMR (400 MHz) spectrum for compound $3 \mathbf{h}$ in $\mathrm{CDCl}_{3}$.

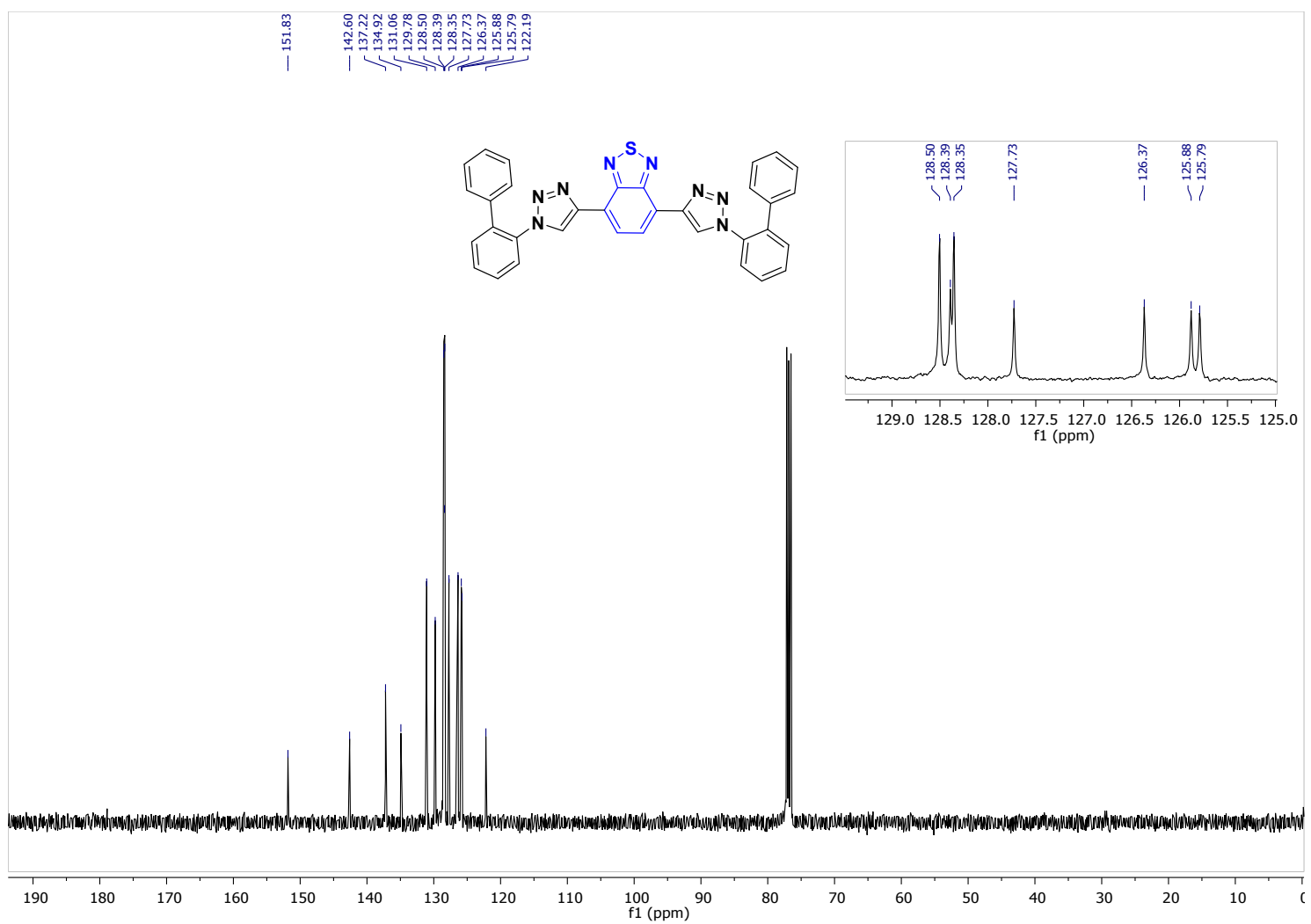

Figure S16. ${ }^{13} \mathrm{C}\left\{{ }^{1} \mathrm{H}\right\}$ NMR $(100 \mathrm{MHz})$ spectrum for compound $\mathbf{3 h}$ in $\mathrm{CDCl}_{3}$. 


\section{Crystal structures of bis-triazolylchalcogenium-BTDs 3}

Through a careful process of controlled evaporation and using $15 \mathrm{mg}$ of compounds in a $10 \mathrm{~mL}$-solution $\left(38-62 \% \mathrm{MeOH} / \mathrm{CH}_{2} \mathrm{Cl}_{2}\right.$ ) at a temperature range of 20 to $25^{\circ} \mathrm{C}$, four crystals were obtained $(\mathbf{3 c}, \mathbf{3 e}, \mathbf{3 f}$, and $\mathbf{3 g}$ ). In all cases, the crystals showed needle morphology. All molecules presented distinct spatial groups $P 21 / c$ (3c), $P-1(3 \mathbf{e}), C 2 / c$ (3f) and $P b c n(3 \mathbf{g})$, which causes four different packing processes to occur. Despite this, all benzothiazole rings present the characteristic planarity having bond distances ranging from 1.602(3) to 1.622(5) $\AA$ (N1-S; N2-S) and 1.332(7) to 1.362(4) $\AA$ (CN) compatible with literature data with molecules containing this class of rings [(1.607(2) to 1.635(11) $\AA$ and 1.329 (16) to $1.635(11) \AA] .^{1}$

Similarly, triazolyl rings have the planarity expected from the hybridization of the nitrogen atoms present, binding distances range from 1.268(6) to $1.379 \AA$ (N-N bonds), $1.328(6)$ to $1.387(7) \AA$ (C-N bonds) and 1.343(8) to 1.370(8) $\AA$ (C$\mathrm{C}$ bonds) are in accordance with literature reports [1.312(3) to 1.361(2) $\AA$ (N-N bonds), $1.353(2)$ to $1.368(2) \AA$ (C-N bonds) and 1.353(2) to $1.367(3) \AA$ (C-C bonds)], respectively. ${ }^{2}$

Although the benzothiazole and triazolyl rings have the expected flatness, (Figure S17), however the substituents directly linked to oxygen, sulfur and selenium atoms, there is a variation perpendicular to the plane, a situation explained by the presence of electrons pairs in the chalcogens atoms, allowing an angular geometry. This geometry presents a modification in the order of the molecules that present the $\mathrm{O}>\mathrm{S}>\mathrm{Se}$ chalcogens, as expected. The same behavior is evidenced in the other molecules. The alteration of the chalcogens and, consequently, the substituents attached to them did not promote substantial change in the bonding distances and angles of the aforementioned rings, as the main bonding angles and distances can be evaluated in the Table S1.

\footnotetext{
${ }^{1}$ (a) Milić, J.; Zalibera, M.; Talaat, D.; Nomrowski, J.; Trapp, N.; Ruhlmann, L.; Boudon, C.; Wenger, O. S.; Savitsky, A.; Lubitz, W.; Diederich, F. Chem.-Eur. J. 2018, 24, 1431-1440; (b) Ams, M. R.; Trapp, N.; Schwab, A.; Milić, J. V.; Diederich, F. Chem.-Eur. J. 2019, 25, 323-333; (c) Amacher, A.; Luo, H.; Liu, Z.; Bircher, M.; Cascella, M.; Hauser, J.; Decurtins, S.; Zhang, D.; Liu, S.-X. RSC Adv. 2014, 4, 2873 2878; (d) Wudarczyk, J.; Papamokos, G.; Marszalek, T.; Nevolianis, T.; Schollmeyer, D.; Pisula, W.; Floudas, G.; Baumgarten, M.; Müllen, K. ACS Appl. Mater. Interfaces 2017, 9, 20527-20535; (e) Satou, M.; Uchinaga, K.; Wakamiya, A.; Murata, Y. Chem. Lett. 2014, 43, 1386-1388; (f) Akhtaruzzaman, Md.; Tomura, M.; Nishida, J.; Yamashita, Y. J. Org. Chem. 2004, 69, 2953-2958.

${ }^{2}$ Mohammed, I.; Kummetha, I. R.; Singh, G.; Sharova, N.; Lichinchi, G.; Dang, J.; Stevenson, M.; Rana, T. M. J. Med. Chem. 2016, 59, 7677-7682.
} 

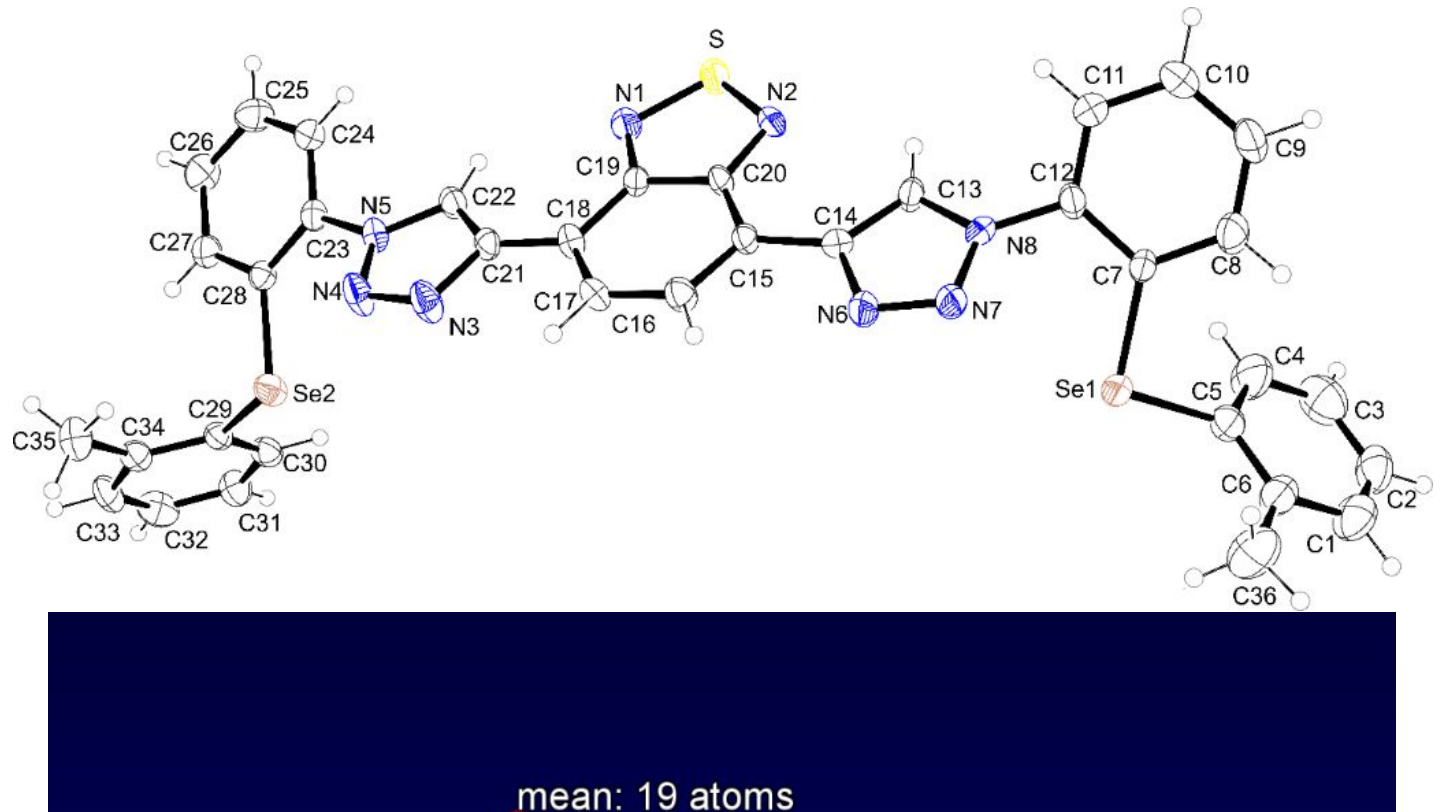

C36

\section{mean: 19 atoms}

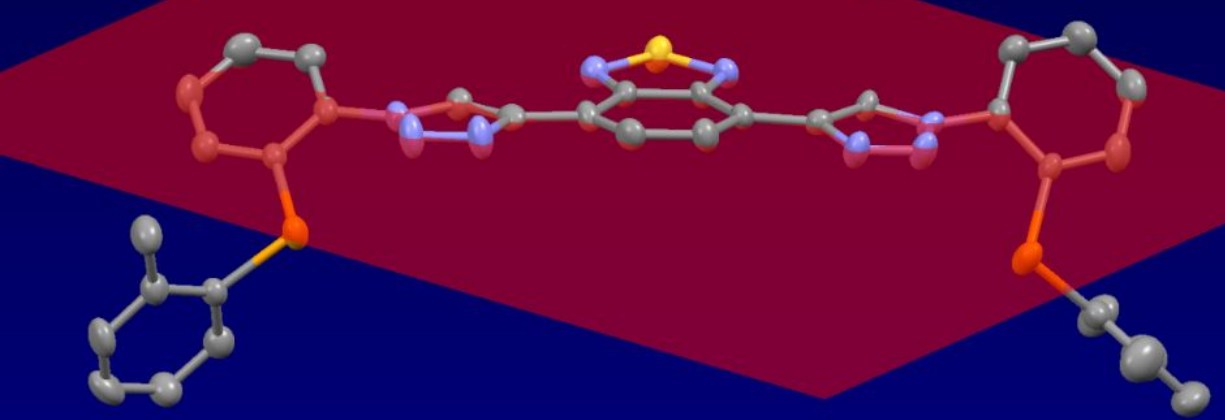

Figure S17. Up: ORTEP representation for the molecule 3c. Thermal ellipsoids with $50 \%$ probability level. Below: Representation of $3 \mathrm{c}$ plane molecule. The benzothiadiazole and 1,2,3-triazolyl rings are in plane, but the chalcogen-bound substituents are perpendicular to the principal plane of the molecule. The solvate $\left(\mathrm{CH}_{2} \mathrm{Cl}_{2}\right)$ was not demonstrated for better visualization. 


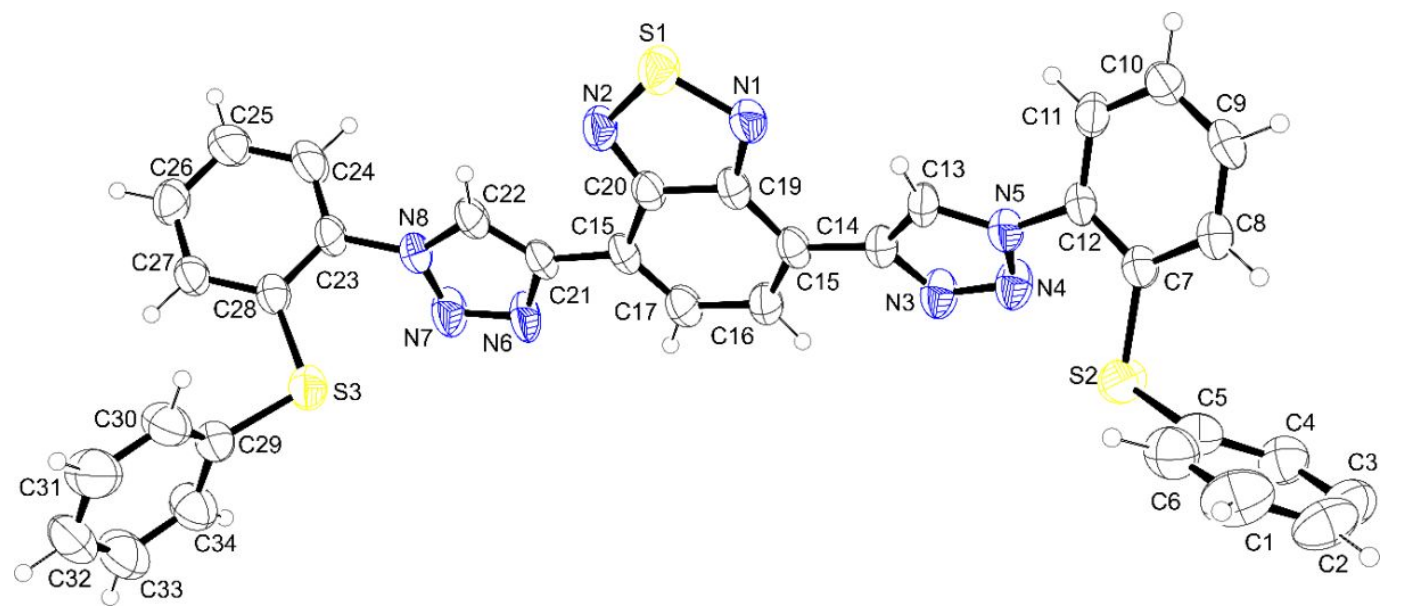

Figure S18. Projection of the molecular structure of the $3 \mathbf{e}$. Thermal ellipsoids with $50 \%$ probability level.

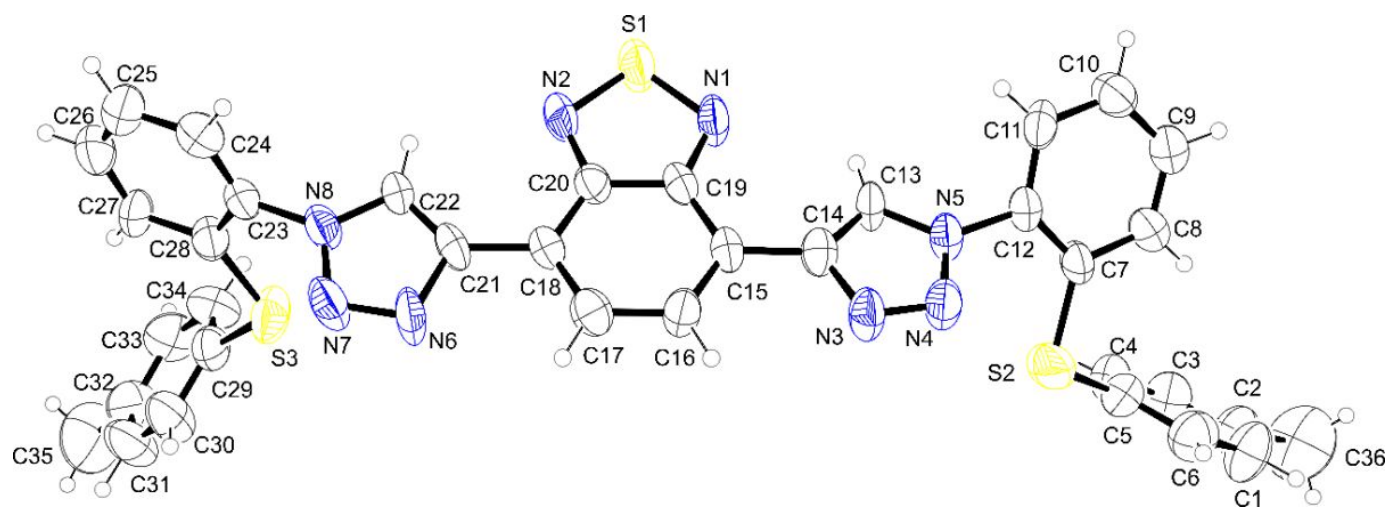

Figure S19. Projection of the molecular structure of the $\mathbf{3 f}$. Thermal ellipsoids with $50 \%$ probability level.

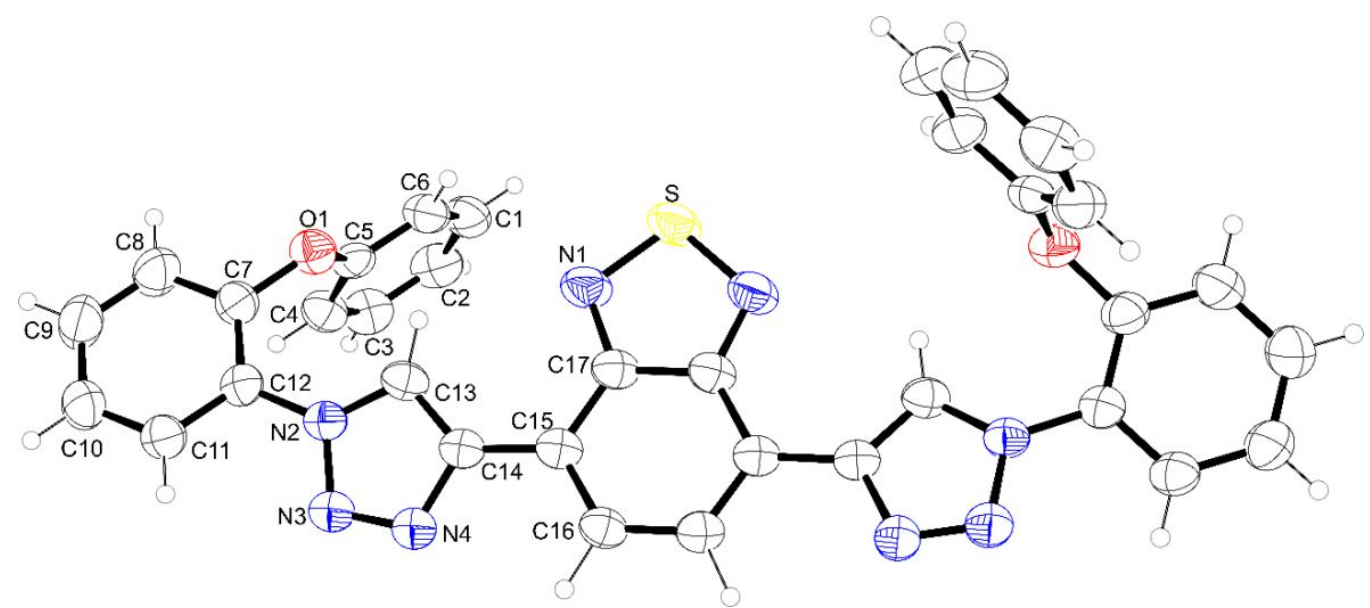

Figure S20. Projection of the molecular structure of the $\mathbf{3 g}$. Thermal ellipsoids with $50 \%$ probability level. 
Table S1. Selected bond lengths $(\AA)$ and angles $\left({ }^{\circ}\right)$ for the compounds $3 \mathbf{c}, \mathbf{3 e}, \mathbf{3 f}$ and $\mathbf{3 g}$.

\begin{tabular}{|c|c|c|c|c|}
\hline Bond & \multicolumn{4}{|c|}{ Compound } \\
\hline Atoms & $3 c$ & $3 e$ & $3 f$ & $3 g$ \\
\hline N1-S & $1.616(5)$ & $1.602(3)$ & $1.622(5)$ & $1.608(2)$ \\
\hline N2-S & $1.608(6)$ & $1.610(3)$ & $1.603(5)$ & * \\
\hline \multicolumn{5}{|l|}{ BTD ring } \\
\hline C20-N2 & $1.346(8)$ & $1.337(5)$ & $1.367(7)$ & $1.349(3)$ \\
\hline C19-N1 & $1.344(8)$ & $1.362(4)$ & $1.332(7)$ & * \\
\hline \multicolumn{5}{|l|}{ BTD ring } \\
\hline C14-N3; C21-N6 & $1.370(6) ; 1.373(8)$ & 1.361(5);1.364(5) & $1.378(7) ; 1.371(7)$ & $1.368(3)$ \\
\hline N3-N4; N6-N7 & $1.303(7) ; 1.308(7)$ & $1.314(4) ; 1.314(4)$ & $1.268(6) ; 1.323(6)$ & $1.302(3)$ \\
\hline N4-N5; N7-N8 & $1.354(7) ; 1.349(7)$ & $1.348(4) ; 1.349(4)$ & $1.379(6) ; 1.361(6)$ & $1.358(2)$ \\
\hline N5-C13; N8-C22 & $1.339(7) ; 1.353(8)$ & $1.340(4) ; 1.347(5)$ & $1.328(6) ; 1.314(6)$ & $1.347(3)$ \\
\hline C13-C14; C22-C21 & $1.370(8) ; 1.366(9)$ & $1.370(5) ; 1.347(5)$ & $1.315(7) ; 1.343(8)$ & $1.362(3)$ \\
\hline 1,2,3-Triazolyl ring & & & & \\
\hline
\end{tabular}

\section{Angles}

\begin{tabular}{|c|c|c|c|c|}
\hline C28-S3-C29 & $\begin{array}{l}---- \\
\end{array}$ & 104.01(18) & $\begin{array}{l}---- \\
\end{array}$ & $\begin{array}{l}---- \\
\end{array}$ \\
\hline C7-S2-C5 & & $100.77(18)$ & & \\
\hline C28-Se-C29 & $99.9(3)$ & ----- & ----- & ----- \\
\hline C7-Se-C5 & $99.3(3)$ & & & \\
\hline C28-S-C29 & ----- & ----- & $103.9(3)$ & ----- \\
\hline C7-S-C5 & & & $100.7(3)$ & \\
\hline C7-01-05 & ----- & ----- & ----- & $116.56(17)$ \\
\hline
\end{tabular}

* Symmetry transformations used to generate equivalent atoms: $\# 1-x+2, y,-z+3 / 2$. 
Table S2. Crystal data and structure refinement for molecules $\mathbf{3 g}, \mathbf{3 c}, \mathbf{3 e}, \mathbf{3 f}$.

\begin{tabular}{|c|c|c|}
\hline Compound & $3 g$ & $3 c$ \\
\hline Empirical formula & $\mathrm{C}_{34} \mathrm{H}_{22} \mathrm{~N}_{8} \mathrm{O}_{2} \mathrm{~S}$ & $\mathrm{C}_{37} \mathrm{H}_{28} \mathrm{Cl}_{2} \mathrm{~N}_{8} \mathrm{SSe}_{2}$ \\
\hline Formula weight & 606.66 & 845.55 \\
\hline Temperature $(\mathrm{K})$ & $297(2)$ & $297(2)$ \\
\hline Wavelength & 0.71073 & 0.71073 \\
\hline Crystal system & Orthorhombic & Monoclinic \\
\hline Space group & Pbcn & P 1 21/c 1 \\
\hline$a(\AA)$ & $7.875(3)$ & $7.7505(9)$ \\
\hline$b(\AA)$ & $14.846(5)$ & $14.6839(17)$ \\
\hline$c(\AA)$ & $24.930(12)$ & $30.928(3)$ \\
\hline$\alpha\left({ }^{\circ}\right)$ & 90 & 90 \\
\hline$\beta\left({ }^{\circ}\right)$ & 90 & $94.139(3)$ \\
\hline$\gamma\left({ }^{\circ}\right)$ & 90 & 90 \\
\hline Volume $\left(\AA^{3}\right)$ & 2914.6(19) & $3510.7(7)$ \\
\hline$z$ & 4 & 4 \\
\hline Calculated density $\left(\mathrm{mg} \cdot \mathrm{m}^{-3}\right)$ & 1.383 & 1.600 \\
\hline Absorp. coefficient $\left(\mathrm{nm}^{-1}\right)$ & 0.159 & 2.359 \\
\hline$F(000)$ & 1253 & 1696 \\
\hline Crystal size $(\mathrm{mm})$ & $0.28 \times 0.23 \times 0.20$ & $0.224 \times 0.101 \times 0.08$ \\
\hline $\begin{array}{l}\text { Theta range for data collection } \\
\qquad\left(^{\circ}\right)\end{array}$ & 2.74 to 26.06 & 2.42 to 26.40 \\
\hline Limiting índices & $-9 \leq h \leq 7,-18 \leq k \leq 18,-30 \leq 1 \leq 30$ & $\begin{array}{c}-9 \leq h \leq 9,-18 \leq k \leq 18,-38 \leq I \leq \\
38\end{array}$ \\
\hline Reflections collected / unique & $37952 / 2886$ & 36017 / 7198 \\
\hline Completeness to theta & $99.8 \%$ & $99.8 \%$ \\
\hline Absorption correction & Semi-empirical from equivalents & Semi-empirical from equivalentes \\
\hline Max. and min. trans. & $0.9699 / 0.9578$ & 0.7454 / 0.6402 \\
\hline Data / restraints / parameters & $2886 / 0 / 204$ & 7189 / 0 / 451 \\
\hline Goodness-of-fit on $F^{2}$ & 1.064 & 1.056 \\
\hline Indice $R_{\text {int }}$ & 0.0961 & 0.1004 \\
\hline $\begin{array}{l}\text { Final } R \text { indices } R_{1} \text { and } w R_{2}[I> \\
\qquad 2 \sigma(I)]\end{array}$ & $0.0533 / 0.1169$ & $0.0752 / 0.1540$ \\
\hline$R$ indices (all data) & $0.0840 / 0.1338$ & $0.1295 / 0.1725$ \\
\hline Largest diff. peak and hole & 0.376 and -0.302 e. $A^{-3}$ & 0.064 and -0.019 e. $A^{-3}$ \\
\hline
\end{tabular}




\begin{tabular}{|c|c|c|}
\hline Compound & $3 e$ & $3 f$ \\
\hline Empirical formula & $\mathrm{C}_{34} \mathrm{H}_{21} \mathrm{~N}_{8} \mathrm{~S}_{3}$ & $\mathrm{C}_{36} \mathrm{H}_{26} \mathrm{~N}_{8} \mathrm{~S}_{3}$ \\
\hline Formula weight & 337.77 & 666.83 \\
\hline Temperature $(\mathrm{K})$ & $297(2)$ & $297(2)$ \\
\hline Wavelength & 0.71073 & 0.71073 \\
\hline Crystal system & Triclinic & Monoclinic \\
\hline Space group & $P-1$ & C $12 / \mathrm{c} 1$ \\
\hline$a(\AA)$ & $9.4116(9)$ & $33.589(6)$ \\
\hline$b(\AA)$ & $12.2845(13)$ & $10.1323(16)$ \\
\hline$c(\AA)$ & $16.0785(17)$ & $24.032(5)$ \\
\hline$\alpha\left({ }^{\circ}\right)$ & $103.909(4)$ & 90 \\
\hline$\beta\left({ }^{\circ}\right)$ & 102.394(3) & $115.648(8)$ \\
\hline$\gamma\left({ }^{\circ}\right)$ & $96.843(4)$ & 90 \\
\hline Volume $\left(\AA^{3}\right)$ & $1733.6(3)$ & $7373(2)$ \\
\hline$Z$ & 2 & 8 \\
\hline Calculated density $\left(\mathrm{mg} \cdot \mathrm{m}^{-3}\right)$ & 0.249 & 1.201 \\
\hline Absorp. coefficient $\left(\mathrm{nm}^{-1}\right)$ & 0.249 & 0.237 \\
\hline$F(000)$ & 658 & 2768 \\
\hline Crystal size (mm) & $0.26 \times 0.20 \times 0.17$ & $0.20 \times 0.19 \times 0.15$ \\
\hline $\begin{array}{l}\text { Theta range for data collection } \\
\qquad\left(^{\circ}\right)\end{array}$ & 2.25 to 28.07 & 2.20 to 26.89 \\
\hline Limiting índices & $\begin{array}{c}-12 \leq h \leq 10,-16 \leq k \leq 16,-21 \leq I \leq \\
21\end{array}$ & $\begin{array}{c}-42 \leq h \leq 42,-12 \leq k \leq 12,-30 \leq I \leq \\
30\end{array}$ \\
\hline Reflections collected / unique & $22346 / 8428$ & $51006 / 7945$ \\
\hline Completeness to theta & $99.7 \%$ & $99.7 \%$ \\
\hline Absorption correction & Semi-empirical from equivalents & Semi-empirical from equivalents \\
\hline Max. and min. trans. & $0.9689 / 0.9481$ & $0.9753 / 0.9642$ \\
\hline Data / restraints / parameters & $8428 / 0 / 406$ & $7945 / 0 / 424$ \\
\hline Goodness-of-fit on $F^{2}$ & 0.829 & 0.904 \\
\hline Indice $R_{\text {int }}$ & 0.0688 & 0.1800 \\
\hline $\begin{array}{l}\text { Final } \mathrm{R} \text { indices } R_{1} \text { and } w R_{2}[I> \\
\qquad 2 \sigma(I)]\end{array}$ & $0.0714 / 0.1905$ & $0.0965 / 0.1516$ \\
\hline$R$ indices (all data) & $0.1923 / 0.2410$ & $0.1913 / 0.1999$ \\
\hline Largest diff. peak and hole & 0.478 and -0.219 e. $A^{-3}$ & 0.363 and -0.379 e. $A^{-3}$ \\
\hline
\end{tabular}




\section{Electrochemical behavior of bis-triazolylchalcogenium-BTDs 3}

Redox properties by cyclic voltammetry (CV) of compounds 3 in DCM solution was performed (Figure S21). In general, compounds 3 displayed irreversible processes $\left(E_{\mathrm{pa}}\right.$ peaks) between +0.35 to $+0.95 \mathrm{~V}$ range versus ferrocenium/ferrocene redox pair (Table S3). The anodic oxidation observed in all compounds is probably to the formation of an intermediate radical $\pi$-cation specie in air, which was possible by forming the chalcogenide species $(X=O ; X$ is Se or S) (Table S3). ${ }^{3}$ As example, the HOMO-LUMO energy diagram of derivatives $\mathbf{3 a}$ (Se atom), $\mathbf{3 e}$ ( $\mathrm{S}$ atom), $\mathbf{3 g}$ (O atom) and $\mathbf{3 h}$ (only $\mathrm{C}$ atom) are presented in the Figure $\mathrm{S} 22$.

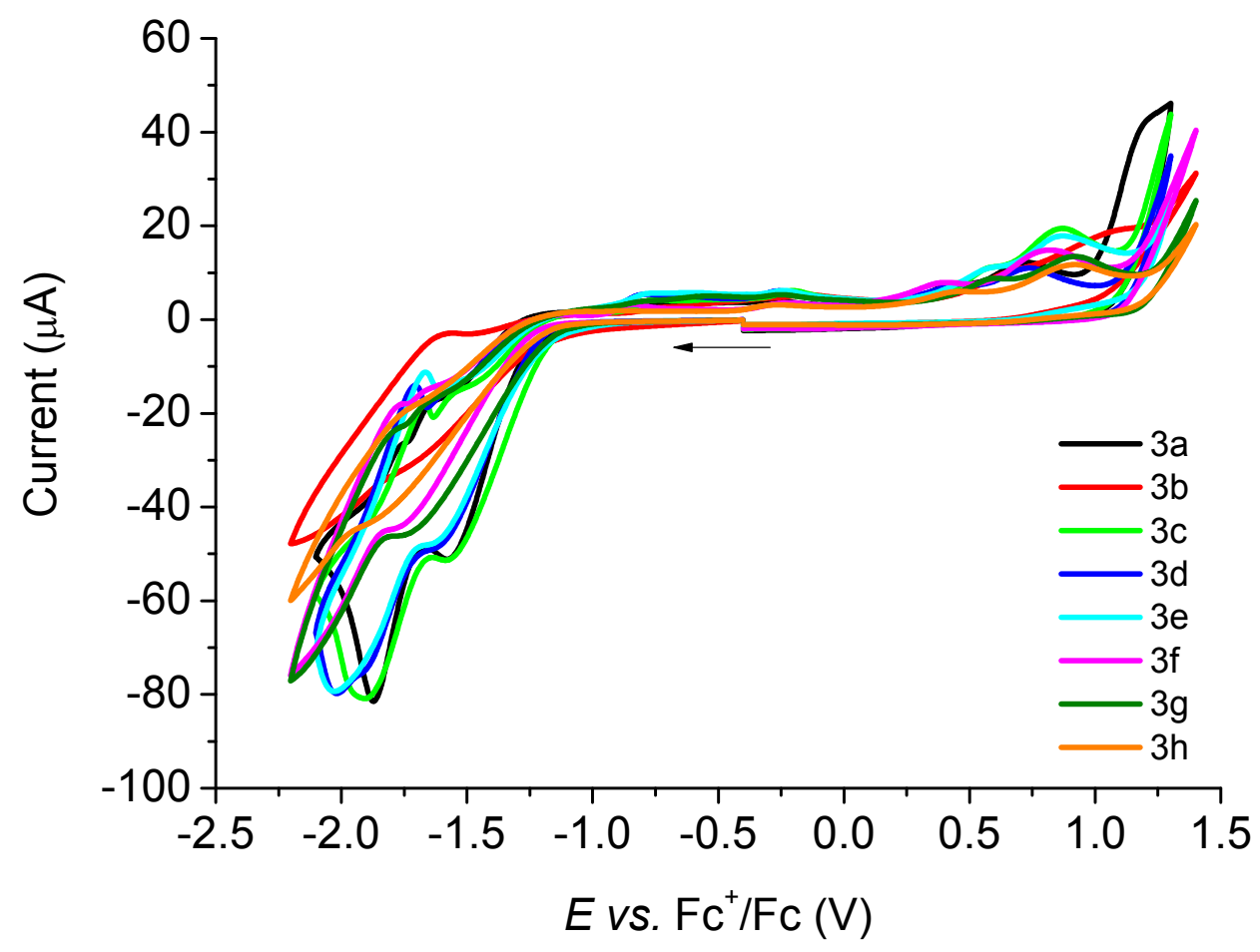

Figure S21. Cyclic voltammogram of compounds in dry DCM containing $0.1 \mathrm{M}$ $\mathrm{TBAPF}_{6}$ as a supporting electrolyte, using a scan rate of $100 \mathrm{mV} \mathrm{s}^{-1}$.

${ }^{3}$ (a) Krüger, R.; Iepsen, B.; Larroza, A. M. E.; Fronza, M. G.; Silveira, C. H.; Bevilacqua, A. C.; Köhler, M. H.; Piquini, P. C.; Lenardão, E. J.; Savegnago, L.; Iglesias, B. A.; Alves, D. Eur. J. Org. Chem. 2020, 3, 348-361; (b) Balaguez, R. A.; Krüger, R.; Iepsen, B.; Schumacher, R. F.; Oliboni, R. S.; Barcellos, T.; Junqueira, H. C.; Baptista, M. S.; Iglesias, B. A.; Alves, D. Eur. J. Org. Chem. 2018, 46, 6507-6514. 


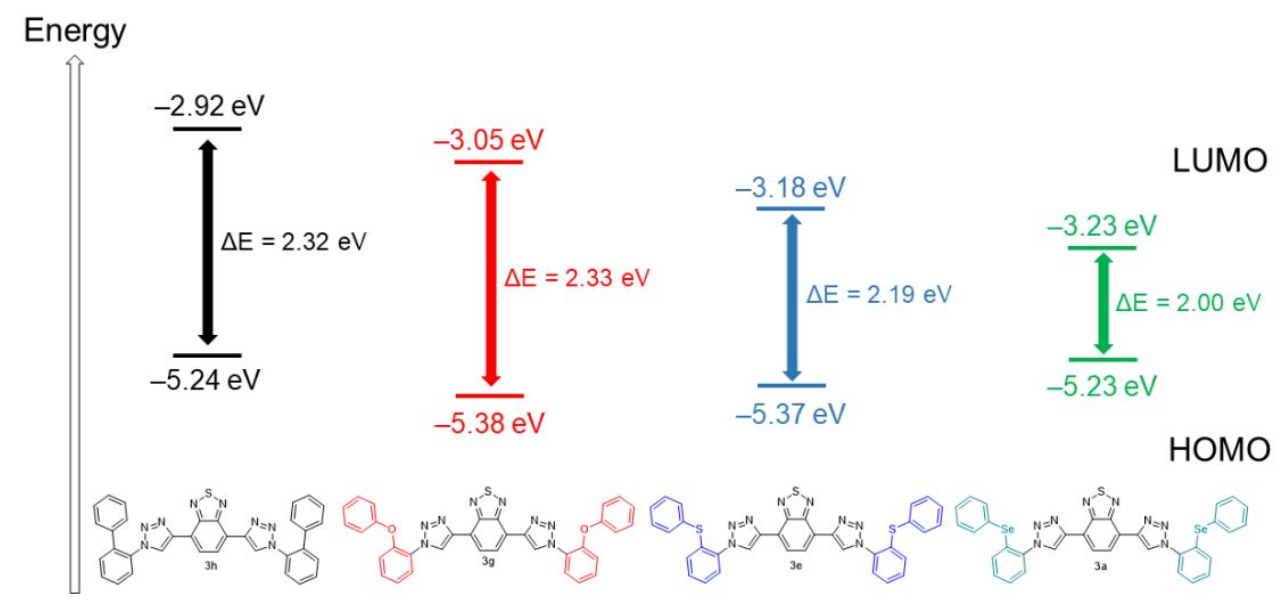

Figure S22. Comparative HOMO-LUMO energy levels of compounds $\mathbf{3 a}, \mathbf{3 e}, \mathbf{3 g}$ and $3 \mathrm{~h}$ using TBAPF6 as the supporting electrolyte and scan rate of $100 \mathrm{mV} \mathrm{s}^{-1}$.

In the cathodic potential range, bis-triazolylchalcogenium-BTDs 3 presents irreversible processes ( $E_{\mathrm{pc}}$ peaks) at the -1.50 to $-2.05 \mathrm{~V}$ region (Table S3). The cathodic redox peaks observed in these bis-triazolyl derivatives can be probably assigned to the $\pi$-radical species of bis-triazolyl compounds stabilized in solution. In comparison to data already published in the literature by Balaguez, ${ }^{3 b}$ Krüger, ${ }^{3 a}$ Silveira and co-workers, ${ }^{4}$ bis-triazolyl derivatives 3 have re-oxidation and reduction processes very similar to other BTD derivatives, as well as approximate values of potentials redox.

Table S3. Electrochemical data by cyclic voltammetry of derivatives $\mathbf{3 a - 3 h}$ in dry DCM solution.

\begin{tabular}{|c|c|c|c|c|c|c|c|}
\hline Compound & $E_{\text {red }}$ & $E_{\text {red }}$ & $E_{\text {oxid }}$ & $E_{\text {oxid }}$ & $E_{\text {LUMo }}(e V)^{d}$ & $\mathrm{E}_{\text {номо }}(\mathrm{eV})^{\mathrm{e}}$ & $\Delta \mathrm{E}^{\mathrm{f}}$ \\
\hline $3 a$ & $-1.57 \mathrm{~V}^{\mathrm{a}}$ & $-1.87 \mathrm{Va}^{\mathrm{a}}$ & $+0.43 \mathrm{~V}^{b}$ & $+0.72 \mathrm{~V}^{b}$ & -3.23 & -5.23 & 2.00 \\
\hline $3 b$ & $-1.60 \mathrm{~V}^{\mathrm{a}}$ & ----- & $+0.64 \mathrm{~V}^{\mathrm{b}}$ & $+1.02 \mathrm{~V}^{\mathrm{b}}$ & -3.20 & -5.44 & 2.24 \\
\hline $3 c$ & $-1.57 \mathrm{~V}^{\mathrm{a}}$ & $-1.91 \mathrm{Va}^{\mathrm{a}}$ & $+0.56 \mathrm{~V}^{\mathrm{b}}$ & $+0.87 \mathrm{~V}^{\mathrm{b}}$ & -3.23 & -5.36 & 2.13 \\
\hline $3 d$ & $-1.61 \mathrm{Va}$ & $-2.02 \mathrm{Va}^{\mathrm{a}}$ & $+0.45 \mathrm{Vb}^{\mathrm{b}}$ & $+0.74 \mathrm{Vb}^{\mathrm{b}}$ & -3.19 & -5.25 & 2.06 \\
\hline $3 e$ & $-1.62 \mathrm{~V}^{\mathrm{a}}$ & $-2.03 \mathrm{~V}^{\mathrm{a}}$ & $+0.57 \mathrm{~V}^{\mathrm{b}}$ & $+0.86 \mathrm{~V}^{\mathrm{b}}$ & -3.18 & -5.37 & 2.19 \\
\hline $3 f$ & $-1.78 \mathrm{~V}^{\mathrm{a}}$ & ----- & $+0.39 \mathrm{~V}^{\mathrm{b}}$ & $+0.81 \mathrm{~V}^{\mathrm{b}}$ & -3.02 & -5.19 & 2.17 \\
\hline $3 g$ & $-1.75 \mathrm{~V}^{\mathrm{a}}$ & ----- & $+0.58 \mathrm{~V}^{\mathrm{b}}$ & $+0.91 \mathrm{~V}^{\mathrm{b}}$ & -3.05 & -5.38 & 2.33 \\
\hline $3 h$ & $-1.88 V^{a}$ & ----- & $+0.44 \mathrm{~V}^{\mathrm{b}}$ & $+0.91 \mathrm{~V}^{b}$ & -2.92 & -5.24 & 2.32 \\
\hline
\end{tabular}

${ }^{\mathrm{a}} E_{\mathrm{pc}}=$ Cathodic peak, ${ }^{\mathrm{b}} E_{\mathrm{pa}}=$ Anodic peak, ${ }^{\mathrm{c}} E_{1 / 2}=E_{\mathrm{pa}}+E_{\mathrm{pc}} / 2,{ }^{\mathrm{d}} E_{\mathrm{LUMO}}=-\left[4.8+E_{\mathrm{red}}(\right.$ versus Fc $\left./ \mathrm{Fc})\right],{ }^{\mathrm{e}} E_{\mathrm{HOMO}}=-\left[4.8+E_{\mathrm{oxid}}\right.$ (versus $\mathrm{FC}^{+} / \mathrm{FC}$ )], ${ }^{\mathrm{f}} \Delta \mathrm{E}=\mathrm{E}_{\mathrm{LUMO}}-\mathrm{E}_{\mathrm{HOMO}},{ }^{*} \mathrm{FC}^{+} / \mathrm{Fc}$ redox couple pair in $\mathrm{DCM}-\mathrm{E}_{1 / 2}=0.4 \mathrm{~V}$;

${ }^{4}$ Silveira, C. H.; Fronza, M. G.; Balaguez, R. A.; Larroza, A. M. E.; Savegnago, L.; Back, D. F.; Iglesias, B. A.; Alves, D. Dyes Pigments 2021, 185, 108910. 


\section{Supplementary Figures}

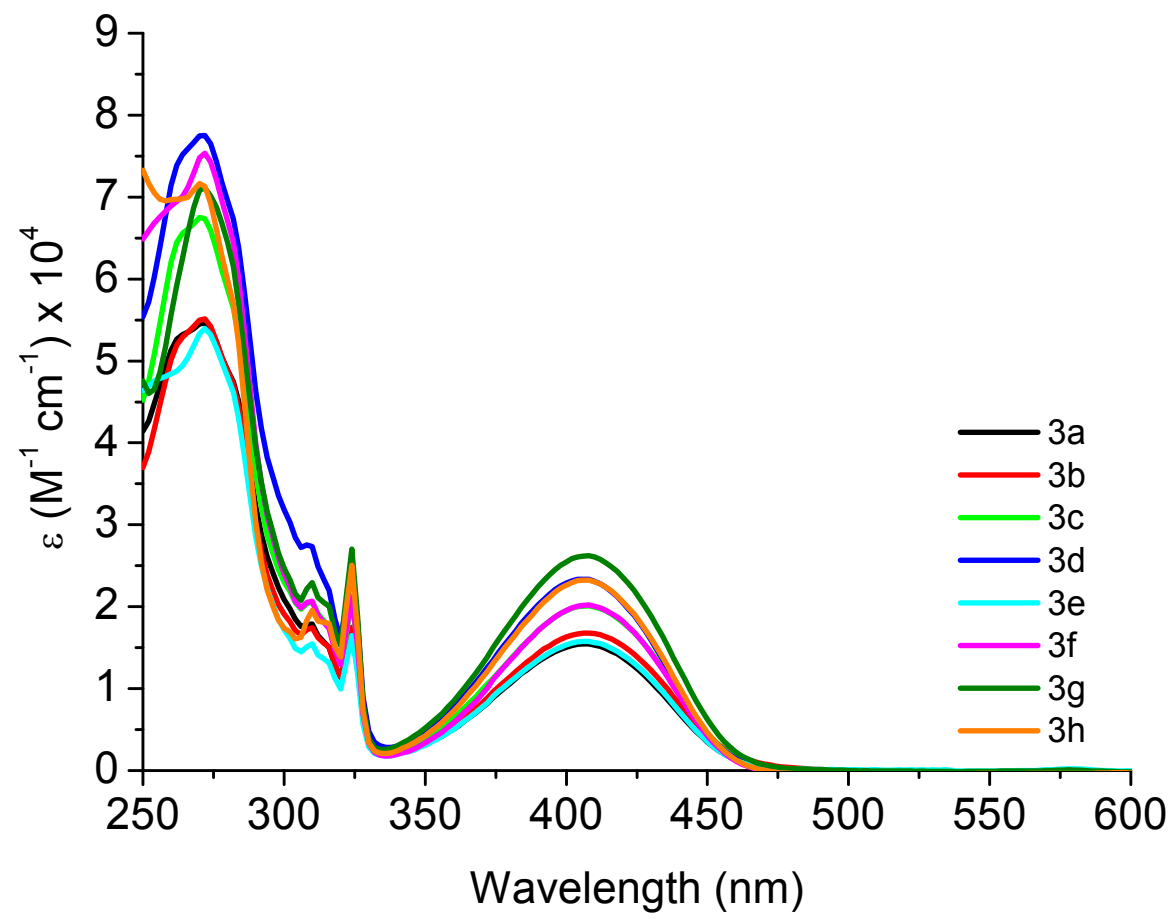

Figure S23. UV-Vis absorption spectra of derivatives in DCM ([ ] = 10-5 $\mathrm{M}$ range).

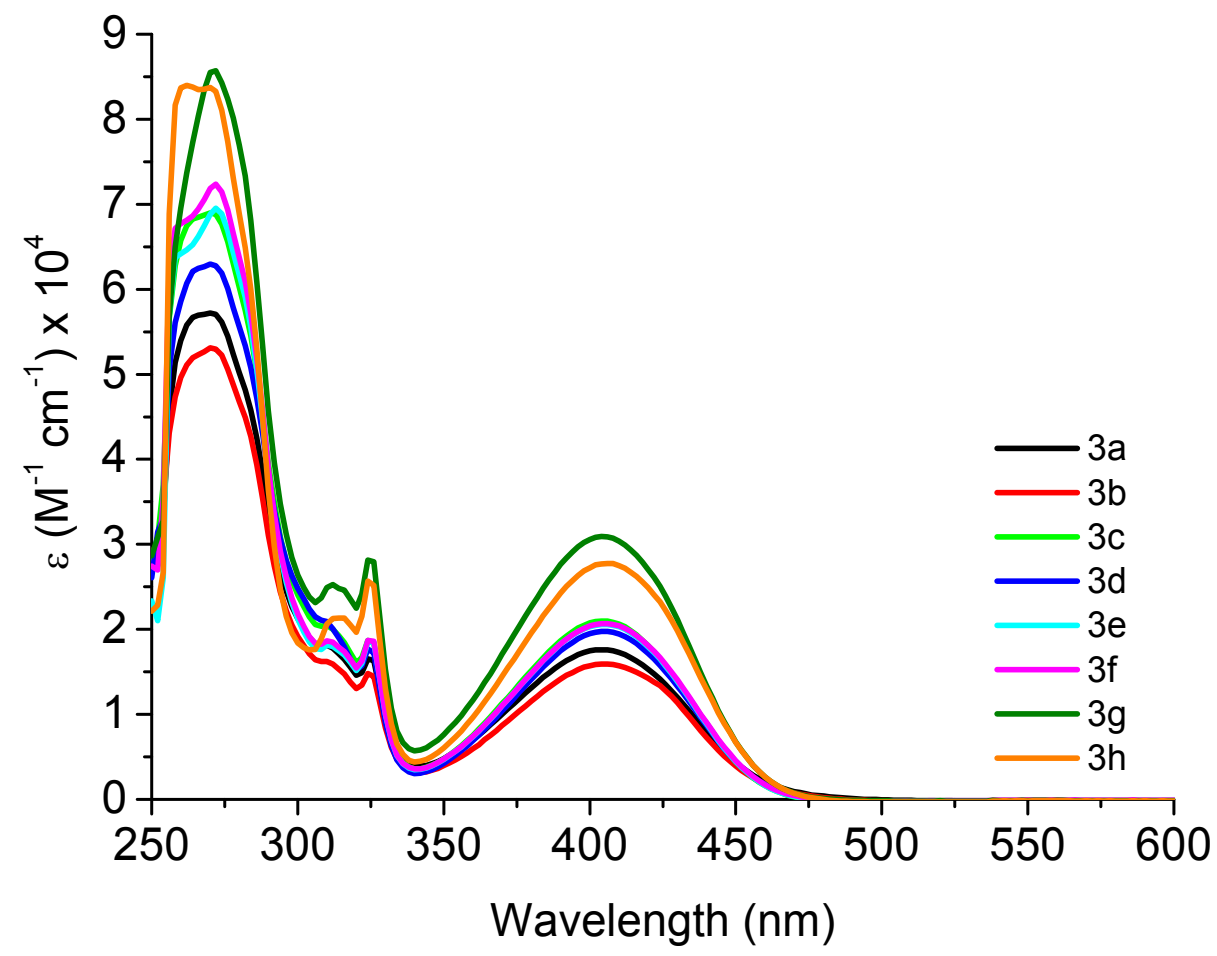

Figure S24. UV-Vis absorption spectra of derivatives in DMSO ([ ] = $10^{-5} \mathrm{M}$ range). 


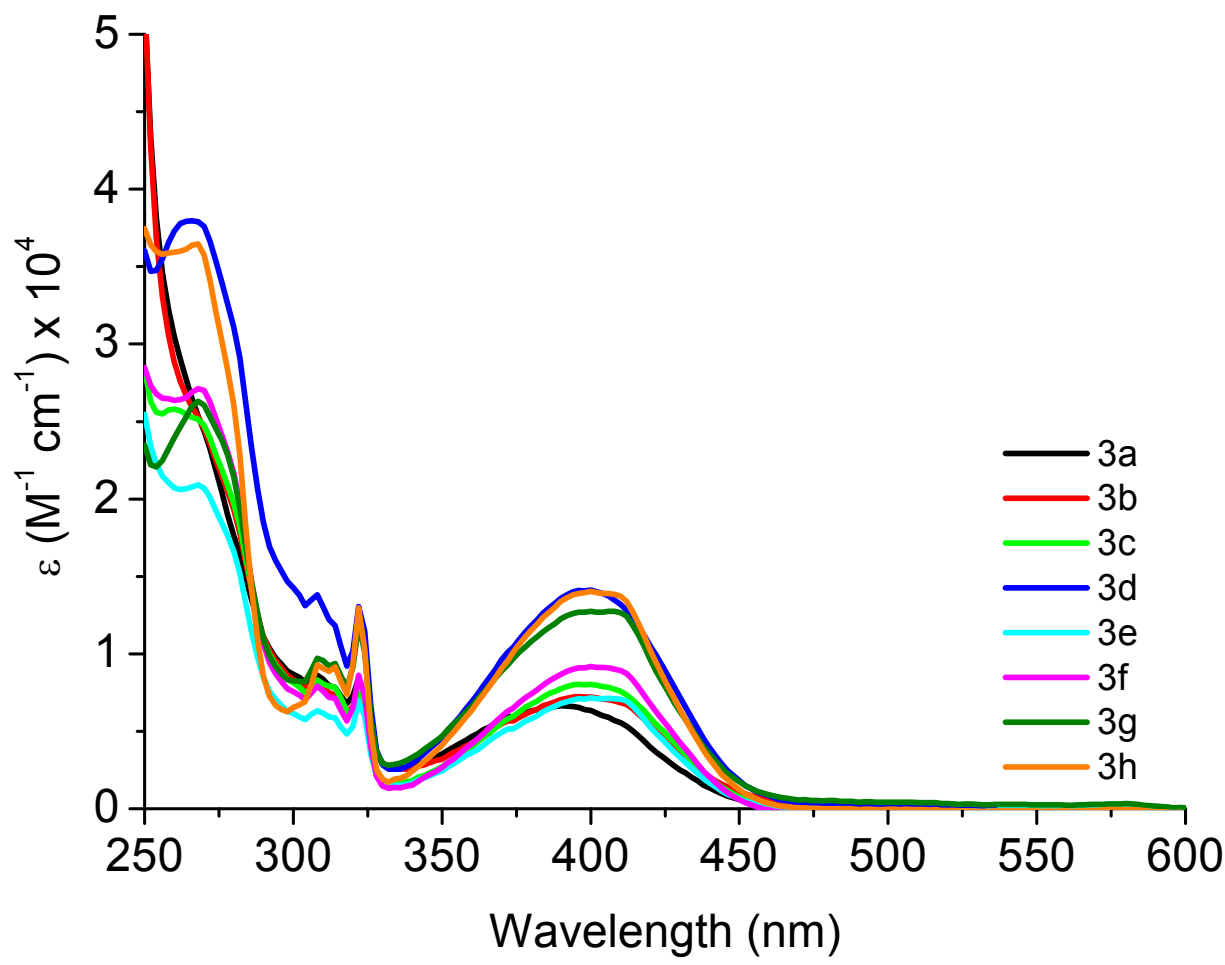

Figure S25. UV-Vis absorption spectra of derivatives in $\mathrm{MeOH}\left([]=10^{-5} \mathrm{M}\right.$ range).

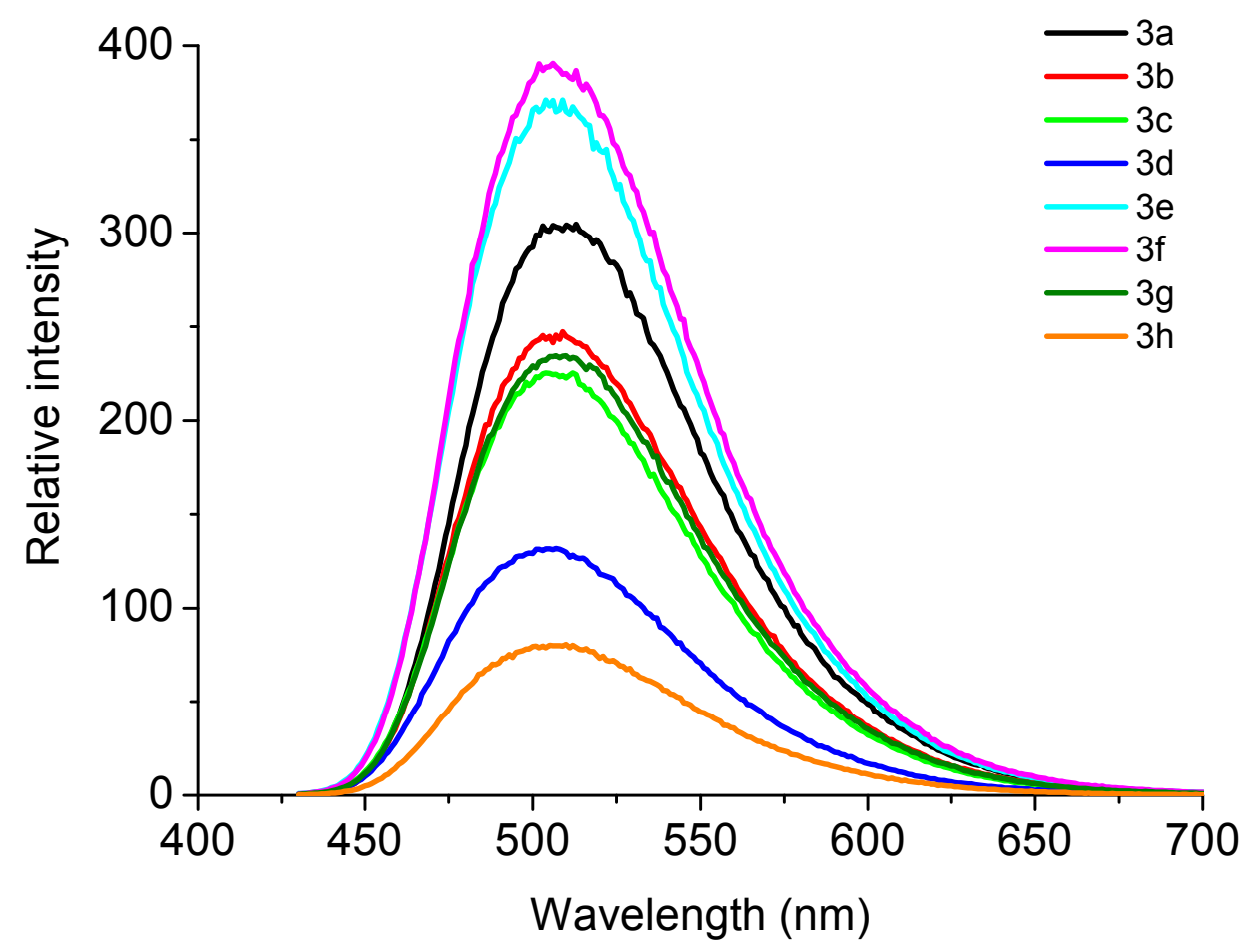

Figure S26. Steady-state emission spectra of derivatives in DCM ([ ] $=10^{-5} \mathrm{M}$ range). 


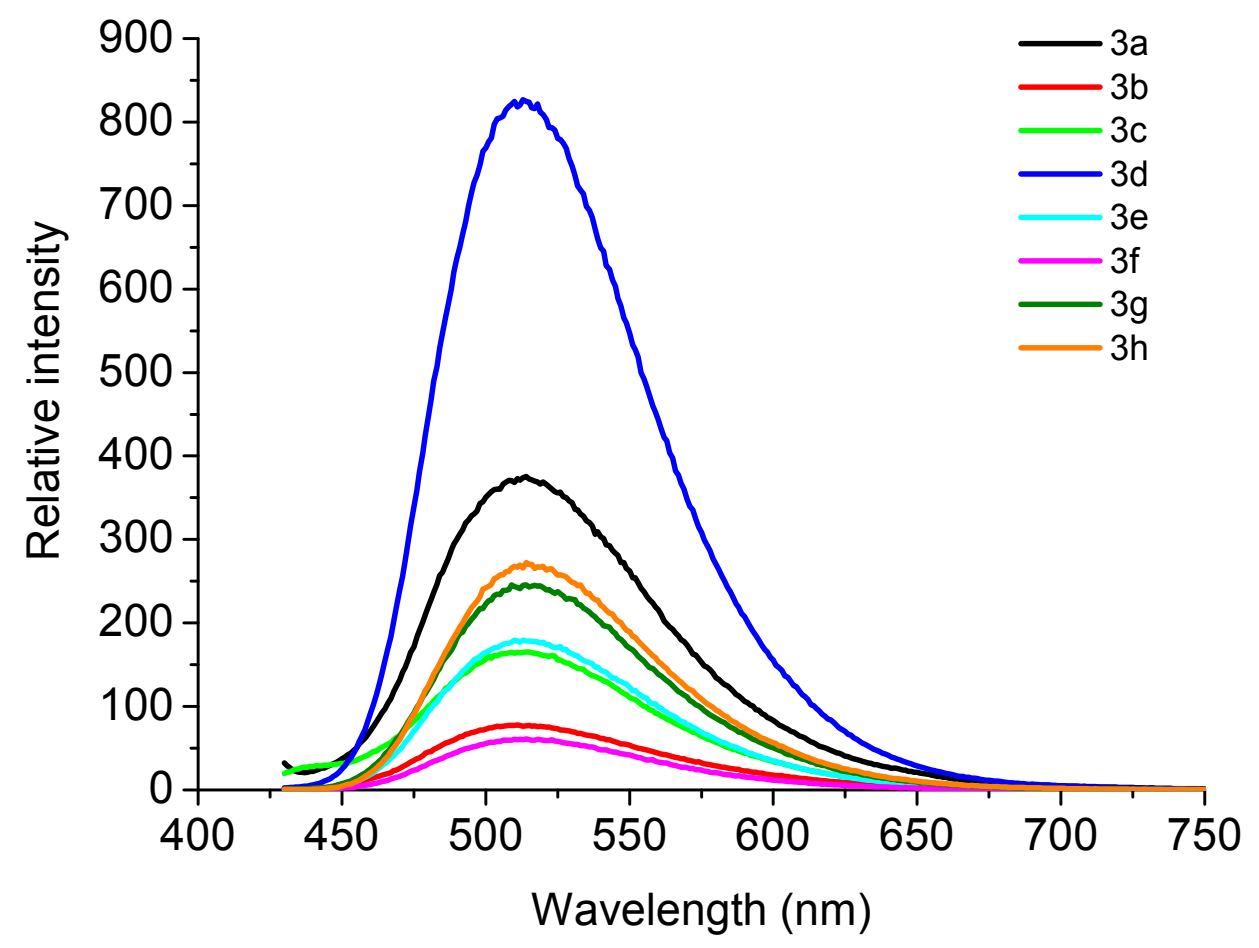

Figure S27. Steady-state emission spectra of derivatives in DMSO ([ ] $=10^{-5} \mathrm{M}$ range).

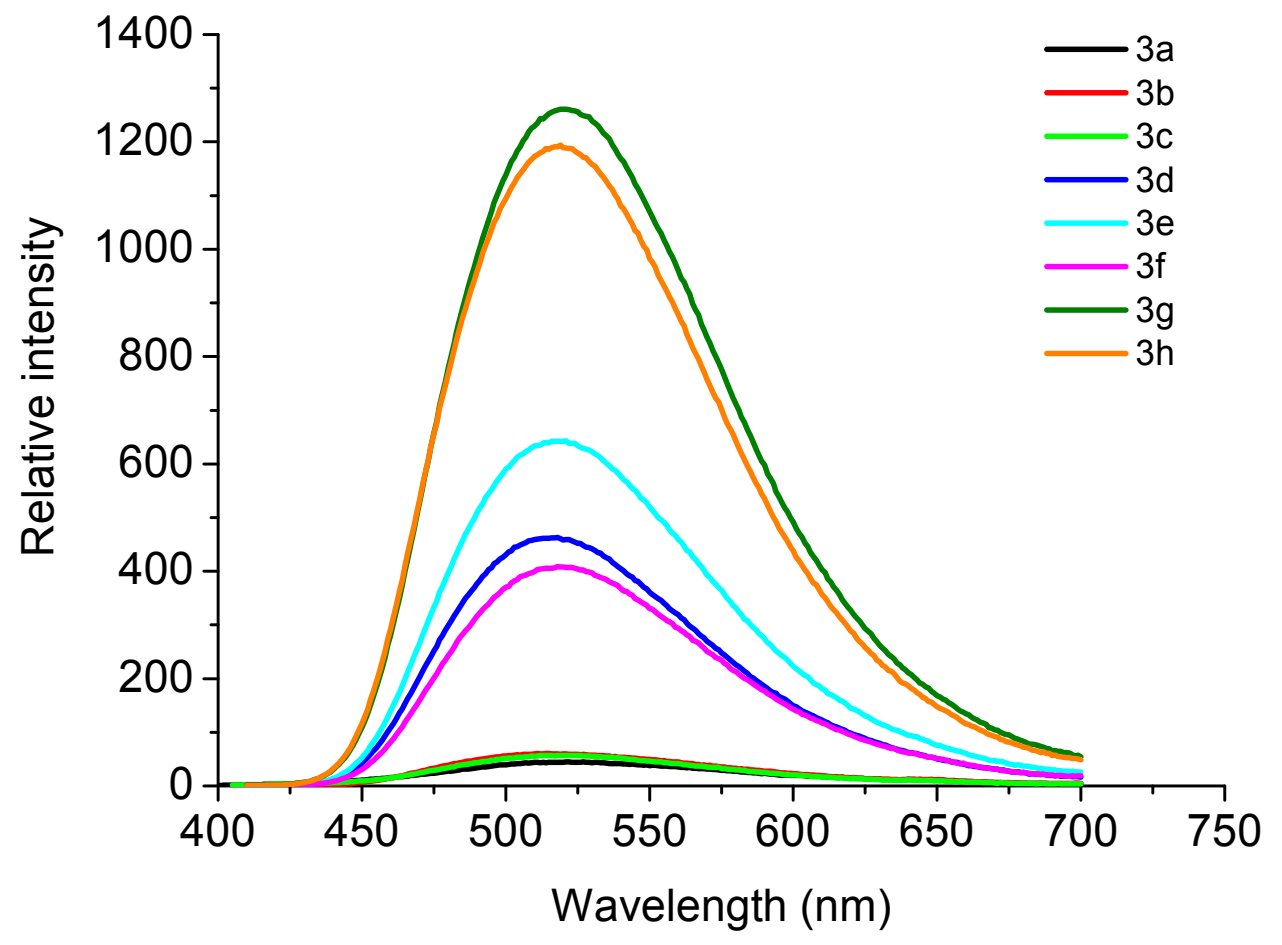

Figure S28. Steady-state emission spectra of derivatives in $\mathrm{MeOH}\left([]=10^{-5} \mathrm{M}\right.$ range). 


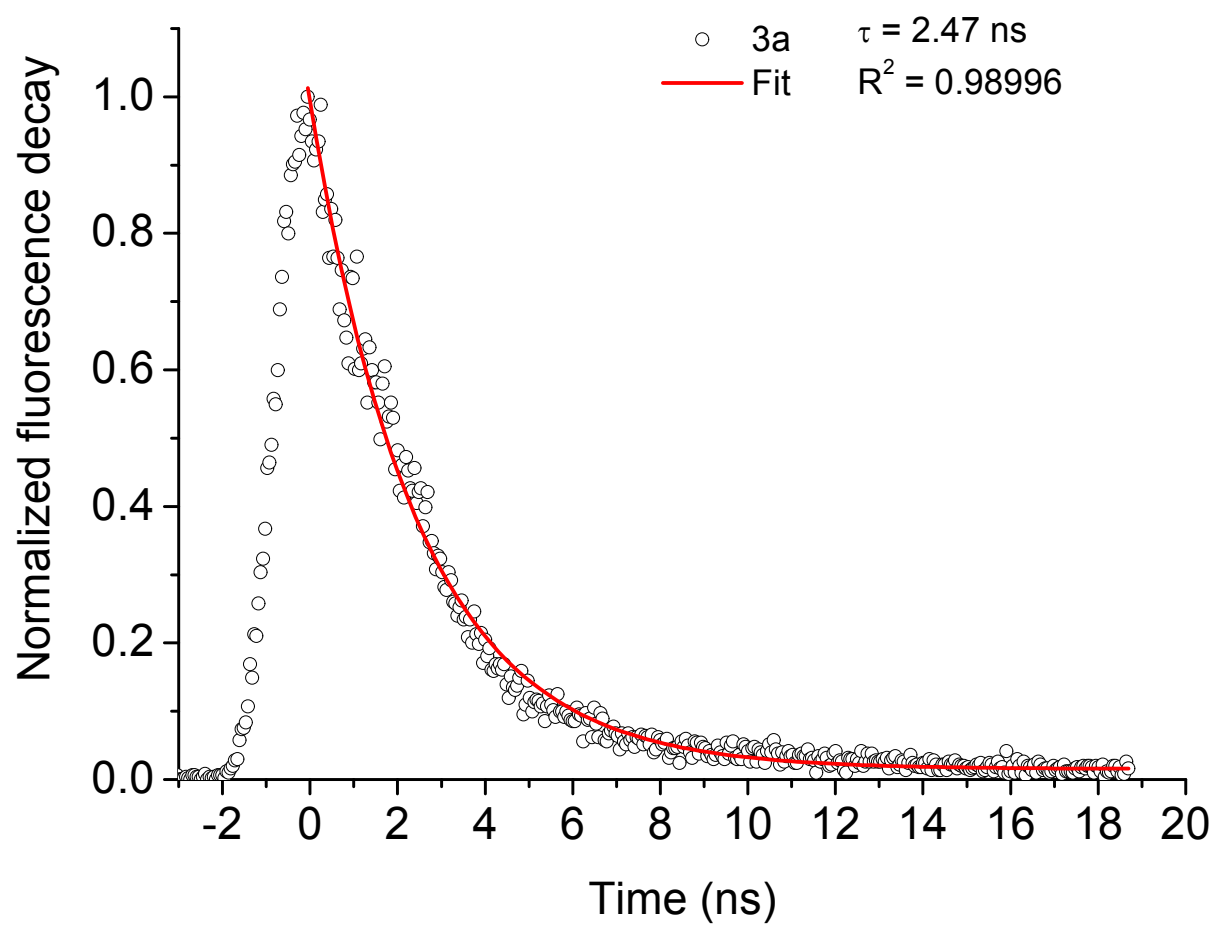

Figure S29. Fluorescence decay time of derivative $\mathbf{3 a}$ in DCM solutions.

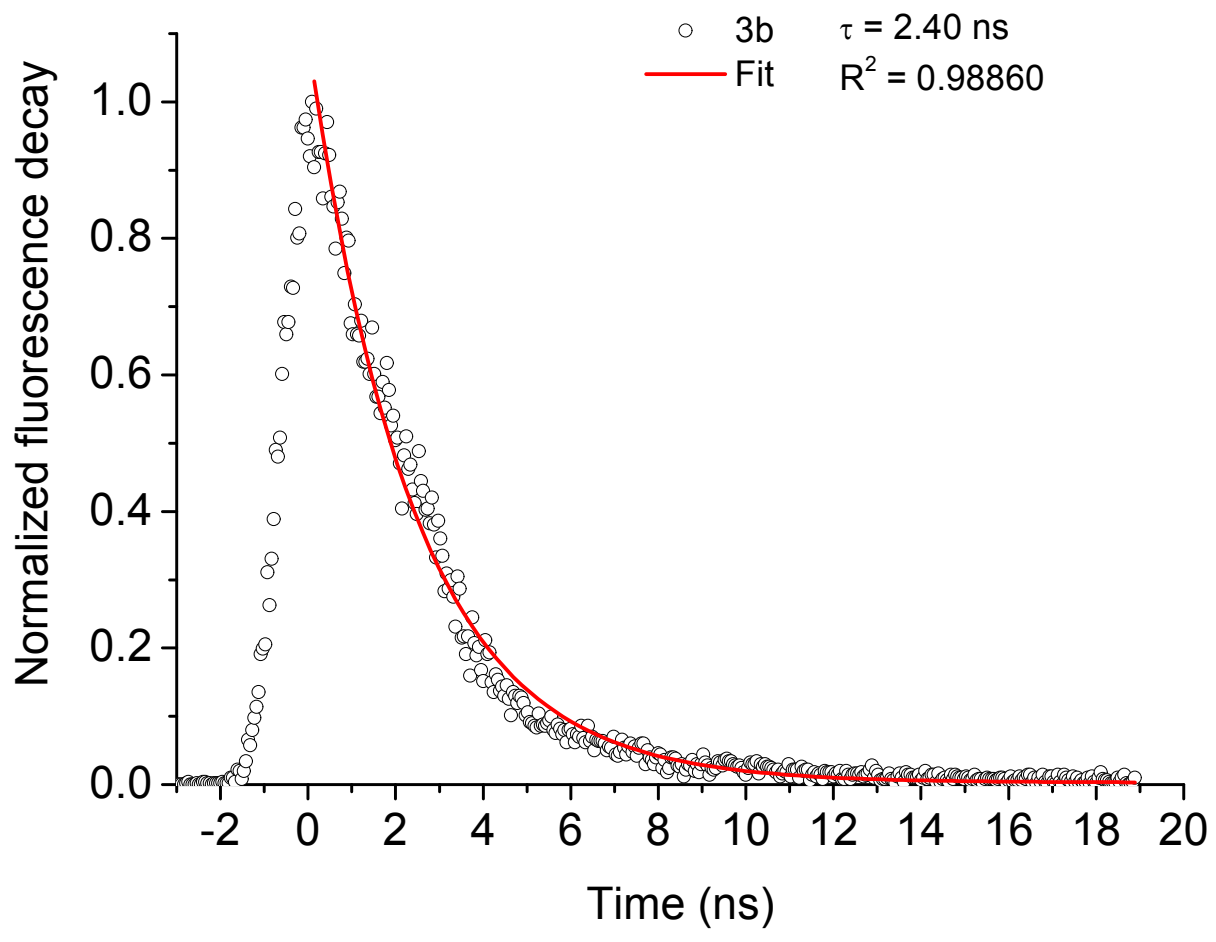

Figure S30. Fluorescence decay time of derivative $\mathbf{3 b}$ in DCM solutions. 


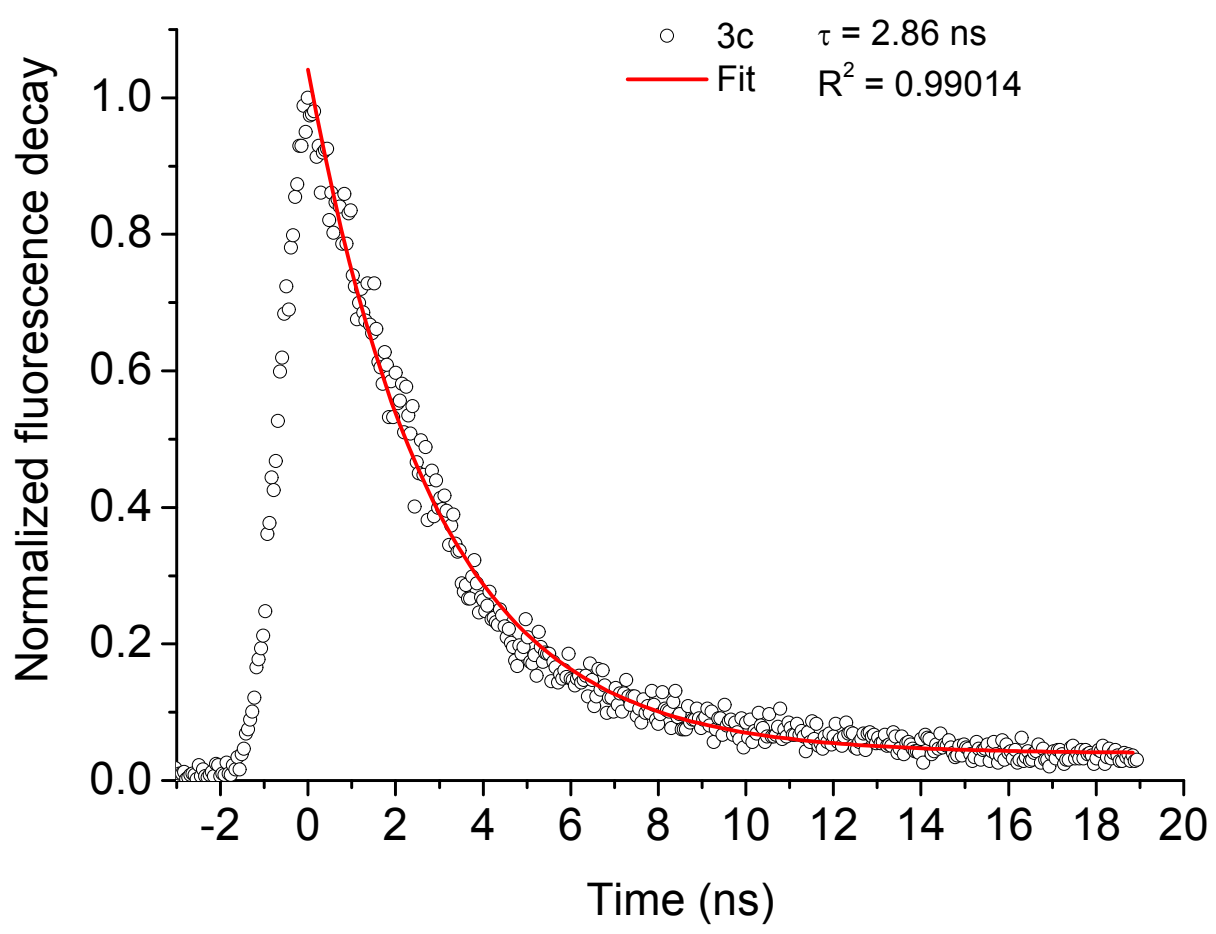

Figure S31. Fluorescence decay time of derivative $3 c$ in DCM solutions.

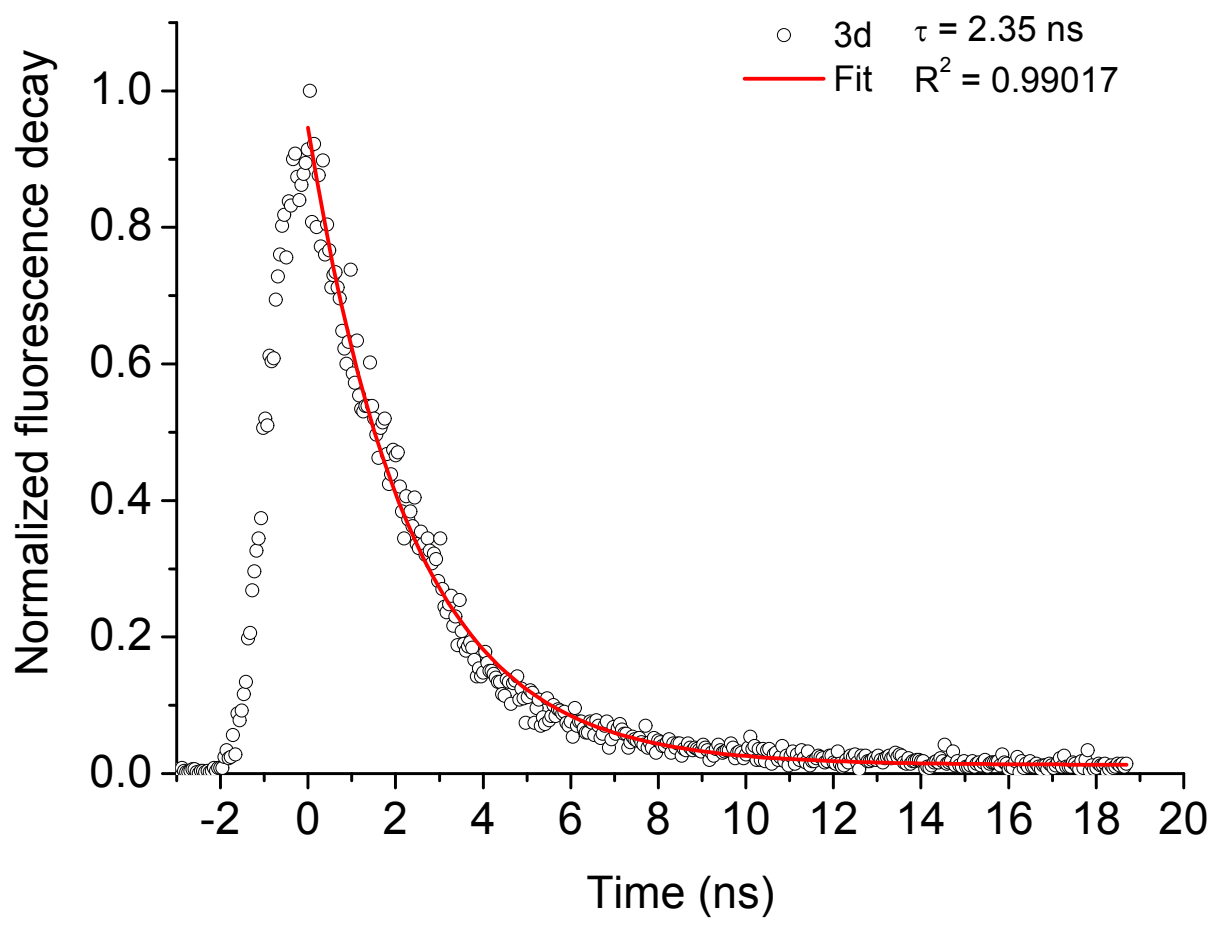

Figure S32. Fluorescence decay time of derivative $3 \mathbf{d}$ in DCM solutions. 


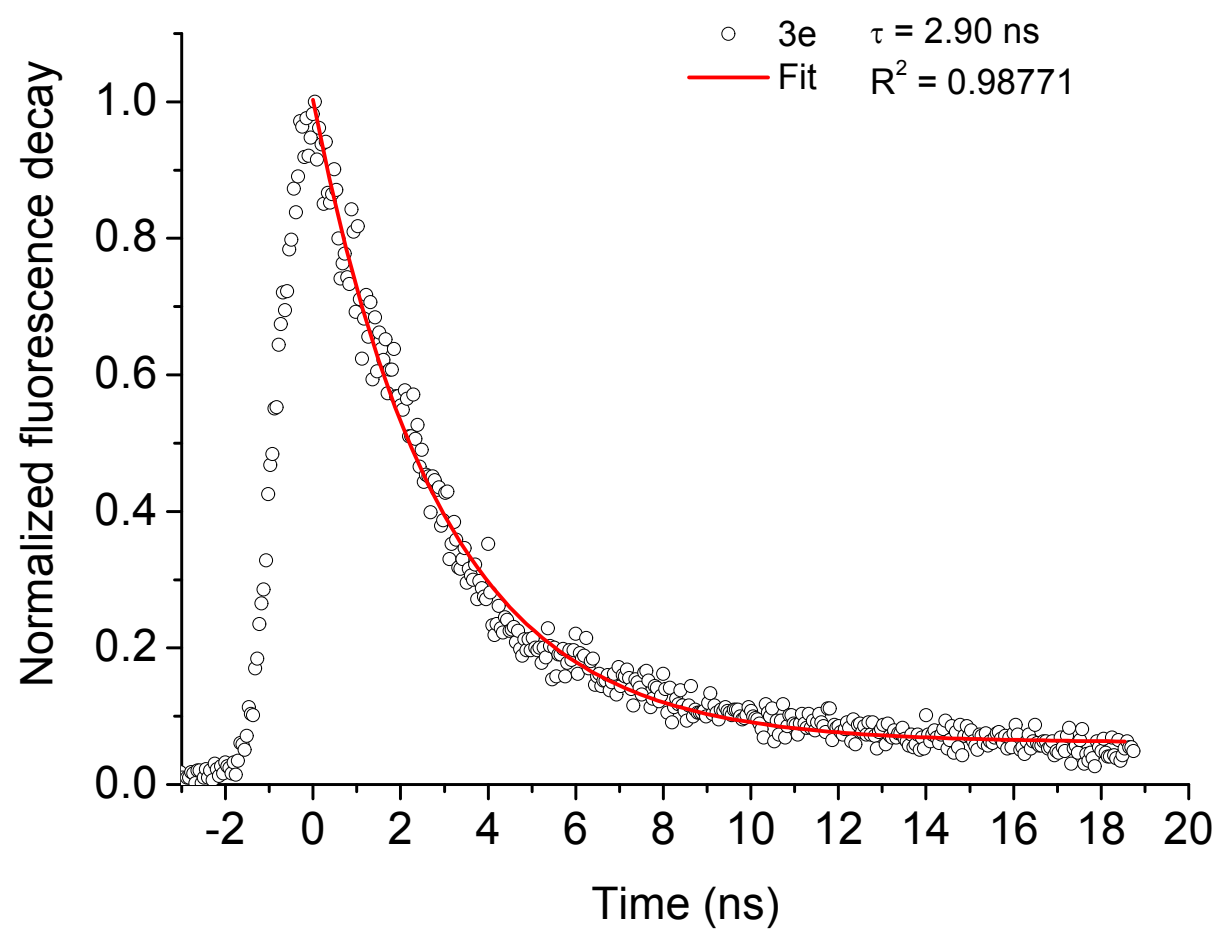

Figure S33. Fluorescence decay time of derivative $3 e$ in DCM solutions.

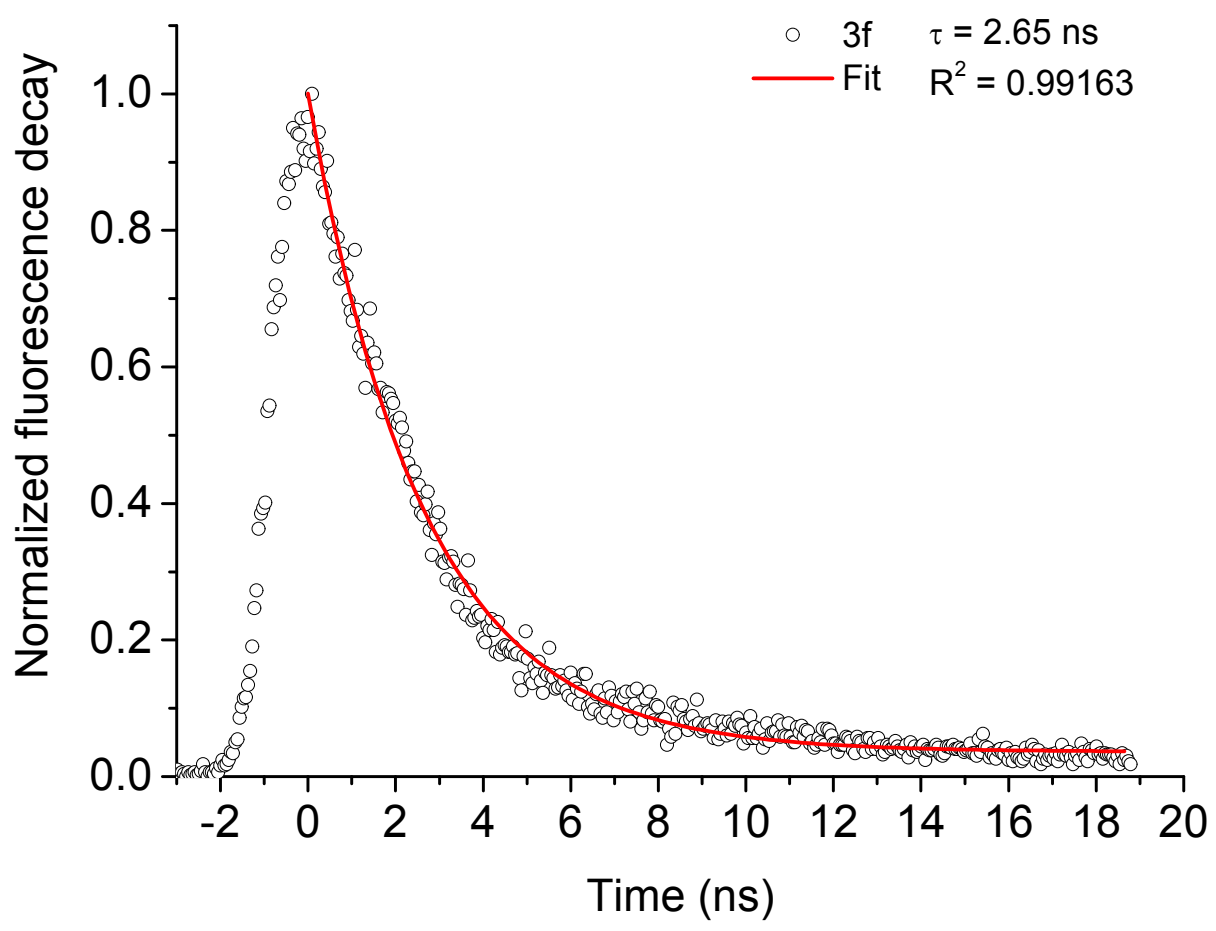

Figure S34. Fluorescence decay time of derivative $3 \mathbf{f}$ in DCM solutions. 


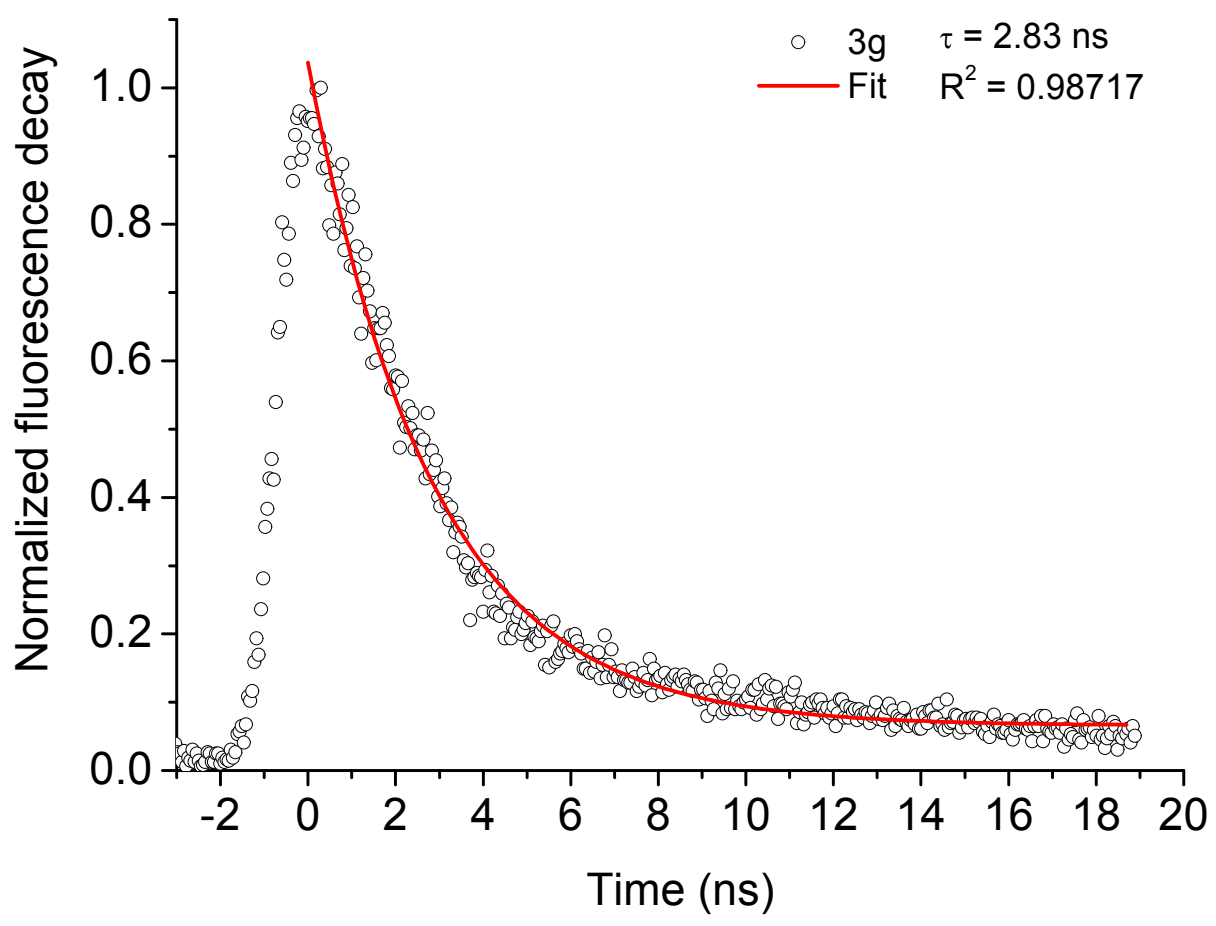

Figure S35. Fluorescence decay time of derivative $\mathbf{3 g}$ in DCM solutions.

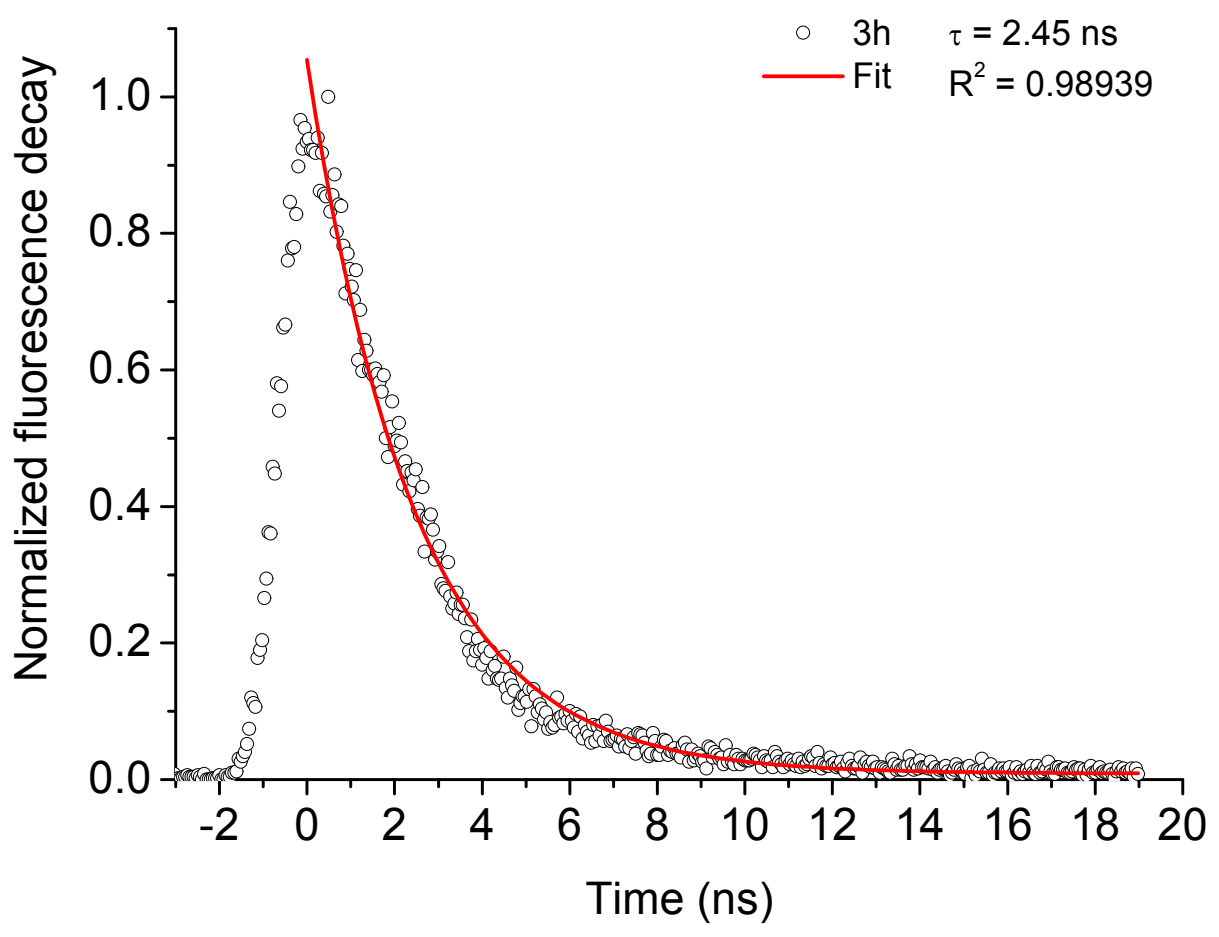

Figure S36. Fluorescence decay time of derivative $3 \mathrm{~h}$ in DCM solutions. 


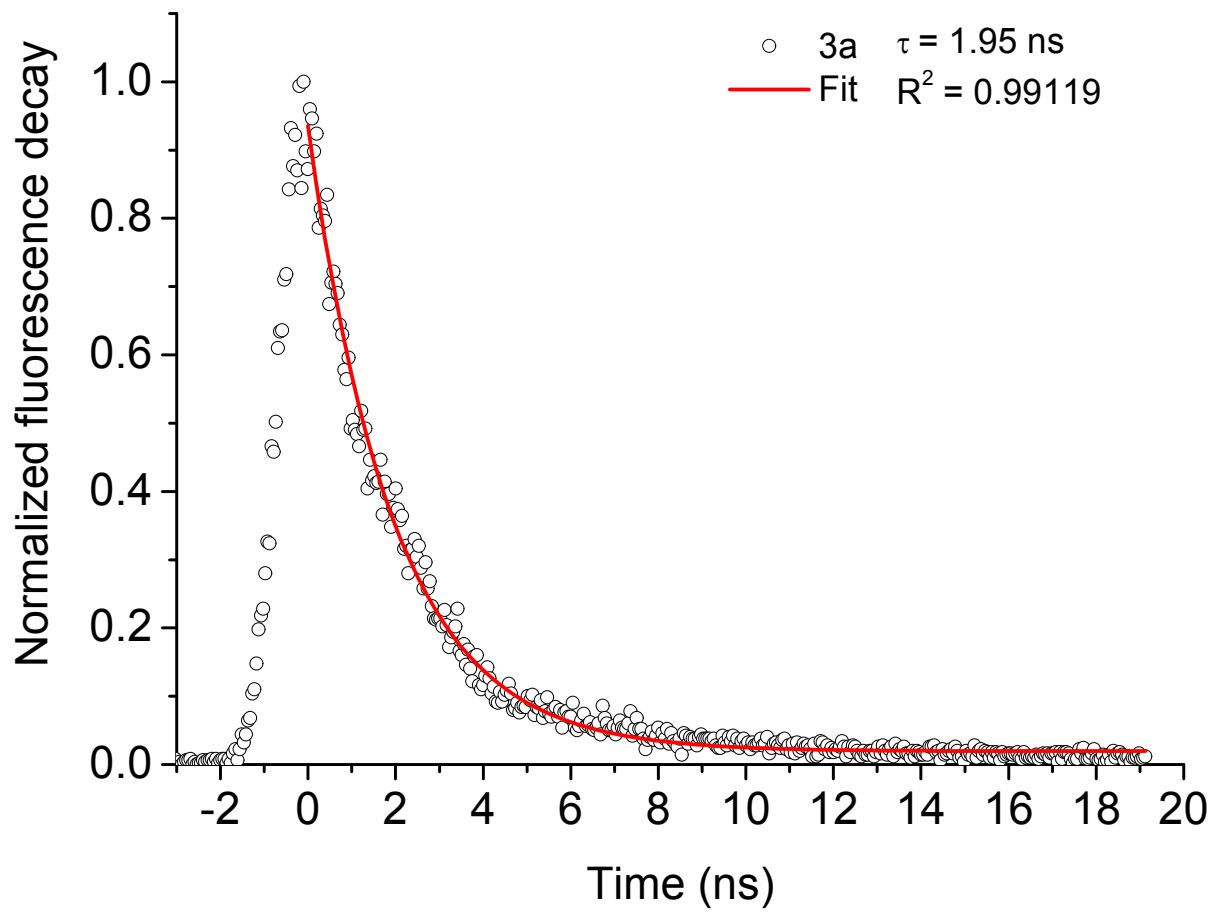

Figure S37. Fluorescence decay time of derivative $\mathbf{3 a}$ in DMSO solutions.

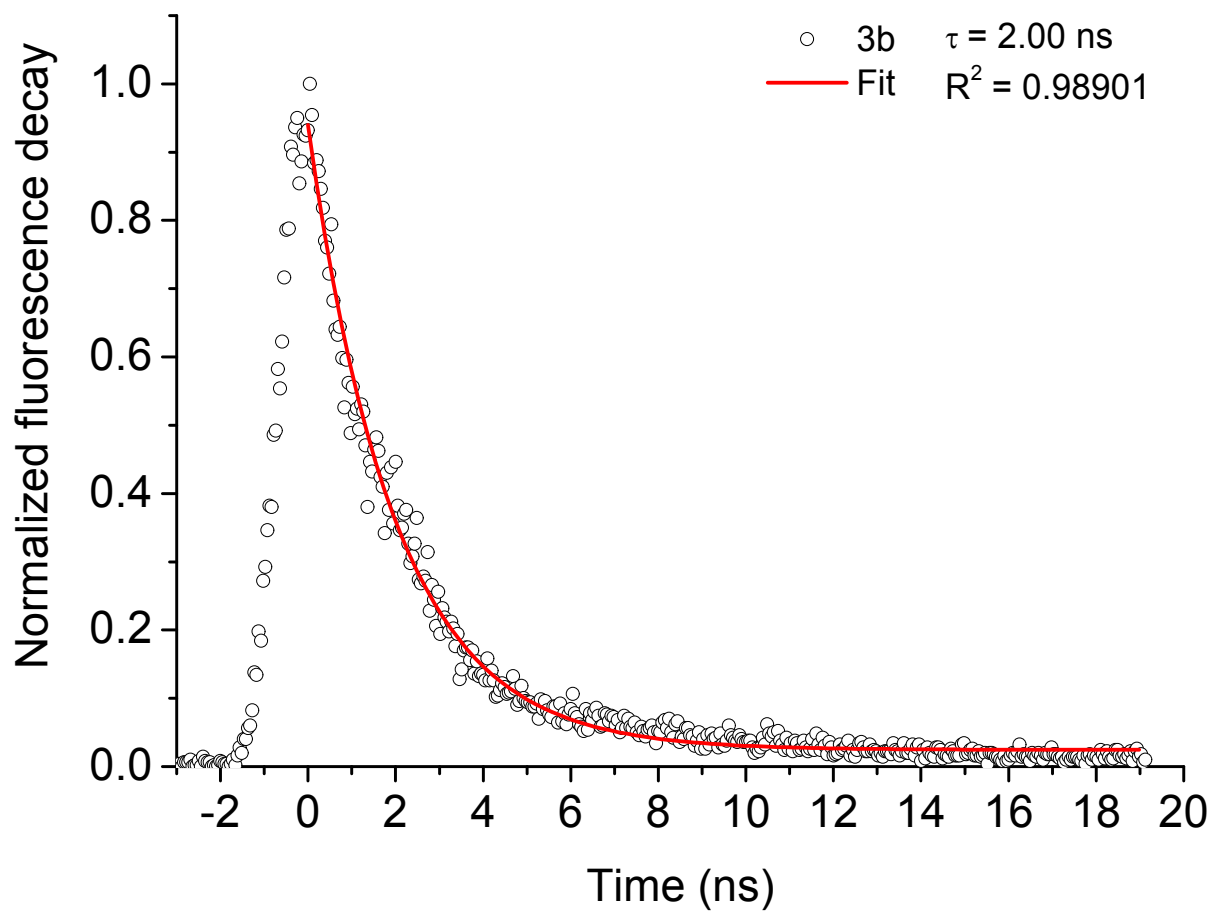

Figure S38. Fluorescence decay time of derivative $\mathbf{3 b}$ in DMSO solutions. 


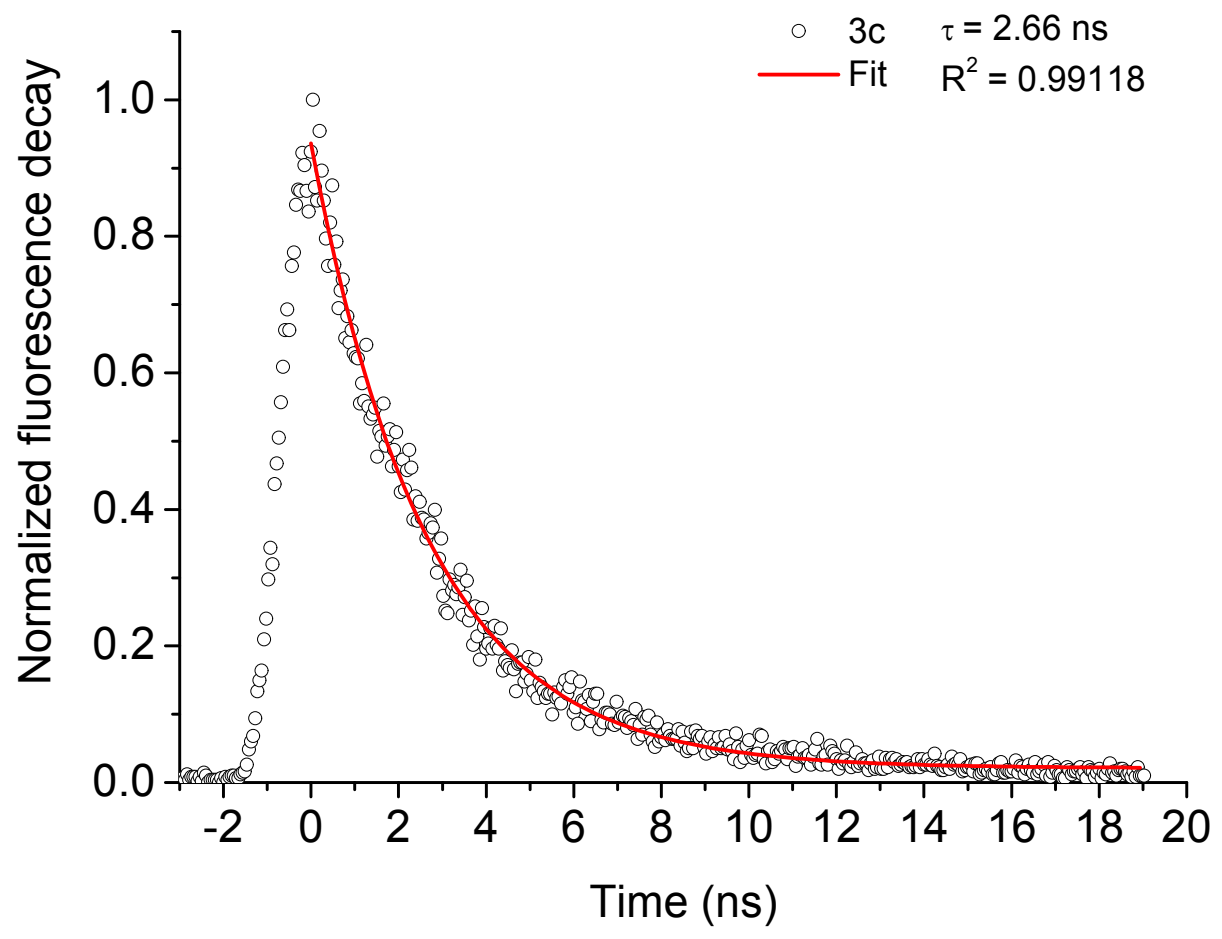

Figure S39. Fluorescence decay time of derivative $3 c$ in DMSO solutions.

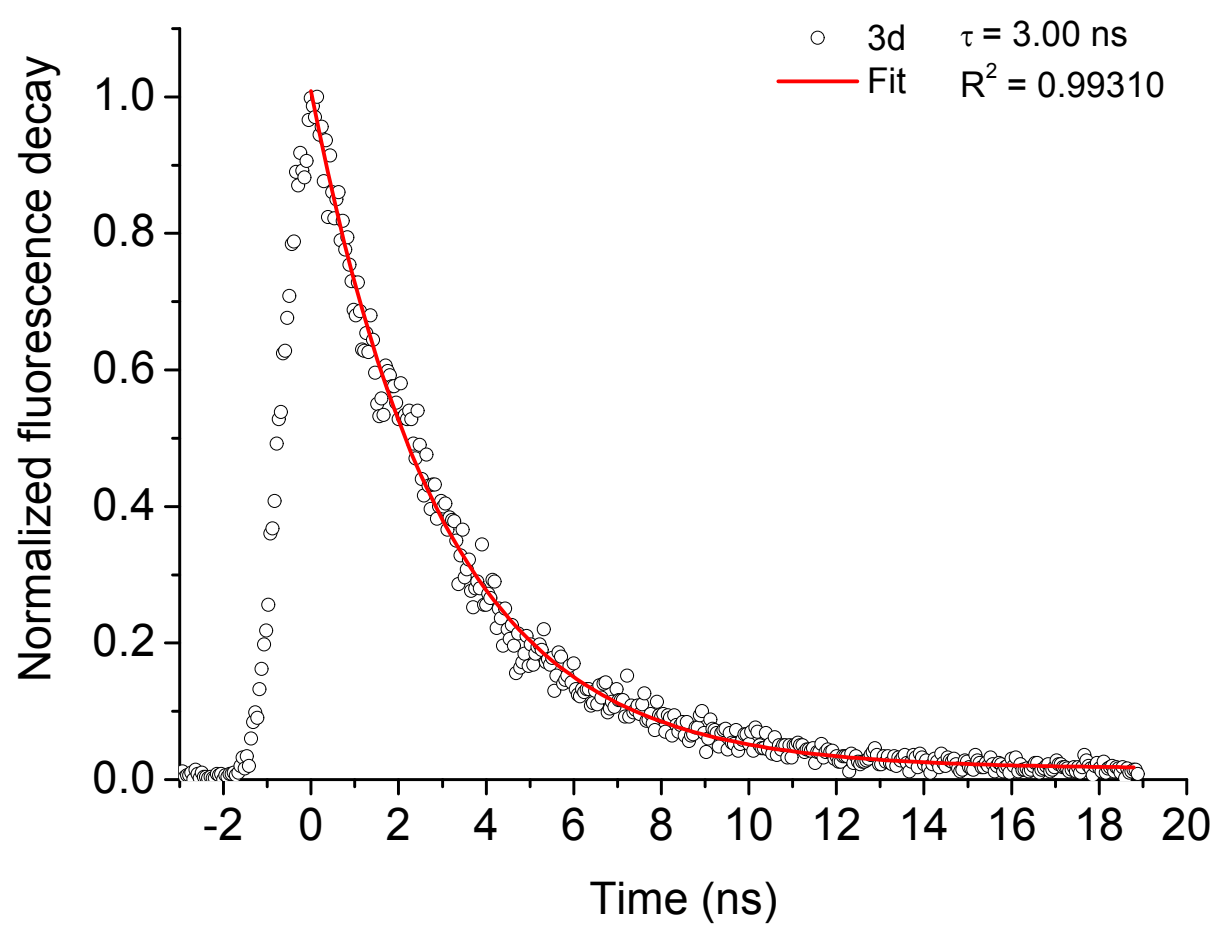

Figure S40. Fluorescence decay time of derivative $\mathbf{3 d}$ in DMSO solutions. 


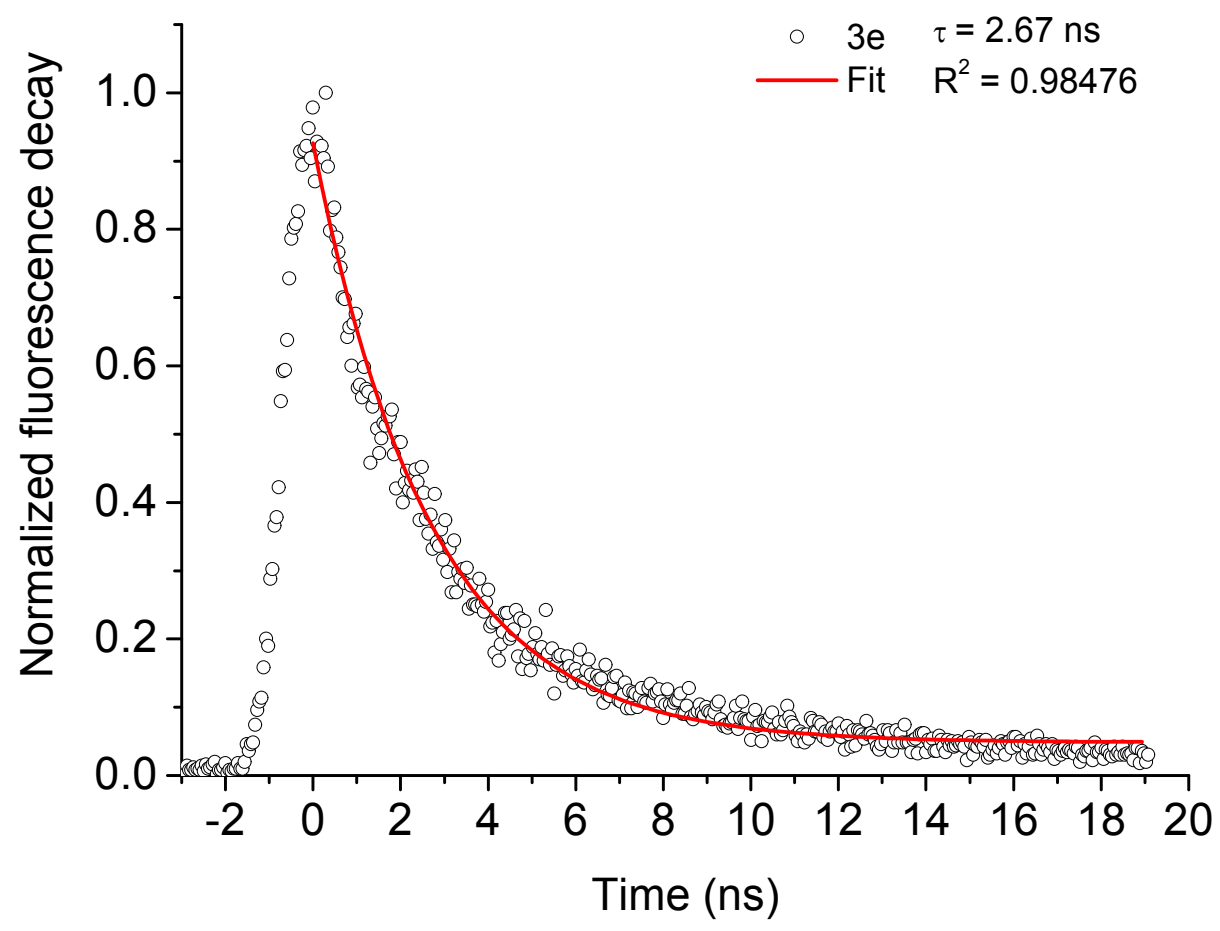

Figure S41. Fluorescence decay time of derivative $3 e$ in DMSO solutions.

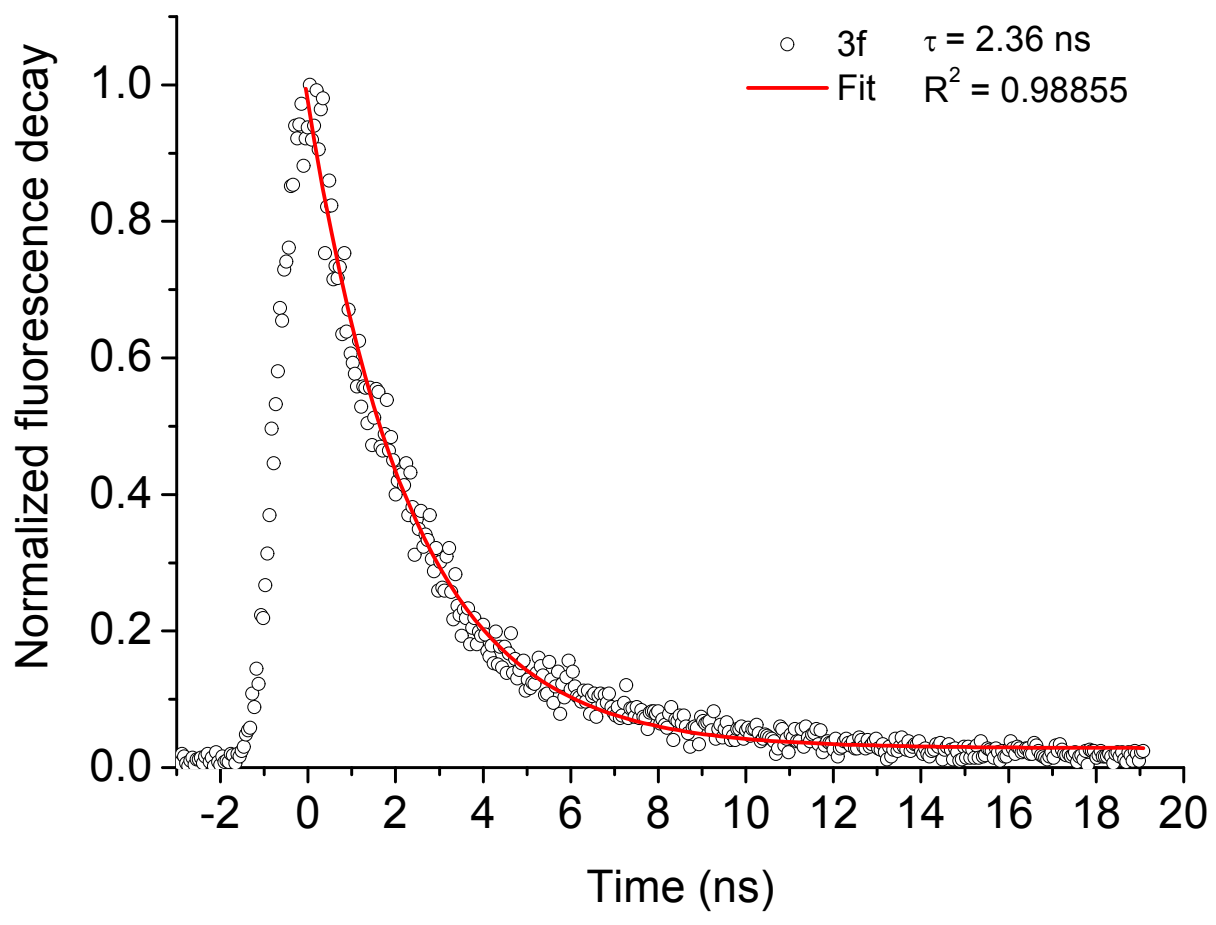

Figure S42. Fluorescence decay time of derivative $\mathbf{3 f}$ in DMSO solutions. 


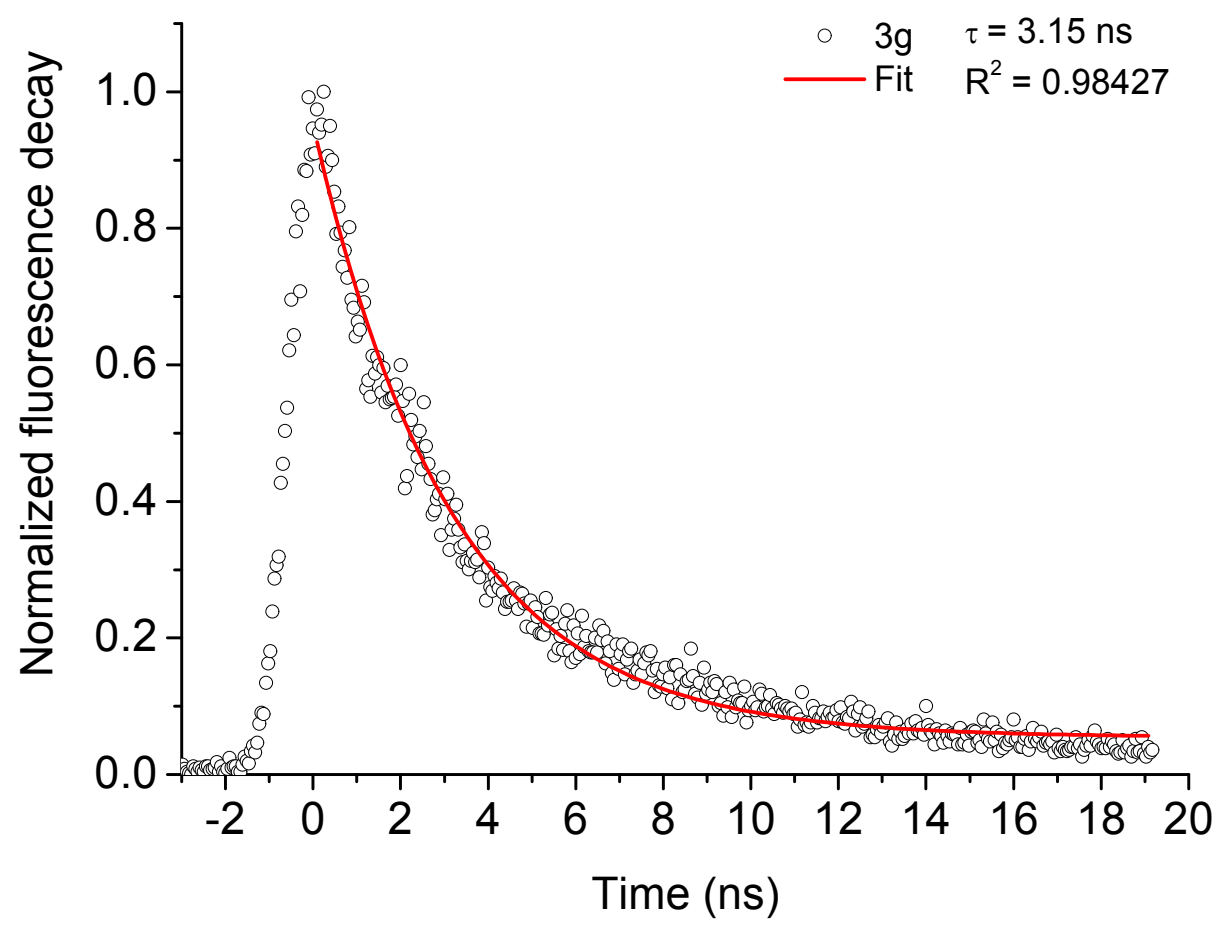

Figure S43. Fluorescence decay time of derivative $\mathbf{3 g}$ in DMSO solutions.

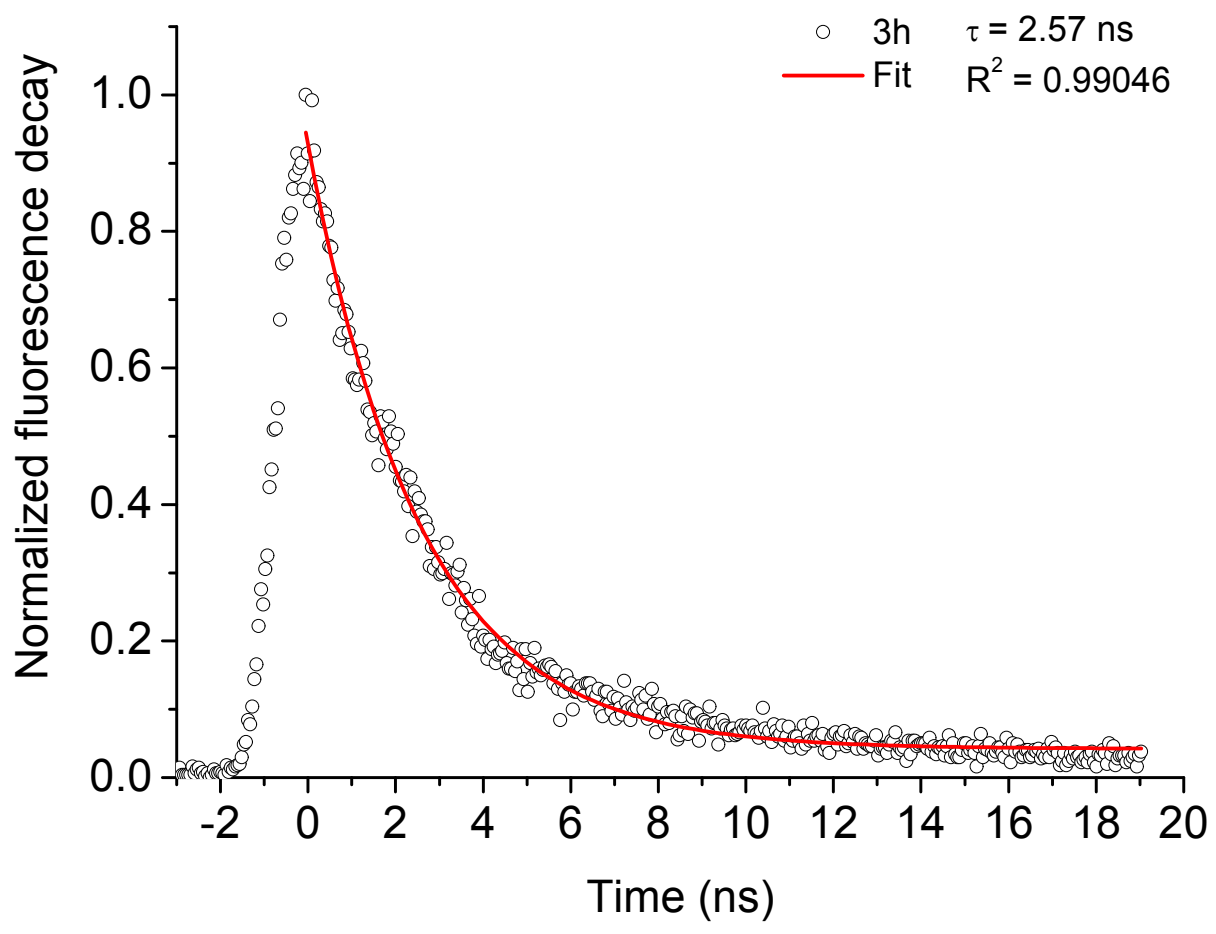

Figure S44. Fluorescence decay time of derivative $3 \mathrm{~h}$ in DMSO solutions. 


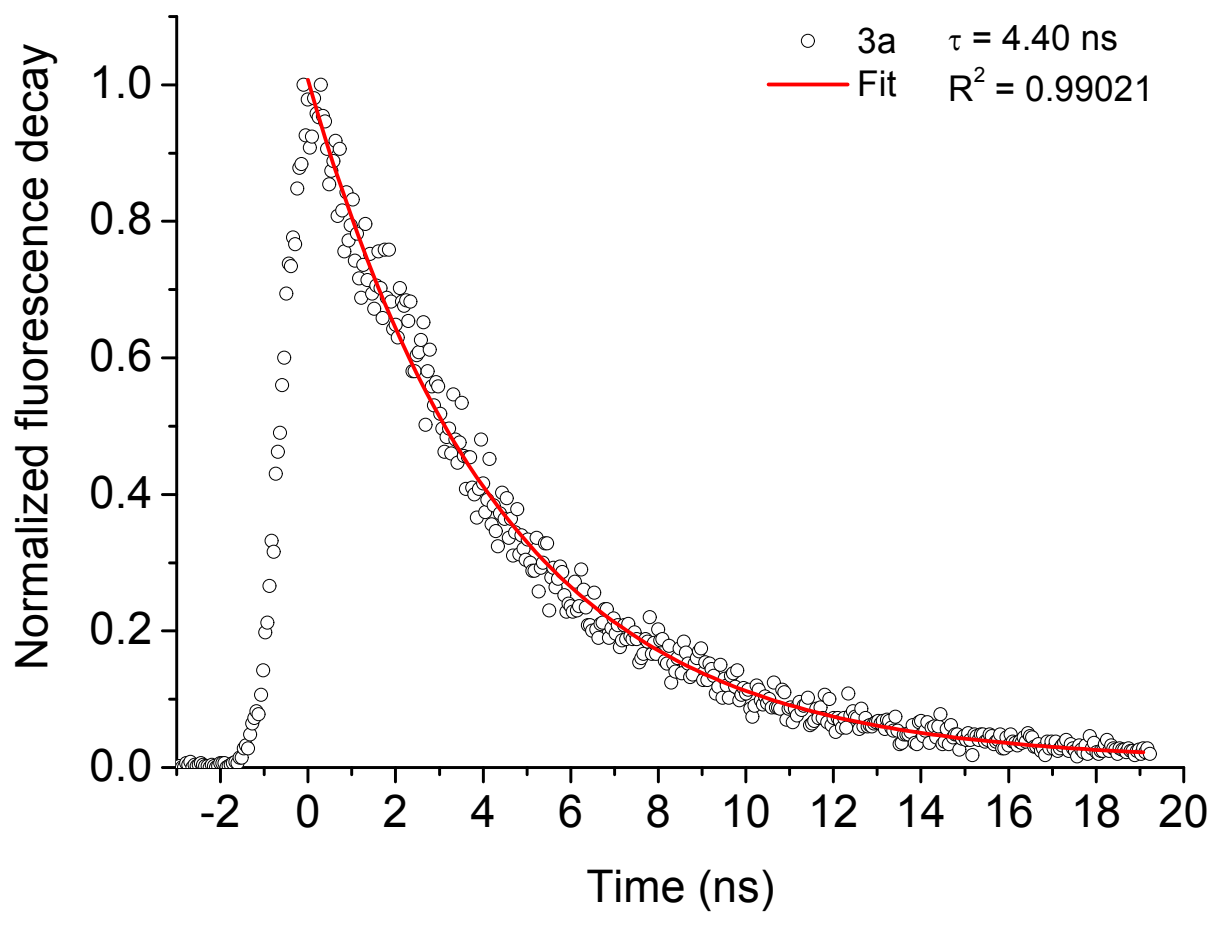

Figure S45. Fluorescence decay time of derivative $\mathbf{3 a}$ in $\mathrm{MeOH}$ solutions.

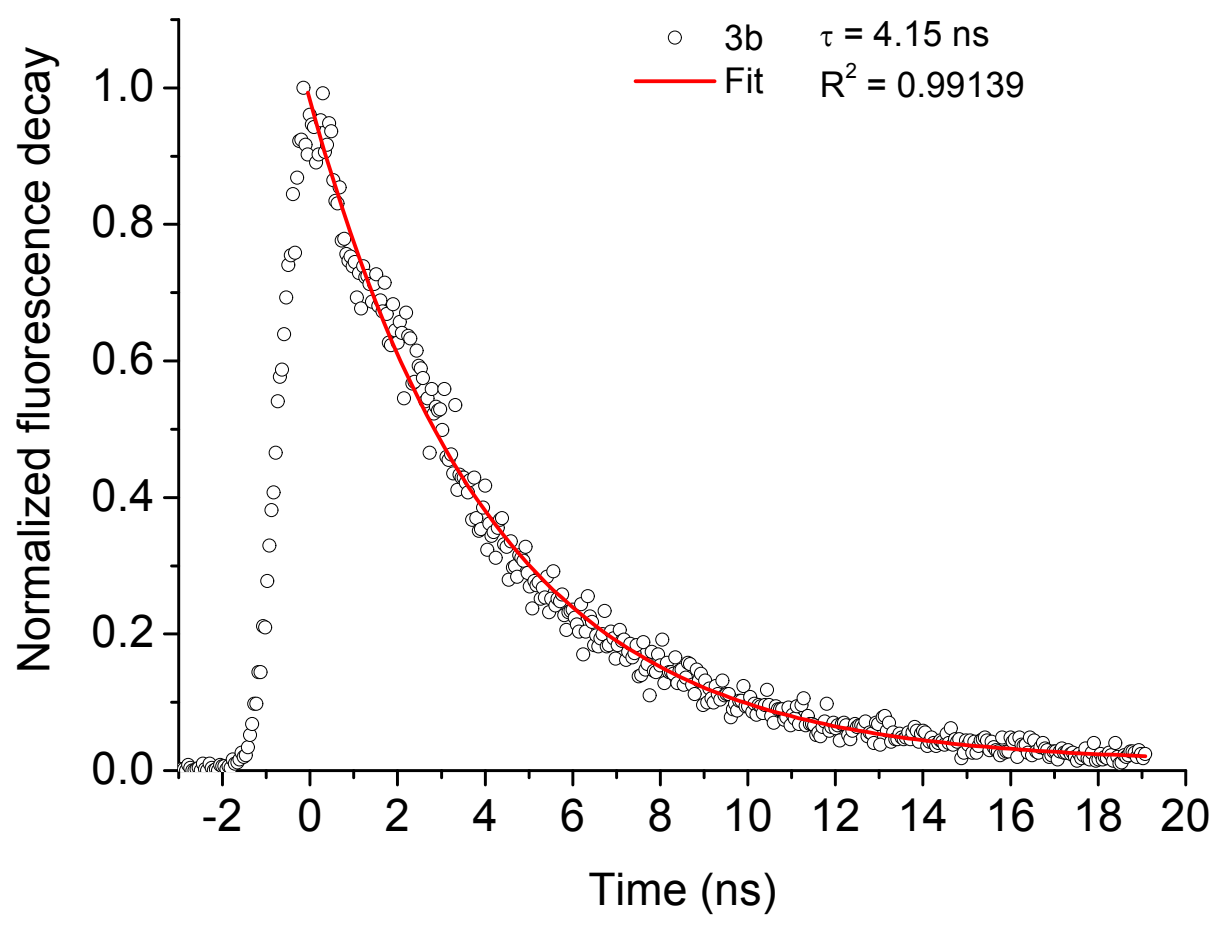

Figure S46. Fluorescence decay time of derivative $\mathbf{3 b}$ in $\mathrm{MeOH}$ solutions. 


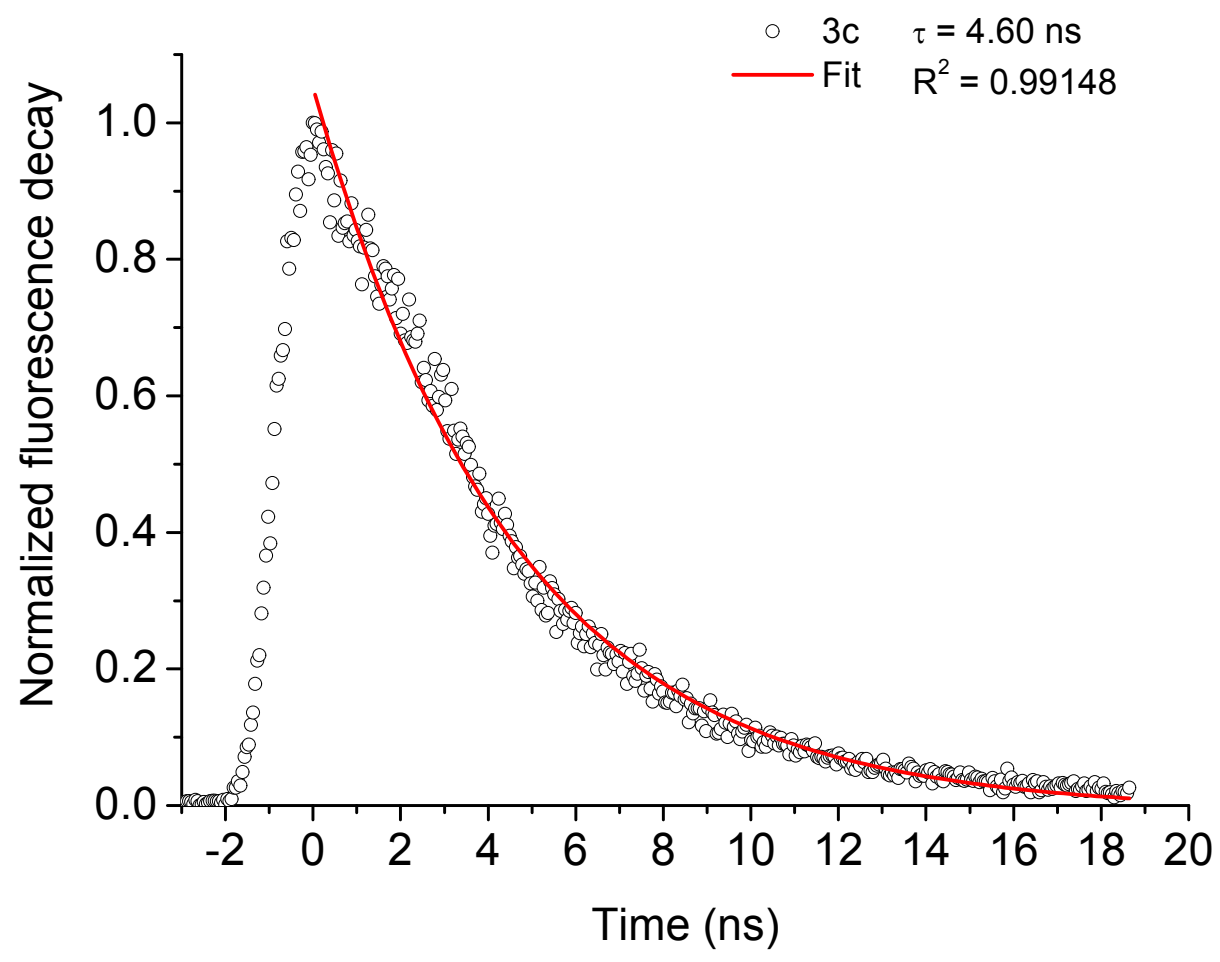

Figure S47. Fluorescence decay time of derivative $\mathbf{3 c}$ in $\mathrm{MeOH}$ solutions.

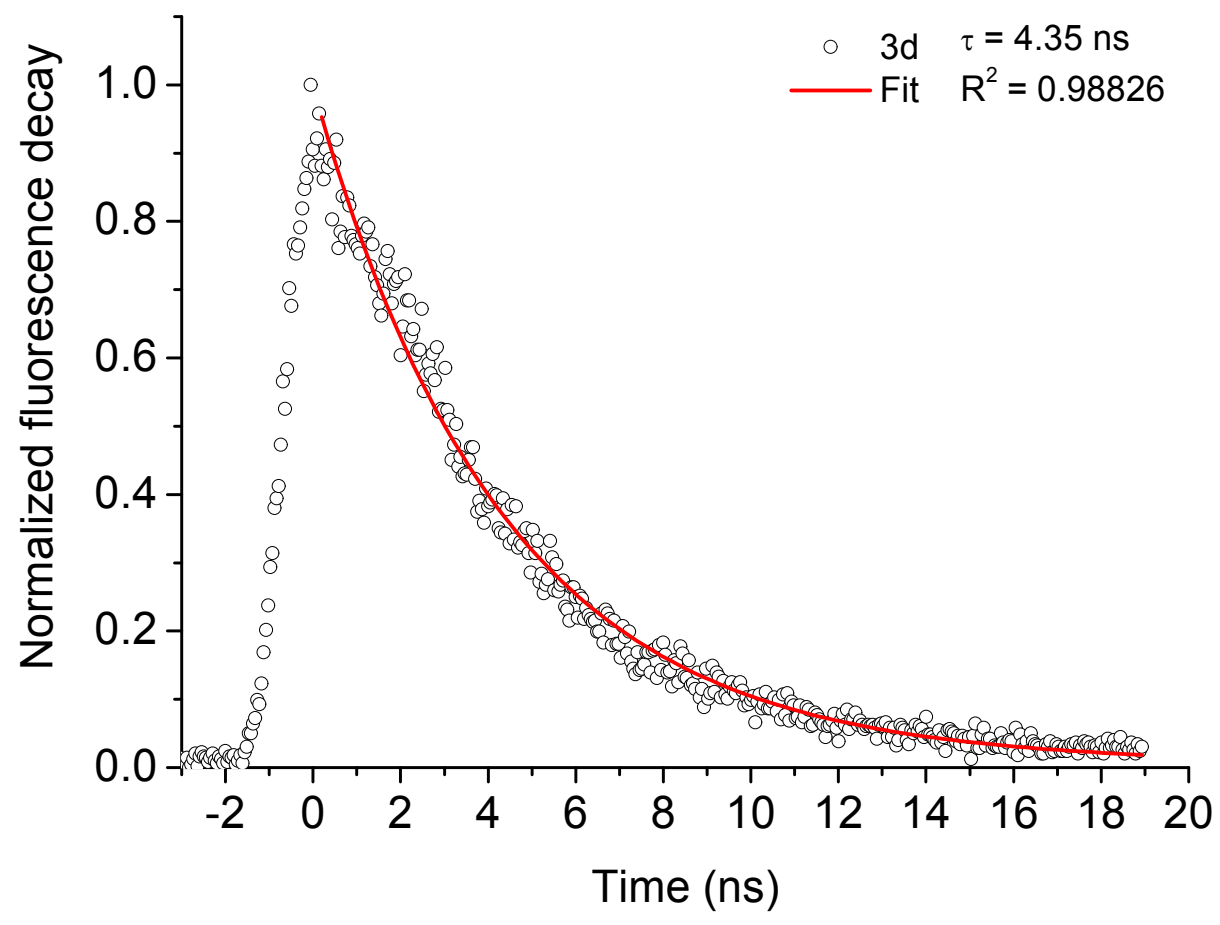

Figure S48. Fluorescence decay time of derivative $\mathbf{3} \mathbf{d}$ in $\mathrm{MeOH}$ solutions. 


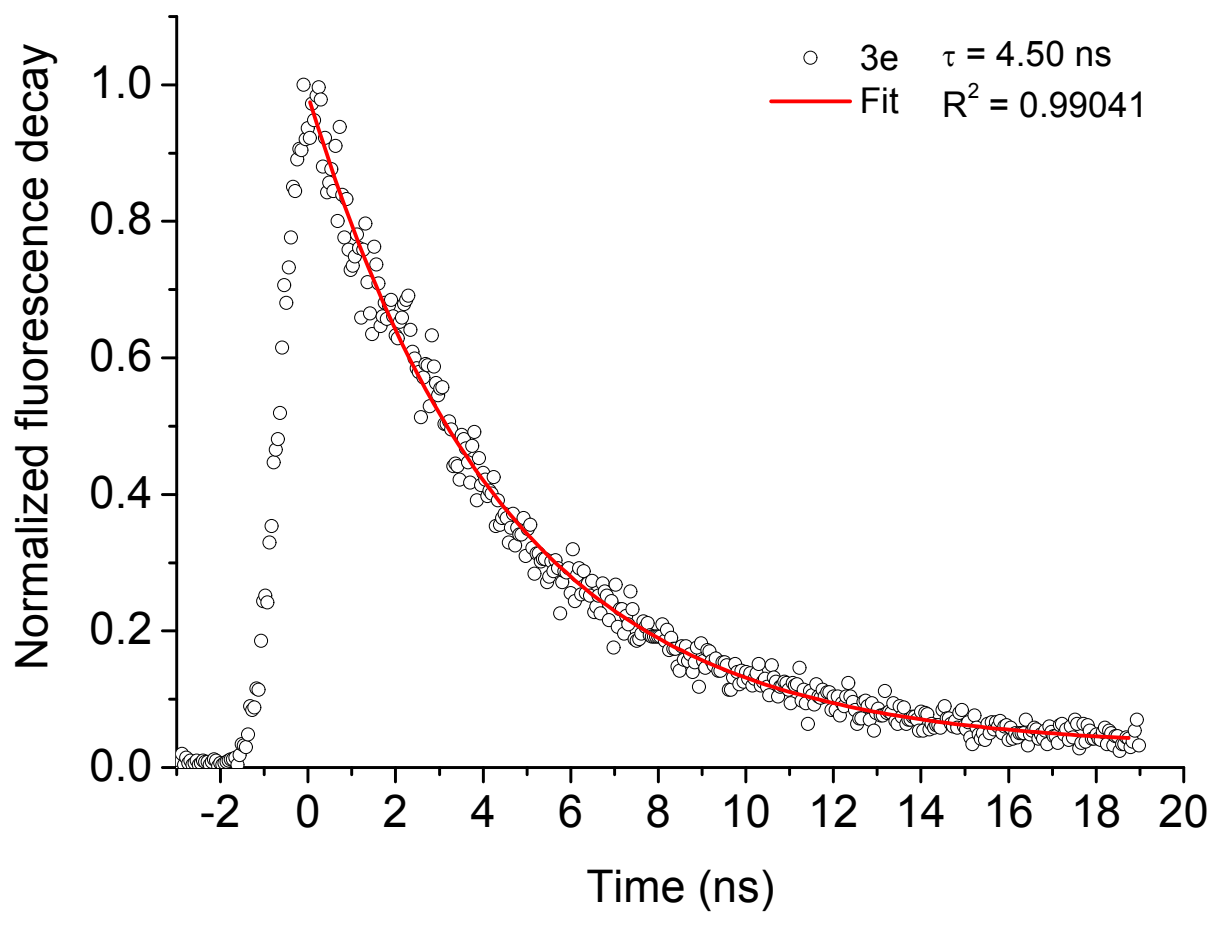

Figure S49. Fluorescence decay time of derivative $\mathbf{3 e}$ in $\mathrm{MeOH}$ solutions.

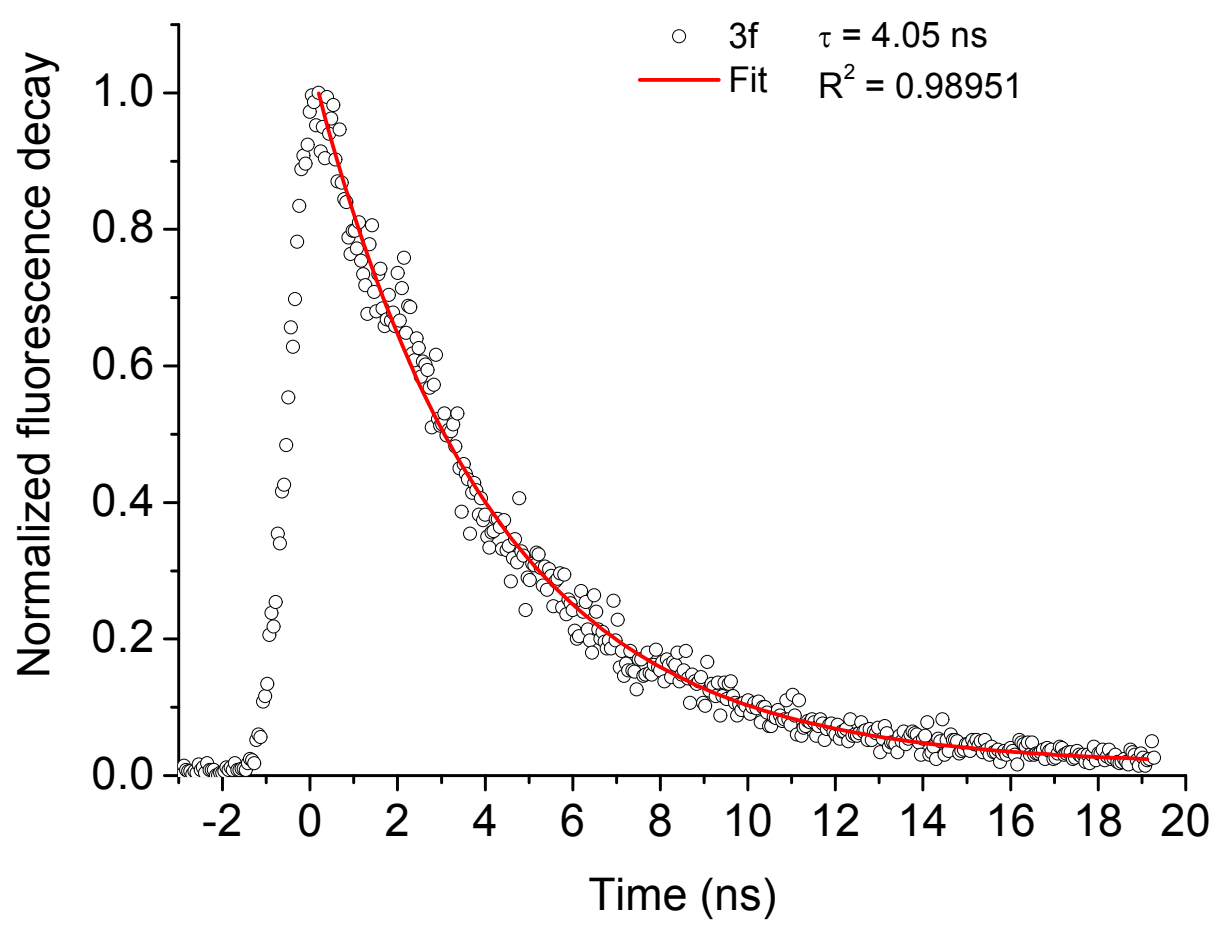

Figure S50. Fluorescence decay time of derivative $\mathbf{3 f}$ in $\mathrm{MeOH}$ solutions. 


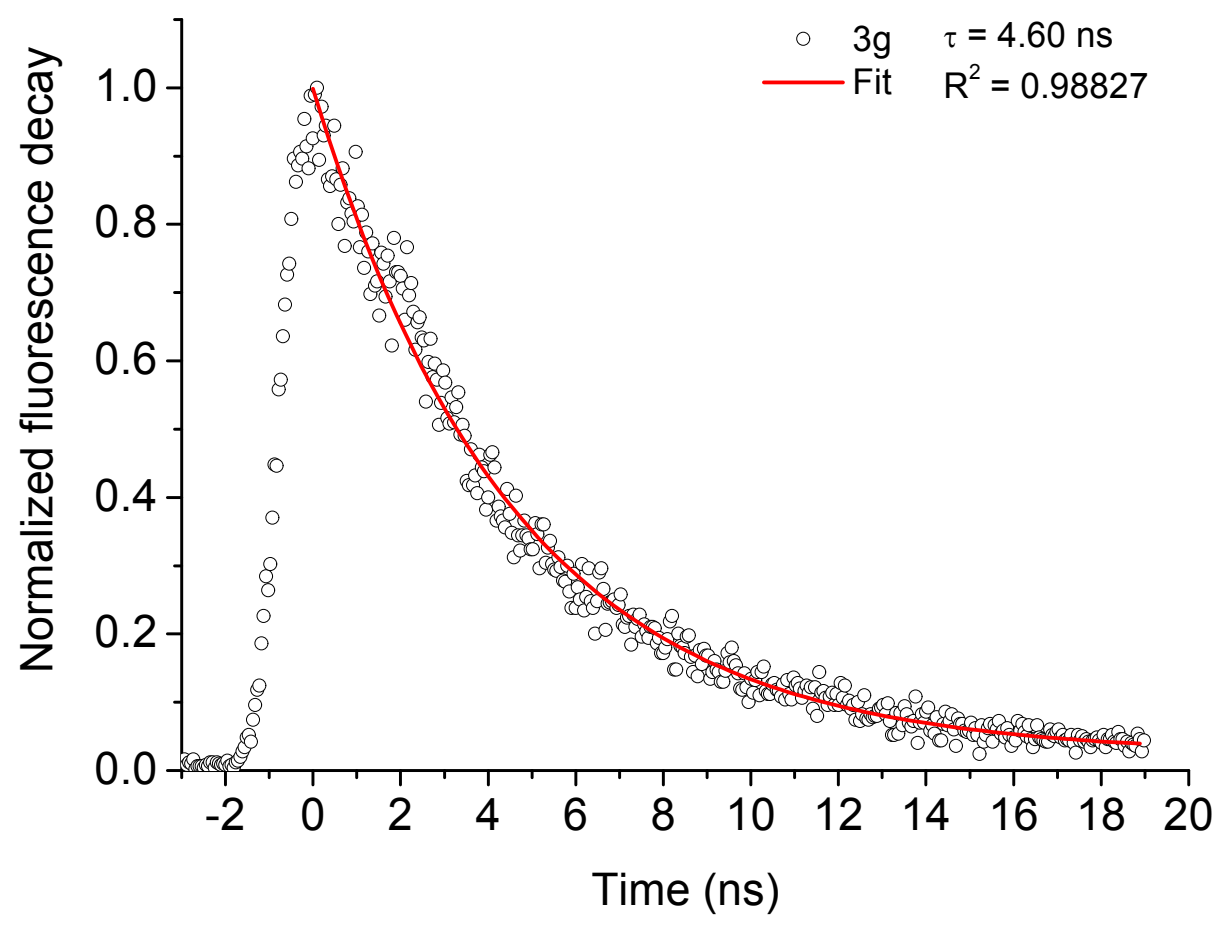

Figure S51. Fluorescence decay time of derivative $\mathbf{3 g}$ in $\mathrm{MeOH}$ solutions.

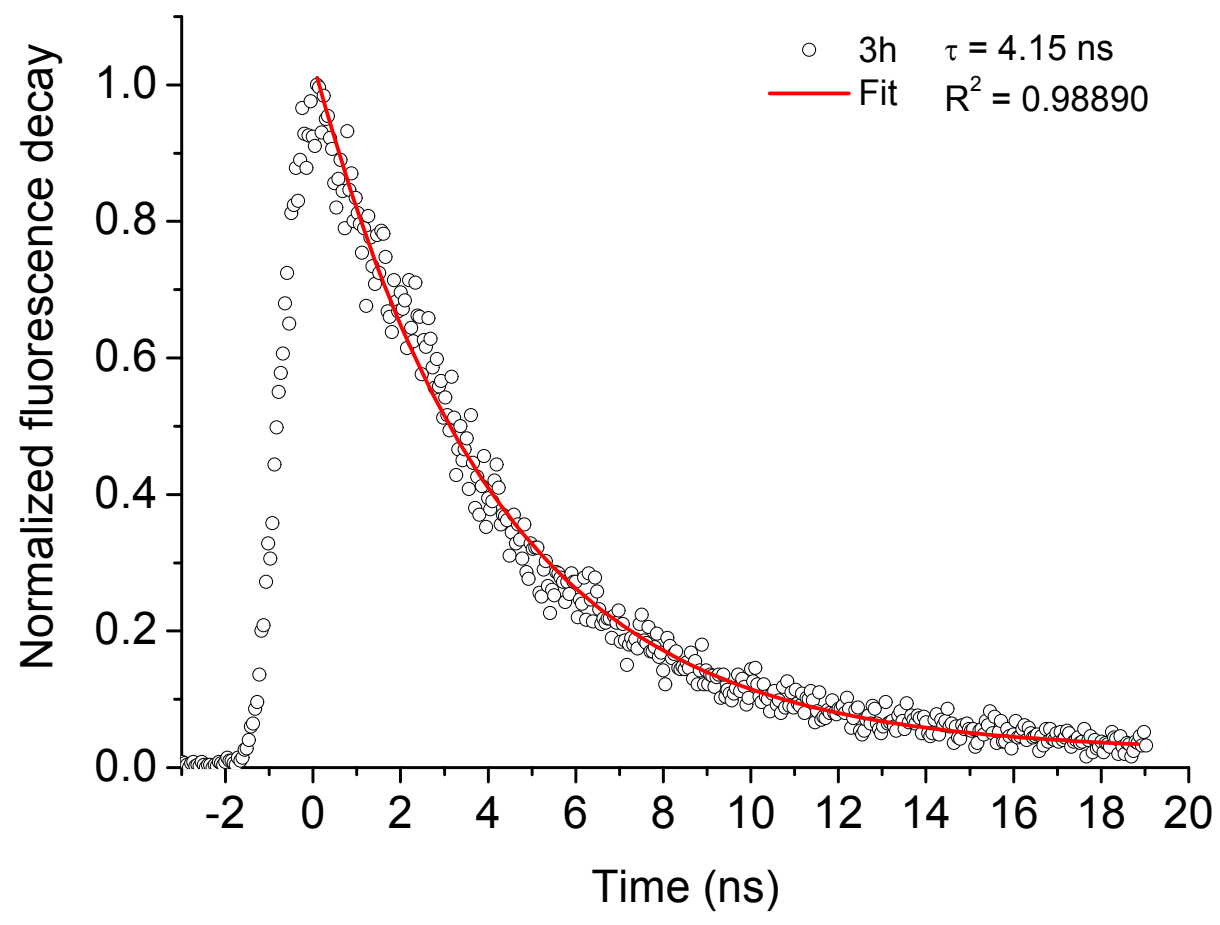

Figure S52. Fluorescence decay time of derivative $3 \mathrm{~h}$ in $\mathrm{MeOH}$ solutions. 


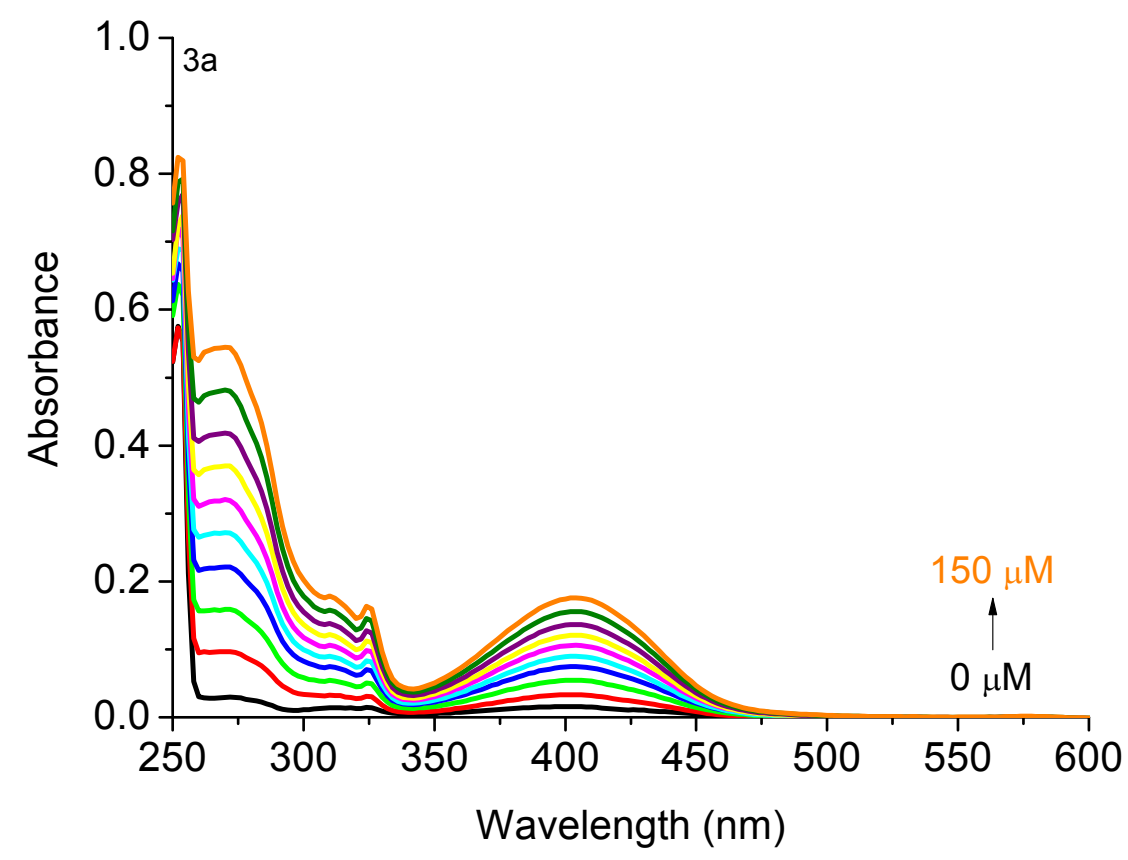

Figure S53. Aggregation study for compound 3a, using $\mathrm{DMSO}(5 \%) / \mathrm{Tris}-\mathrm{HCl} \mathrm{pH}$ 7.4 buffer solution as solvent. The inset shows the linear behavior of the absorbance at less energetic band as a function of the concentration.

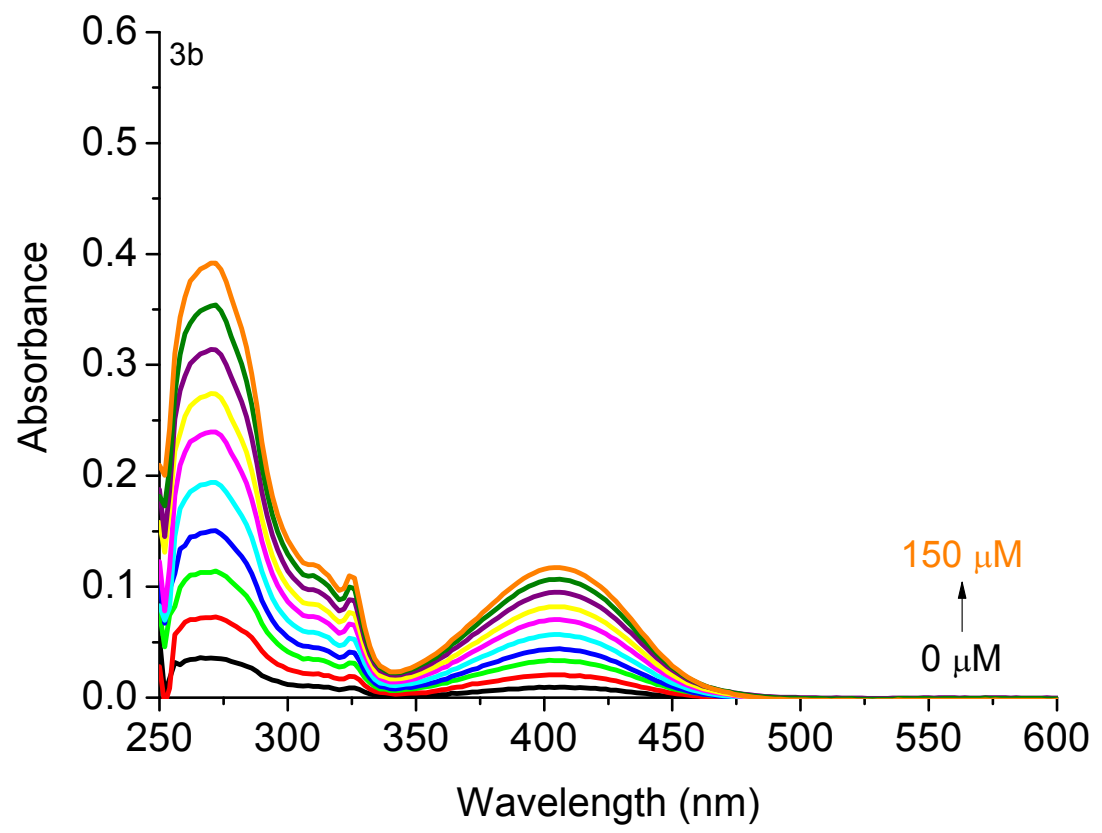

Figure S54. Aggregation study for compound $3 \mathbf{b}$, using $\mathrm{DMSO}(5 \%) / \mathrm{Tris}-\mathrm{HCl} \mathrm{pH}$ 7.4 buffer solution as solvent. The inset shows the linear behavior of the absorbance at less energetic band as a function of the concentration. 


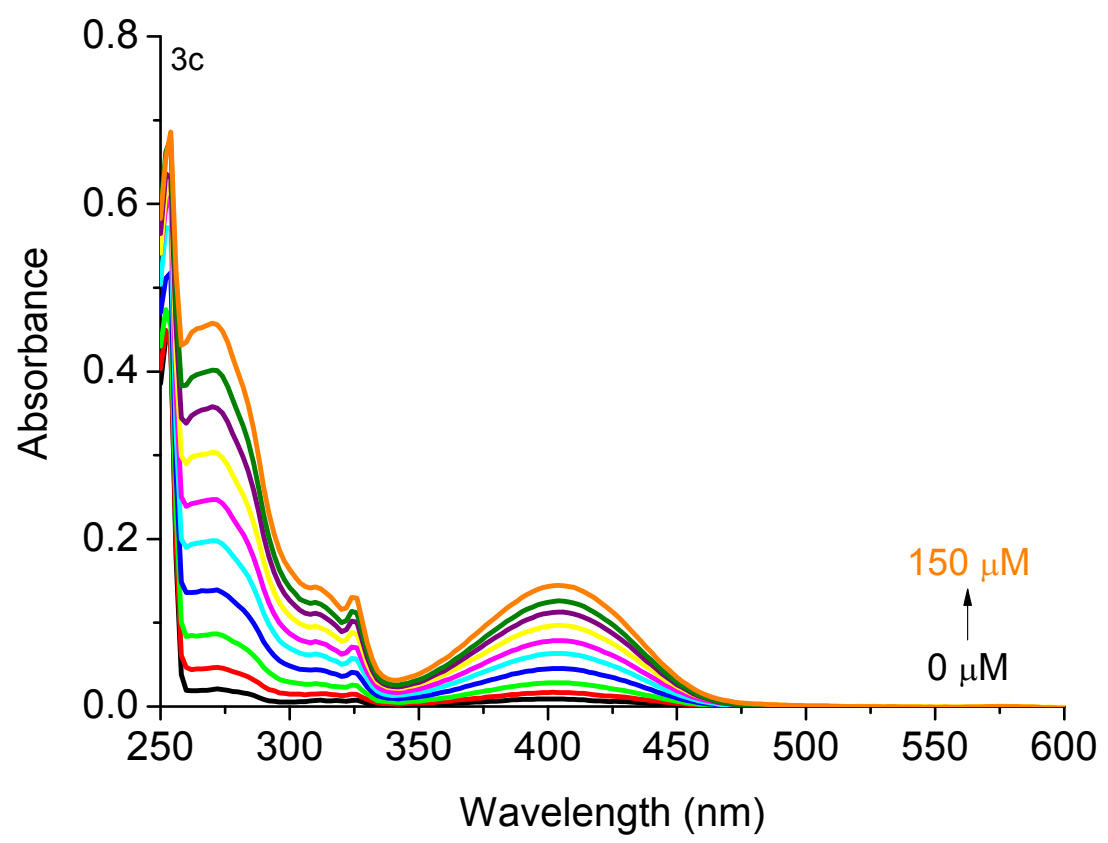

Figure S55. Aggregation study for compound 3c, using $\mathrm{DMSO}(5 \%) / \mathrm{Tris}-\mathrm{HCl} \mathrm{pH}$ 7.4 buffer solution as solvent. The inset shows the linear behavior of the absorbance at less energetic band as a function of the concentration.

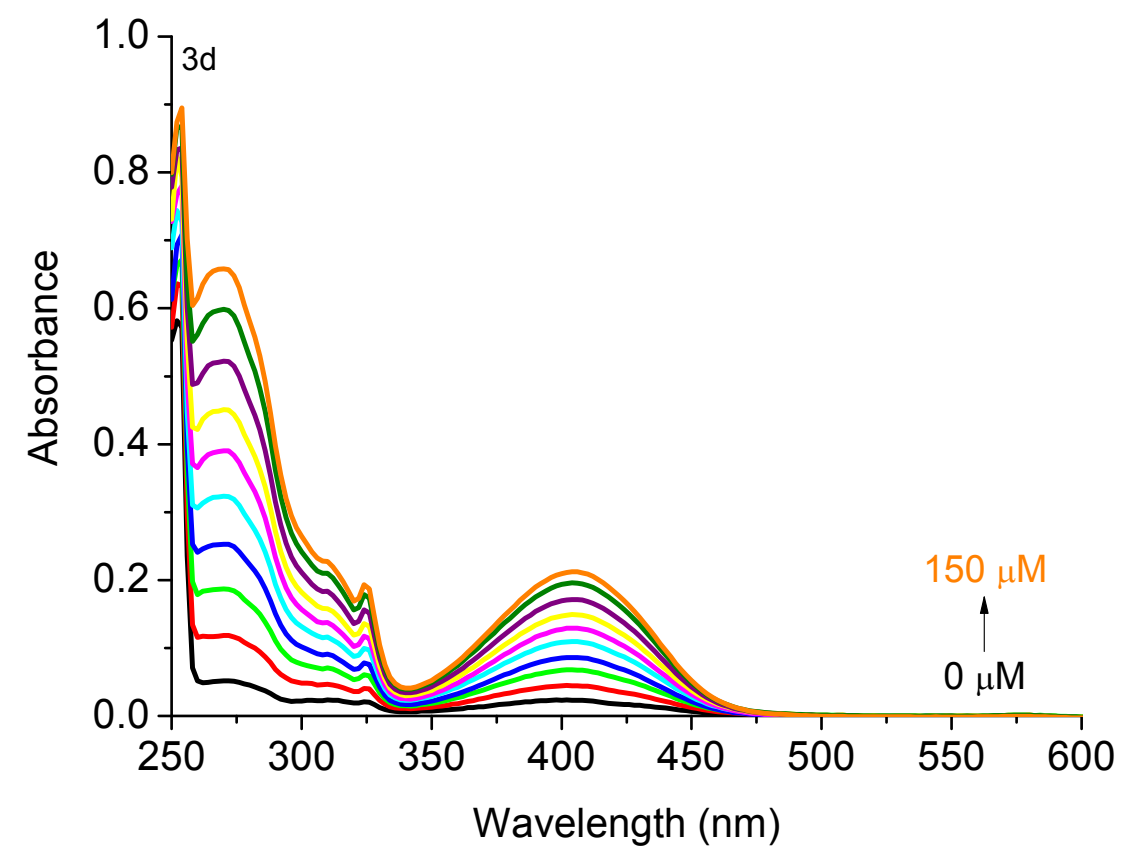

Figure S56. Aggregation study for compound 3d, using DMSO(5\%)/Tris- $\mathrm{HCl} \mathrm{pH}$ 7.4 buffer solution as solvent. The inset shows the linear behavior of the absorbance at less energetic band as a function of the concentration. 


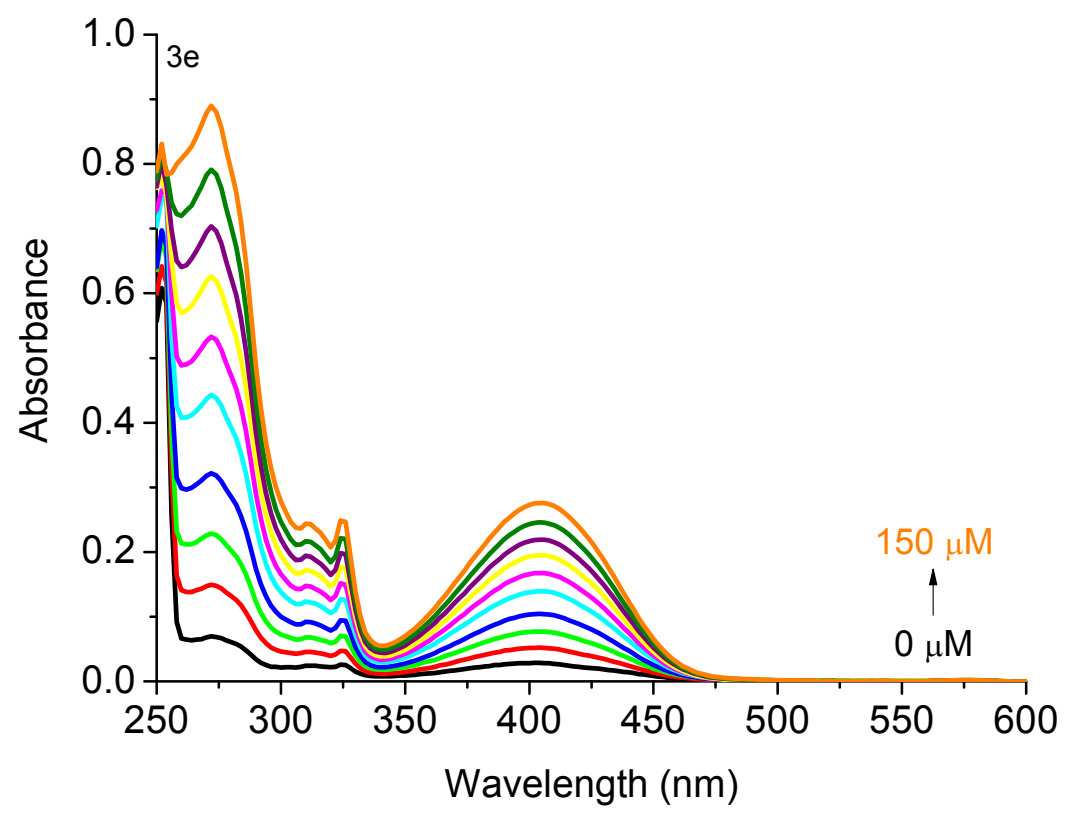

Figure S57. Aggregation study for compound 3e, using DMSO(5\%)/Tris- $\mathrm{HCl} \mathrm{pH}$ 7.4 buffer solution as solvent. The inset shows the linear behavior of the absorbance at less energetic band as a function of the concentration.

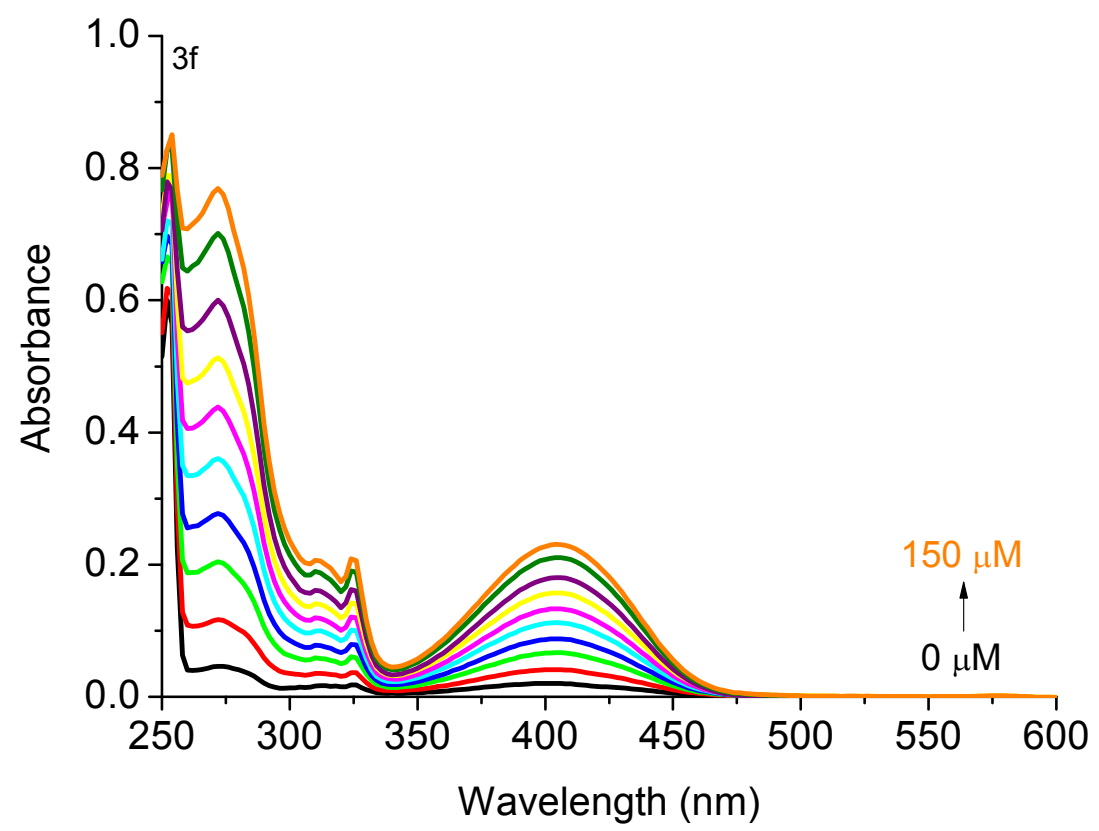

Figure S58. Aggregation study for compound $\mathbf{3 f}$, using $\mathrm{DMSO}(5 \%) / \mathrm{Tris}-\mathrm{HCl} \mathrm{pH}$ 7.4 buffer solution as solvent. The inset shows the linear behavior of the absorbance at less energetic band as a function of the concentration. 


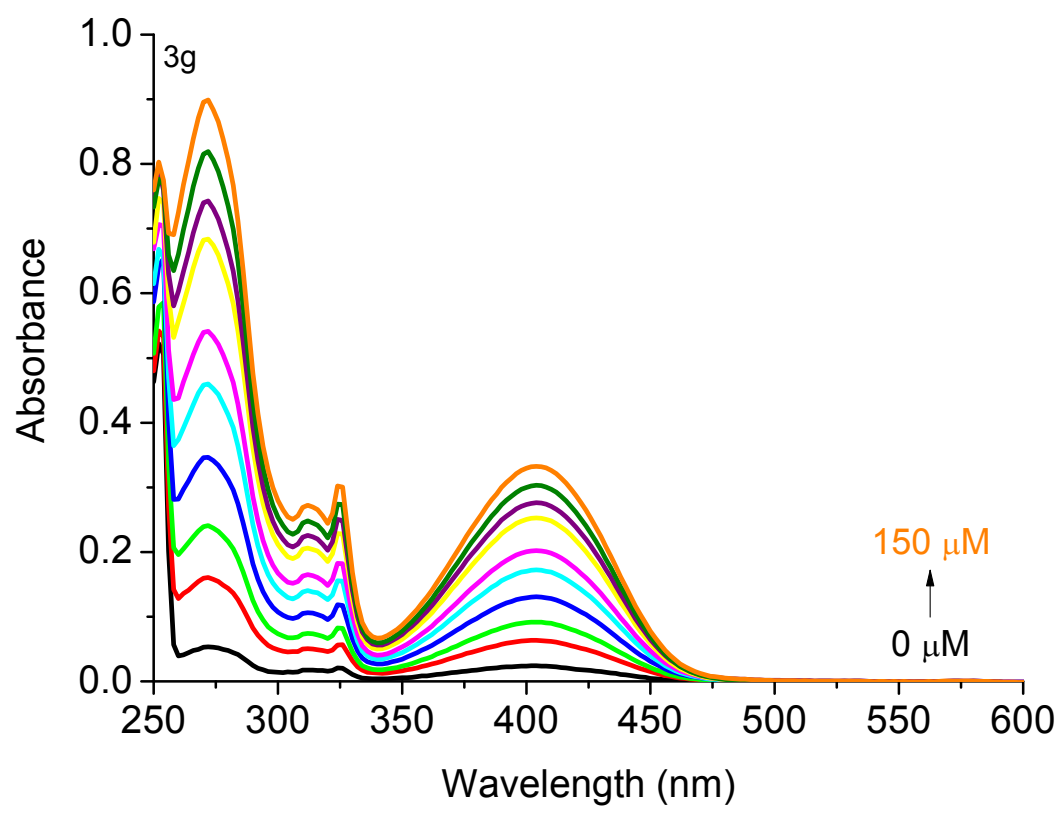

Figure S59. Aggregation study for compound $\mathbf{3 g}$, using DMSO(5\%)/Tris- $\mathrm{HCl} \mathrm{pH}$ 7.4 buffer solution as solvent. The inset shows the linear behavior of the absorbance at less energetic band as a function of the concentration.

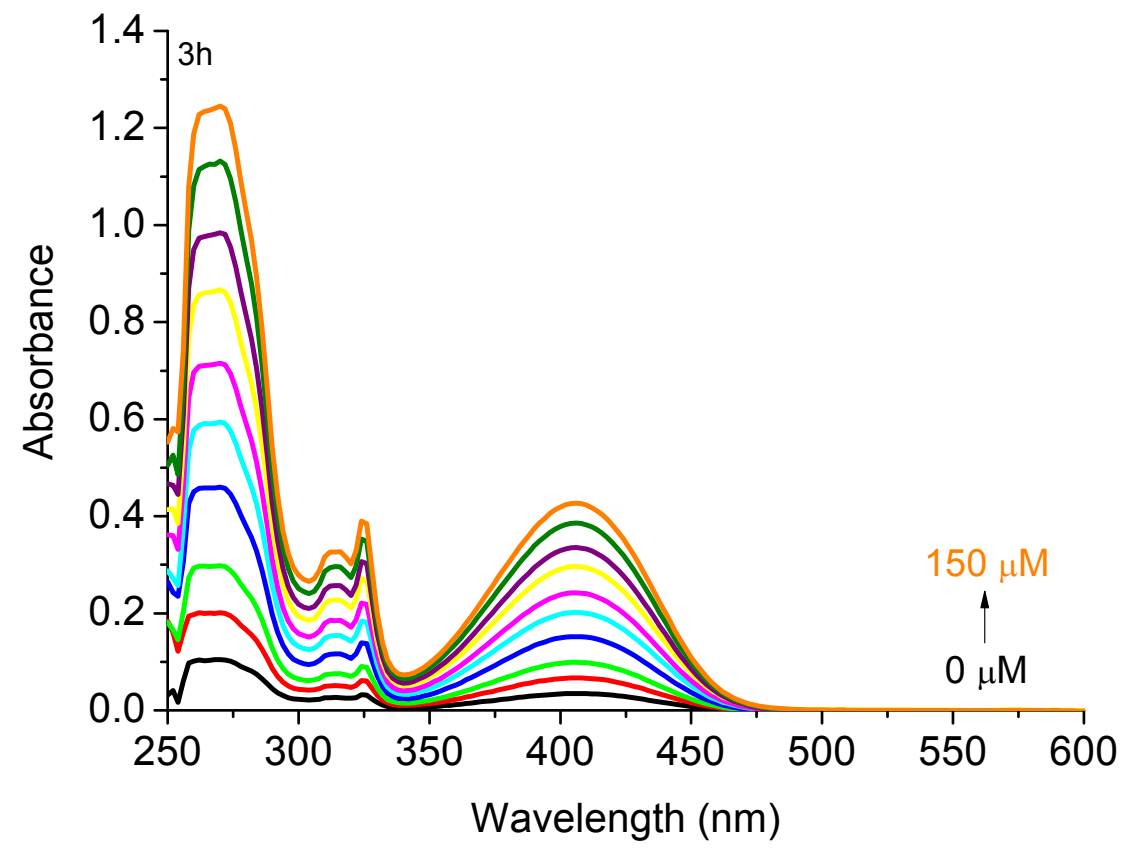

Figure S60. Aggregation study for compound $3 \mathbf{h}$, using $\mathrm{DMSO}(5 \%) / \mathrm{Tris}-\mathrm{HCl} \mathrm{pH}$ 7.4 buffer solution as solvent. The inset shows the linear behavior of the absorbance at less energetic band as a function of the concentration. 


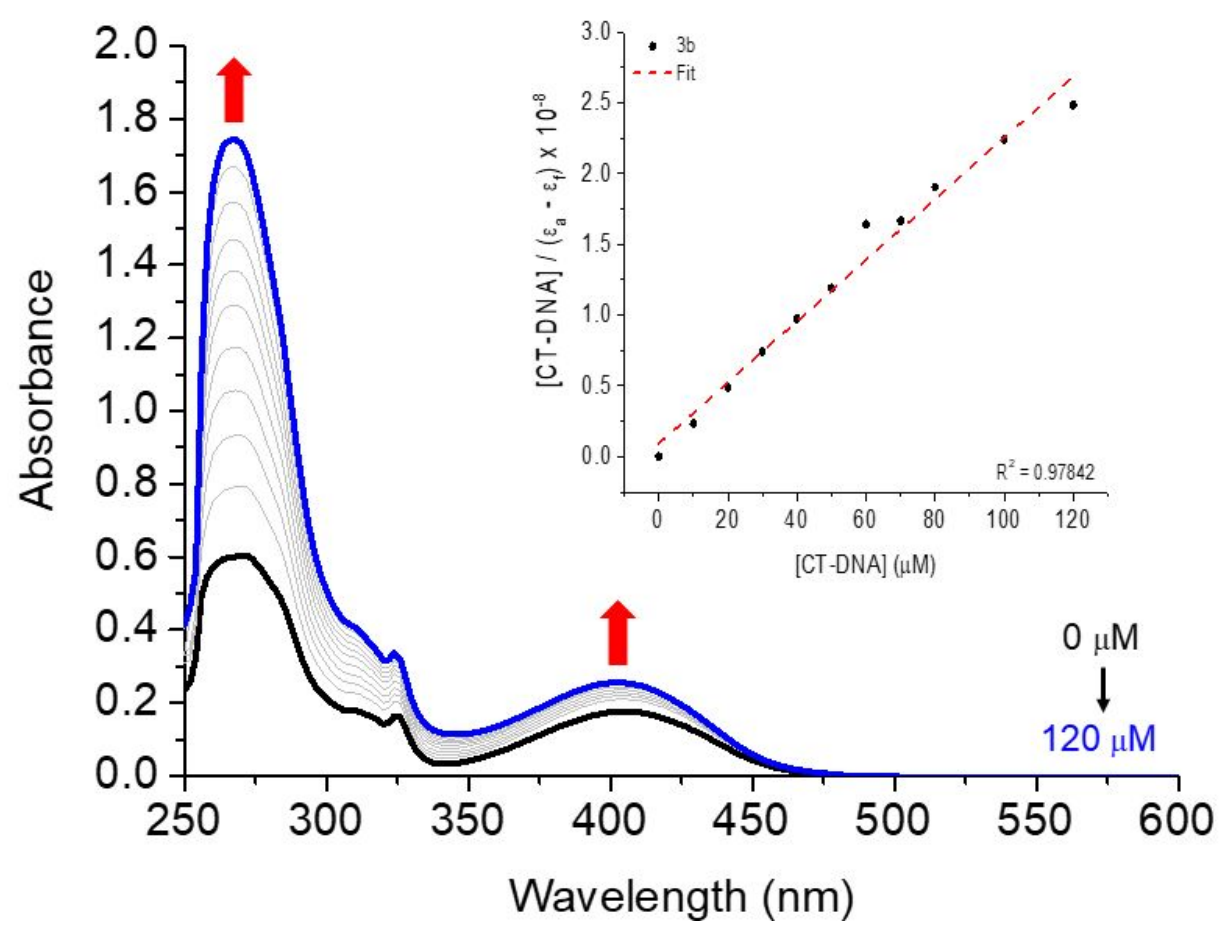

Figure S61. UV-Vis absorption spectra of compound $\mathbf{3 b}$ with increase CT-DNA concentrations, in a DMSO $(5 \%) / T$ ris- $\mathrm{HCl}$ buffer $(\mathrm{pH} 7.4)$ solution. The insert shows the plot of $[\mathrm{DNA}] /\left(\varepsilon_{\mathrm{a}}-\varepsilon_{\mathrm{f}}\right)$ versus [DNA]. The concentration of derivatives was fixed in $20 \mu \mathrm{M}$.

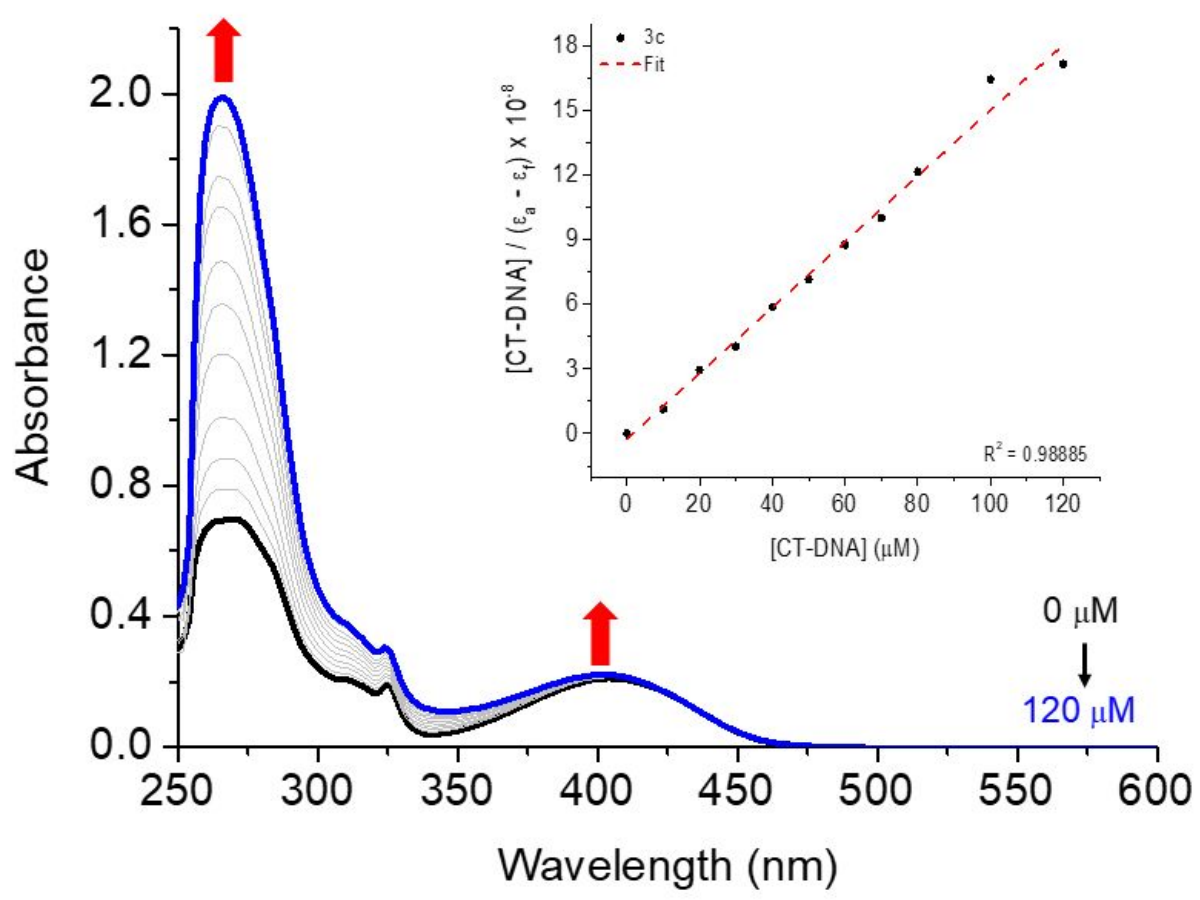

Figure S62. UV-Vis absorption spectra of compound 3c with increase CT-DNA concentrations, in a DMSO $(5 \%) / T$ ris- $\mathrm{HCl}$ buffer $(\mathrm{pH} 7.4)$ solution. The insert shows the plot of $[\mathrm{DNA}] /\left(\varepsilon_{\mathrm{a}}-\varepsilon_{\mathrm{f}}\right)$ versus [DNA]. The concentration of derivatives was fixed in $20 \mu \mathrm{M}$. 


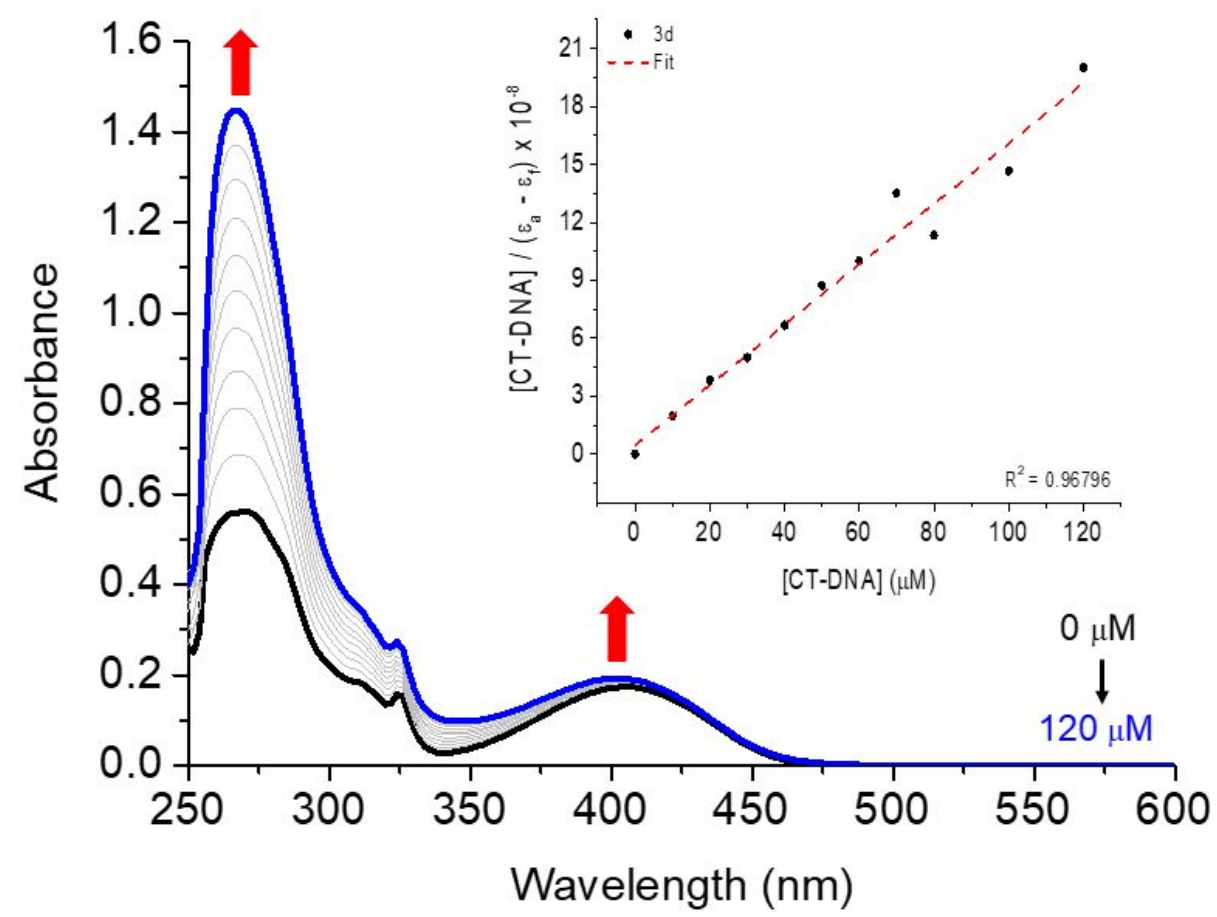

Figure S63. UV-Vis absorption spectra of compound 3d with increase CT-DNA concentrations, in a DMSO $(5 \%) / T$ ris- $\mathrm{HCl}$ buffer $(\mathrm{pH} 7.4)$ solution. The insert shows the plot of $[\mathrm{DNA}] /\left(\varepsilon_{\mathrm{a}}-\varepsilon_{\mathrm{f}}\right)$ versus [DNA]. The concentration of derivatives was fixed in $20 \mu \mathrm{M}$.

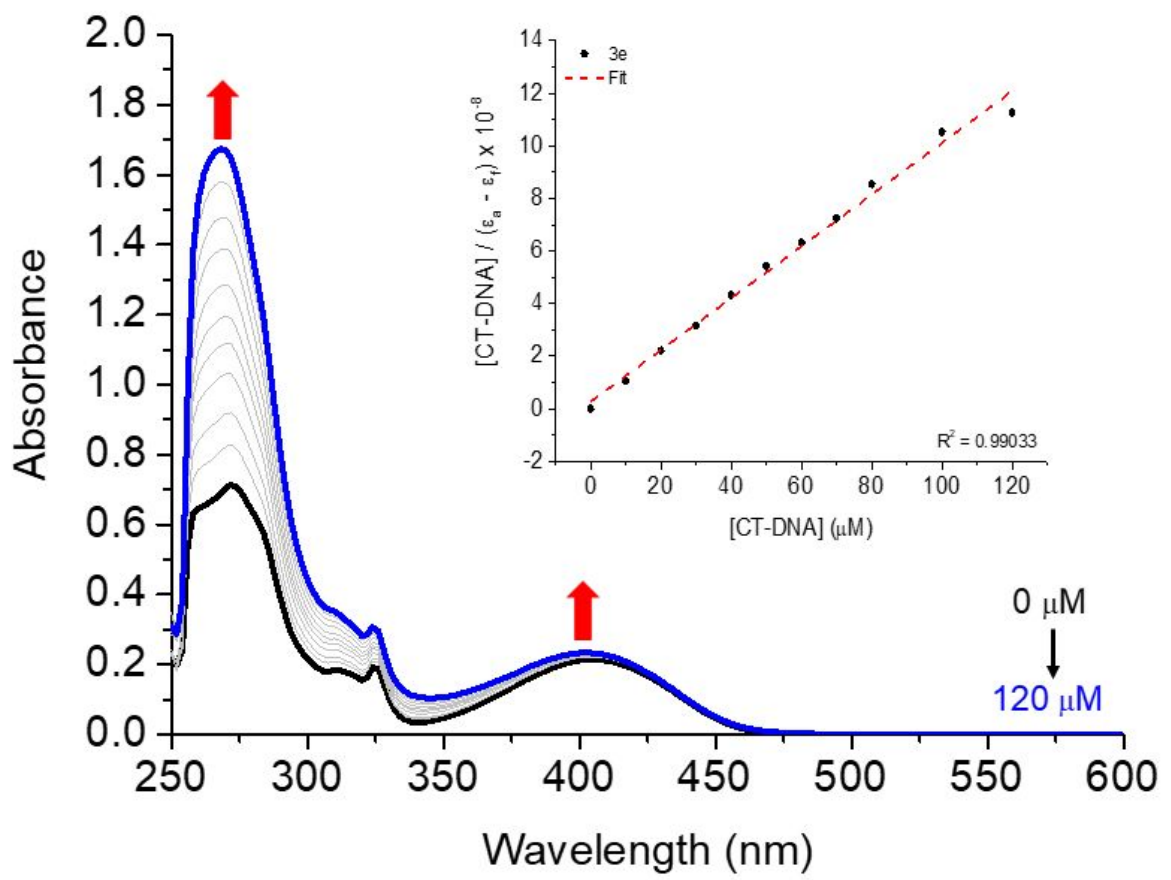

Figure S64. UV-Vis absorption spectra of compound 3e with increase CT-DNA concentrations, in a DMSO $(5 \%) / T$ ris- $\mathrm{HCl}$ buffer $(\mathrm{pH} 7.4)$ solution. The insert shows the plot of $[\mathrm{DNA}] /\left(\varepsilon_{\mathrm{a}}-\varepsilon_{\mathrm{f}}\right)$ versus [DNA]. The concentration of derivatives was fixed in $20 \mu \mathrm{M}$. 


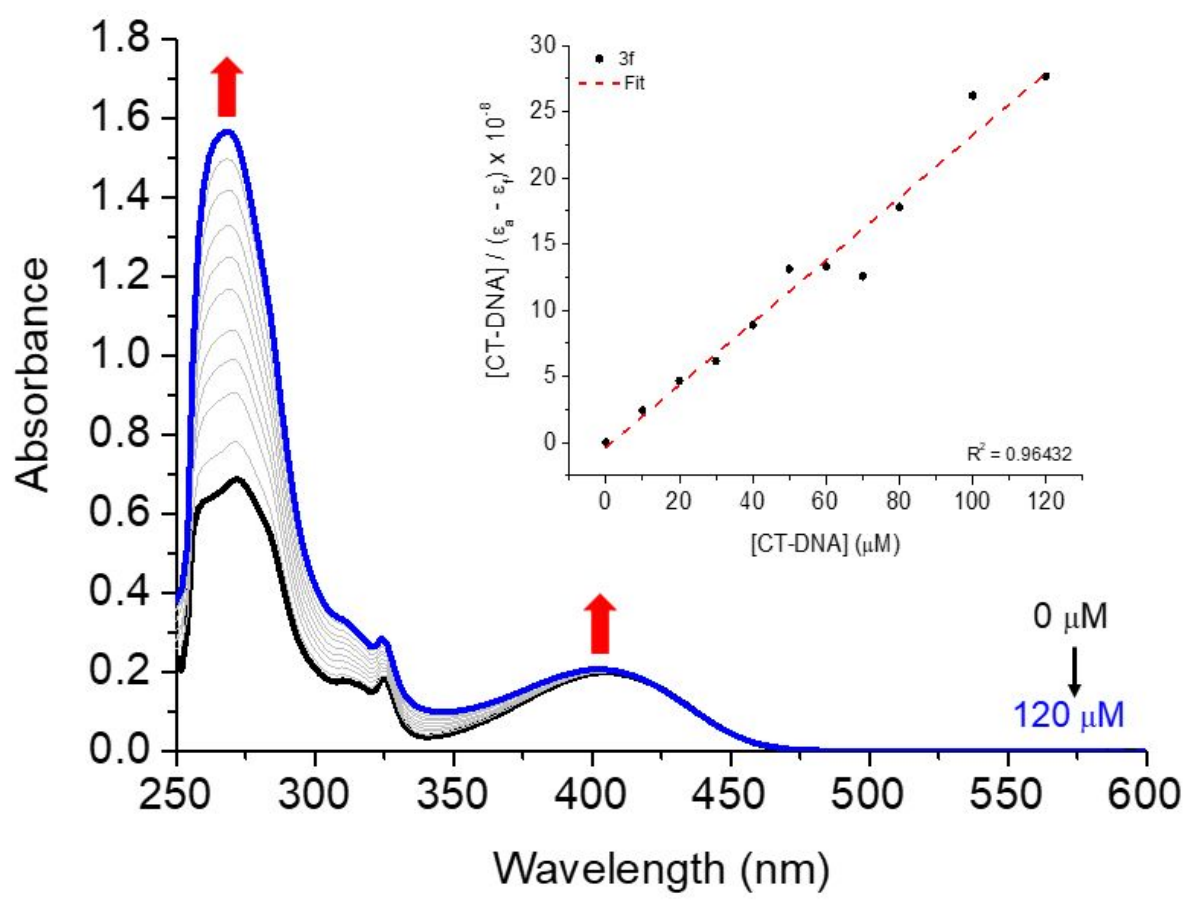

Figure S65. UV-Vis absorption spectra of compound $3 f$ with increase CT-DNA concentrations, in a DMSO $(5 \%) /$ Tris- $\mathrm{HCl}$ buffer $(\mathrm{pH} 7.4)$ solution. The insert shows the plot of $[\mathrm{DNA}] /\left(\varepsilon_{\mathrm{a}}-\varepsilon_{\mathrm{f}}\right)$ versus [DNA]. The concentration of derivatives was fixed in $20 \mu \mathrm{M}$.

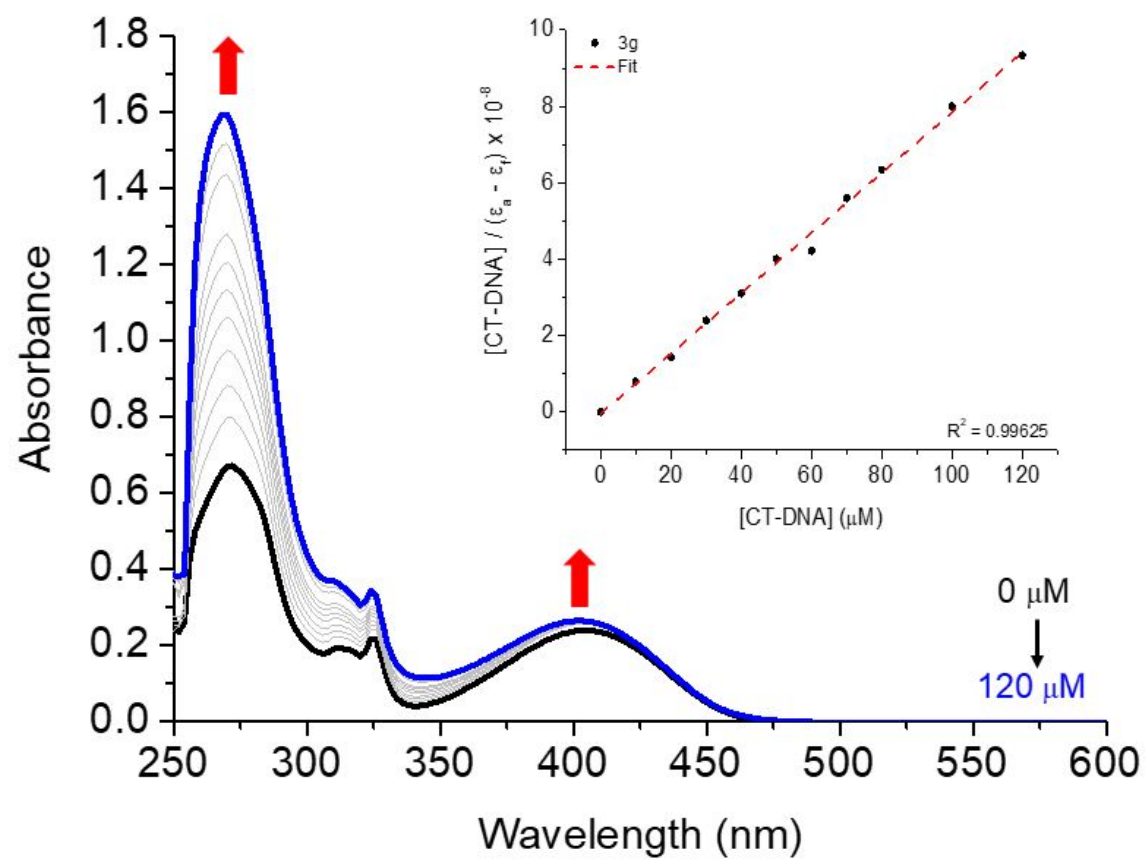

Figure S66. UV-Vis absorption spectra of compound $\mathbf{3 g}$ with increase CT-DNA concentrations, in a DMSO $(5 \%) / T$ ris- $\mathrm{HCl}$ buffer $(\mathrm{pH} 7.4)$ solution. The insert shows the plot of $[\mathrm{DNA}] /\left(\varepsilon_{\mathrm{a}}-\varepsilon_{\mathrm{f}}\right)$ versus [DNA]. The concentration of derivatives was fixed in $20 \mu \mathrm{M}$. 


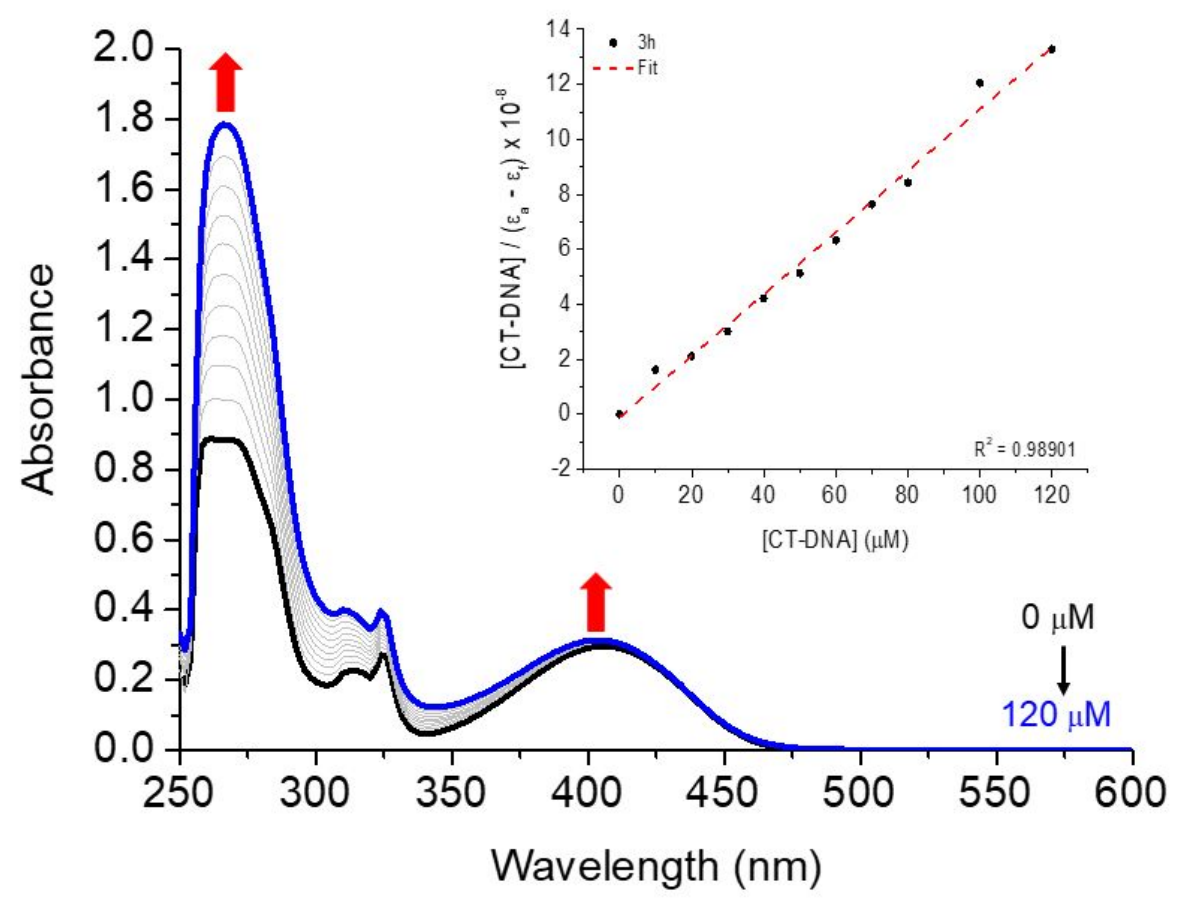

Figure S67. UV-Vis absorption spectra of compound $3 \mathrm{~h}$ with increase CT-DNA concentrations, in a DMSO $(5 \%) / T$ Tris- $\mathrm{HCl}$ buffer $(\mathrm{pH} 7.4)$ solution. The insert shows the plot of $[\mathrm{DNA}] /\left(\varepsilon_{\mathrm{a}}-\varepsilon_{\mathrm{f}}\right)$ versus [DNA]. The concentration of derivatives was fixed in $20 \mu \mathrm{M}$.

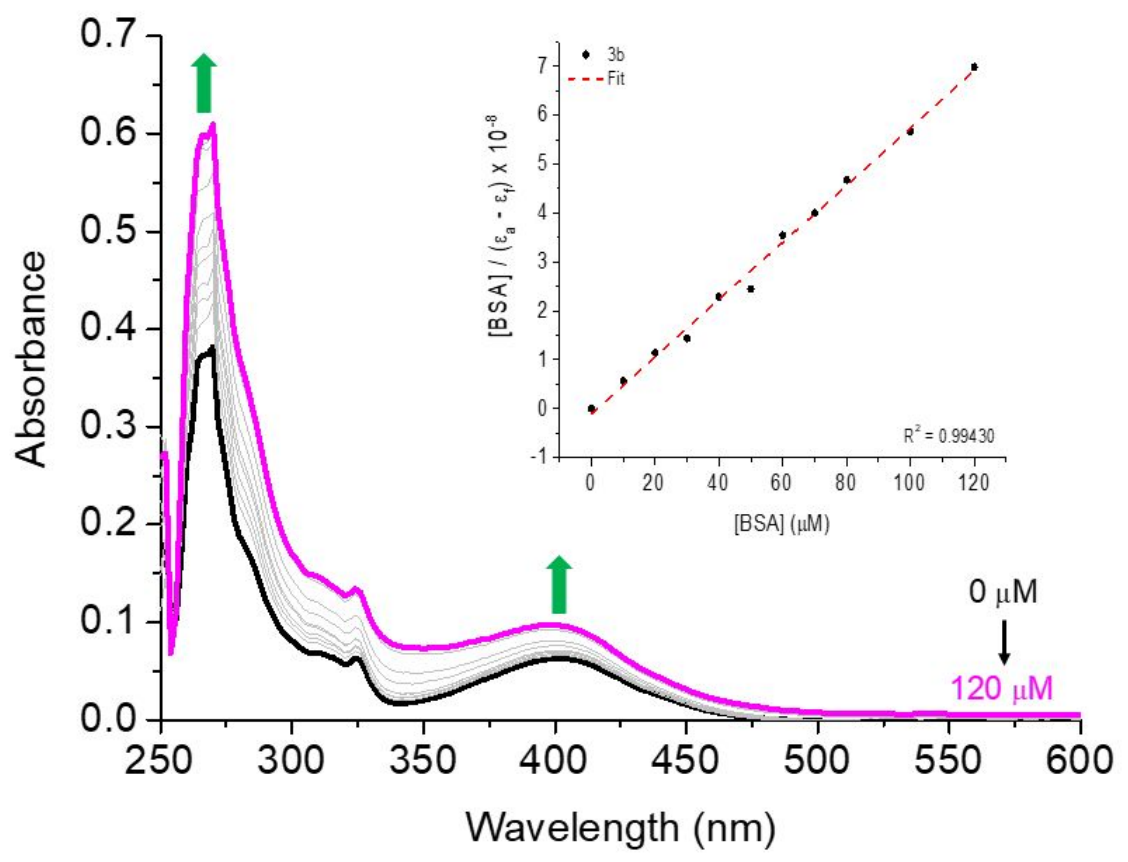

Figure S68. UV-Vis absorption spectra of compound $\mathbf{3 b}$ with increase BSA concentrations, in a DMSO $(5 \%) /$ Tris- $\mathrm{HCl}$ buffer $(\mathrm{pH} 7.4)$ solution. The insert shows the plot of $[B S A] /\left(\varepsilon_{a}-\varepsilon_{f}\right)$ versus $[B S A]$. The concentration of derivatives was fixed in $20 \mu \mathrm{M}$. 


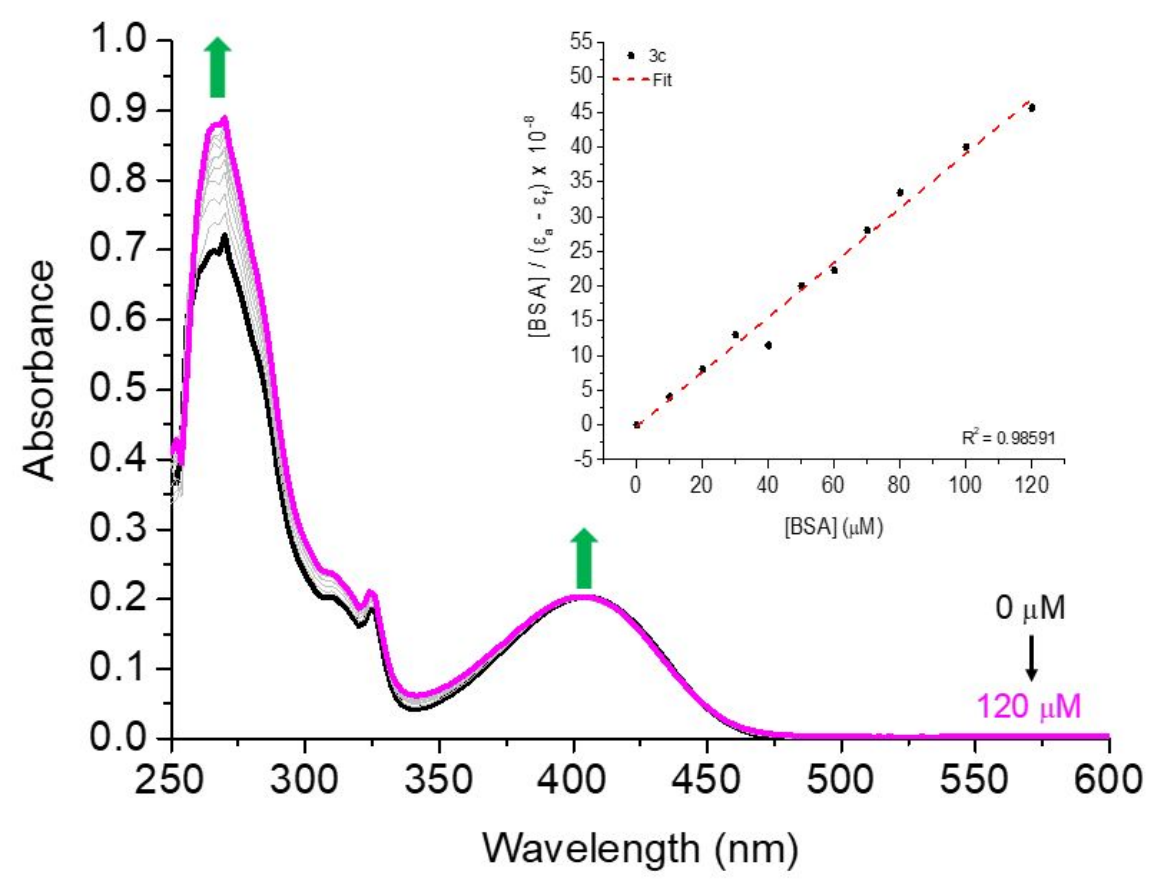

Figure S69. UV-Vis absorption spectra of compound 3c with increase BSA concentrations, in a DMSO(5\%)/Tris- $\mathrm{HCl}$ buffer $(\mathrm{pH} 7.4)$ solution. The insert shows the plot of $[B S A] /\left(\varepsilon_{a}-\varepsilon_{f}\right)$ versus $[B S A]$. The concentration of derivatives was fixed in $20 \mu \mathrm{M}$.

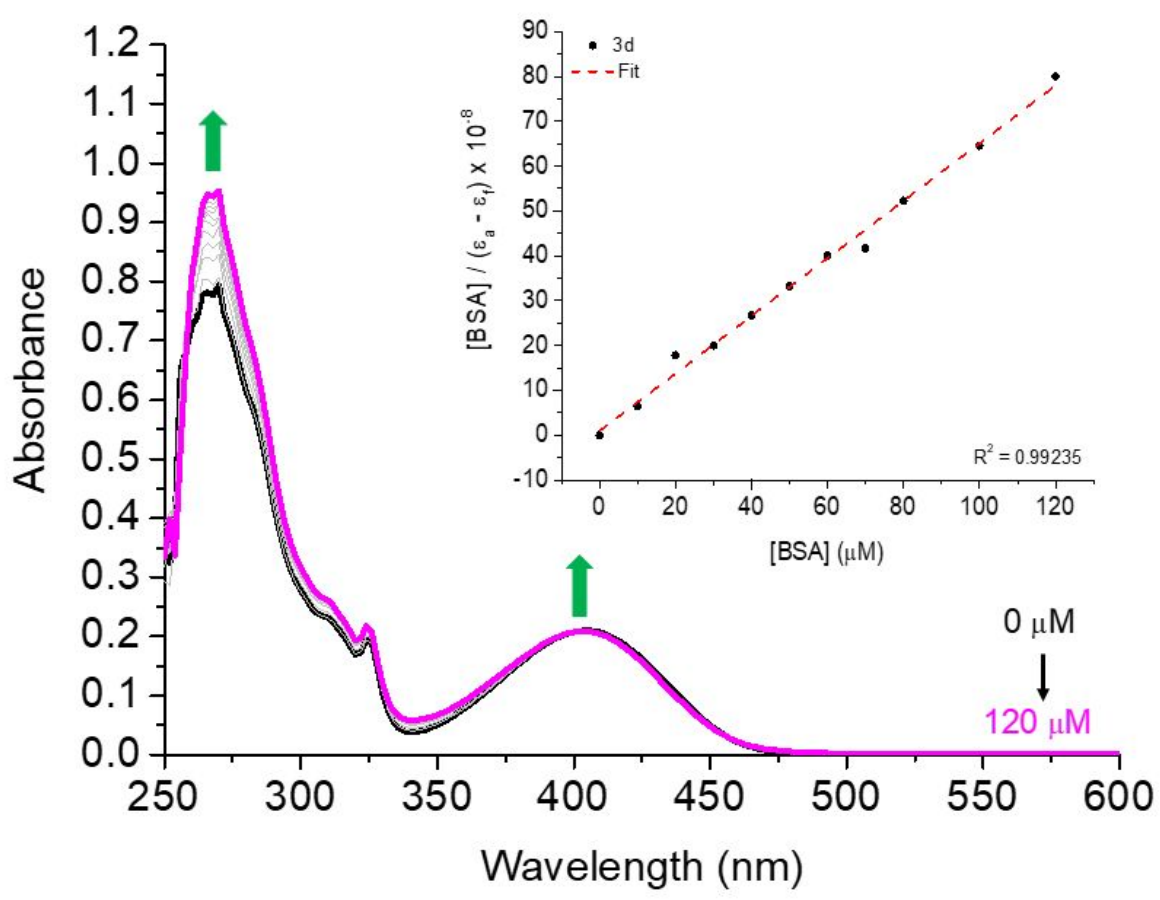

Figure S70. UV-Vis absorption spectra of compound 3d with increase BSA concentrations, in a DMSO $(5 \%) /$ Tris- $\mathrm{HCl}$ buffer $(\mathrm{pH} 7.4)$ solution. The insert shows the plot of $[B S A] /\left(\varepsilon_{a}-\varepsilon_{f}\right)$ versus $[B S A]$. The concentration of derivatives was fixed in $20 \mu \mathrm{M}$. 


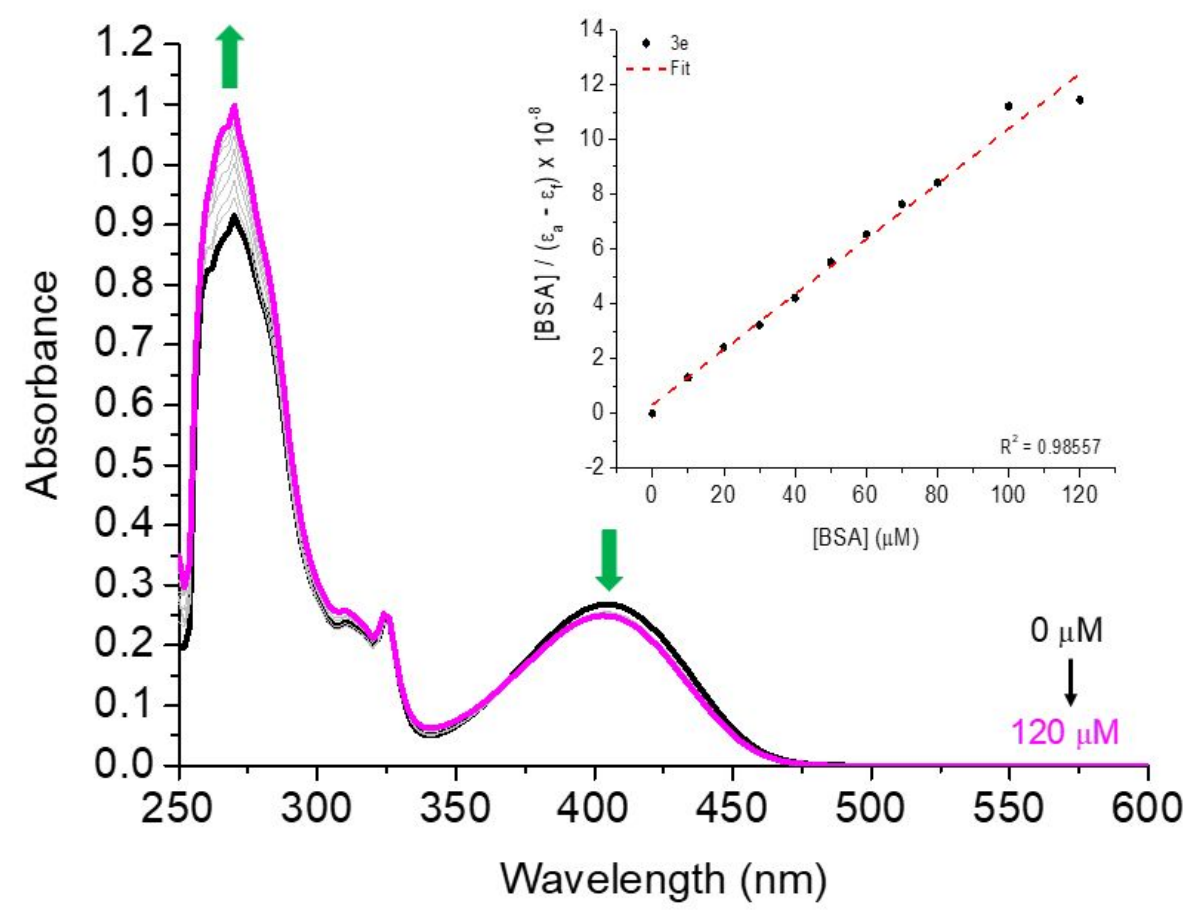

Figure S71. UV-Vis absorption spectra of compound 3e with increase BSA concentrations, in a DMSO(5\%)/Tris- $\mathrm{HCl}$ buffer $(\mathrm{pH} 7.4)$ solution. The insert shows the plot of $[B S A] /\left(\varepsilon_{a}-\varepsilon_{f}\right)$ versus $[B S A]$. The concentration of derivatives was fixed in $20 \mu \mathrm{M}$.

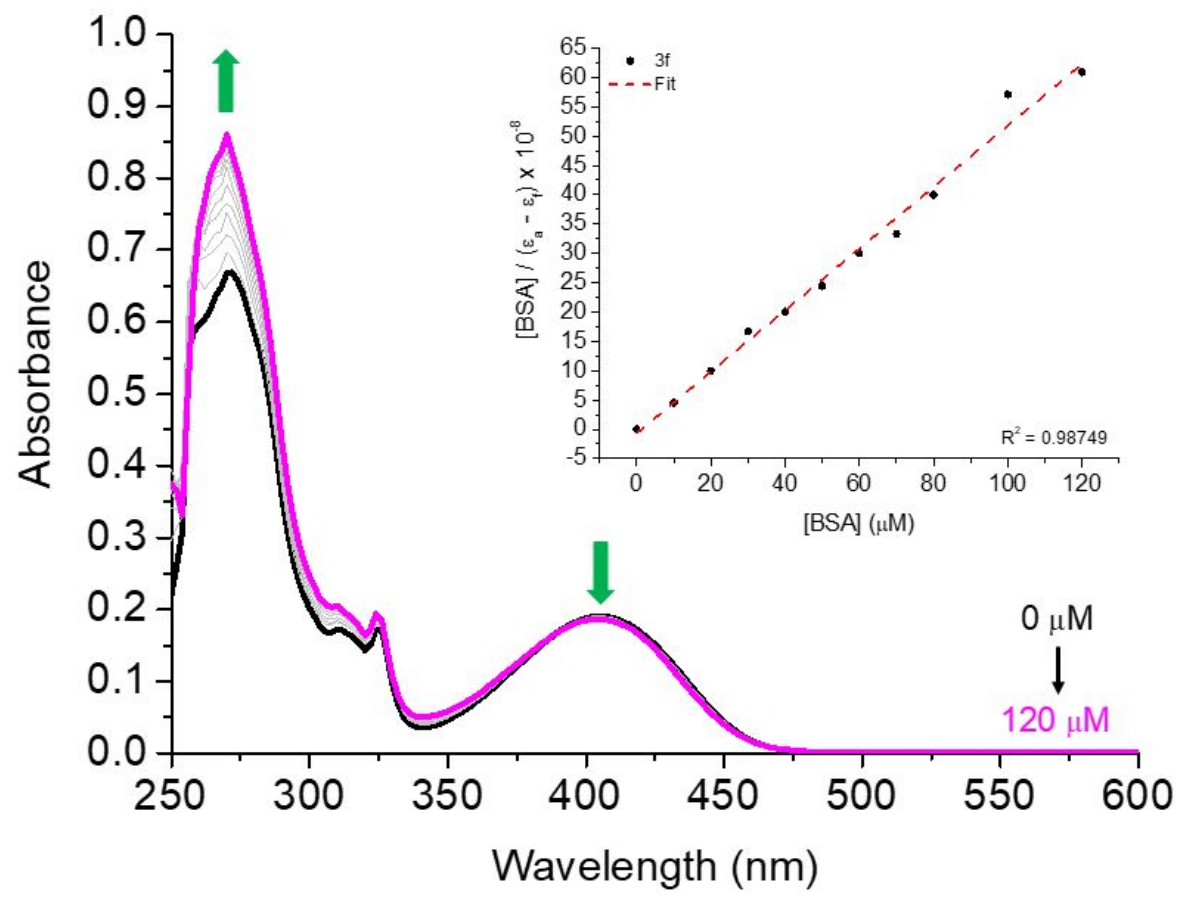

Figure S72. UV-Vis absorption spectra of compound $\mathbf{3 f}$ with increase BSA concentrations, in a DMSO $(5 \%) /$ Tris- $\mathrm{HCl}$ buffer $(\mathrm{pH} 7.4)$ solution. The insert shows the plot of $[B S A] /\left(\varepsilon_{a}-\varepsilon_{f}\right)$ versus $[B S A]$. The concentration of derivatives was fixed in $20 \mu \mathrm{M}$. 


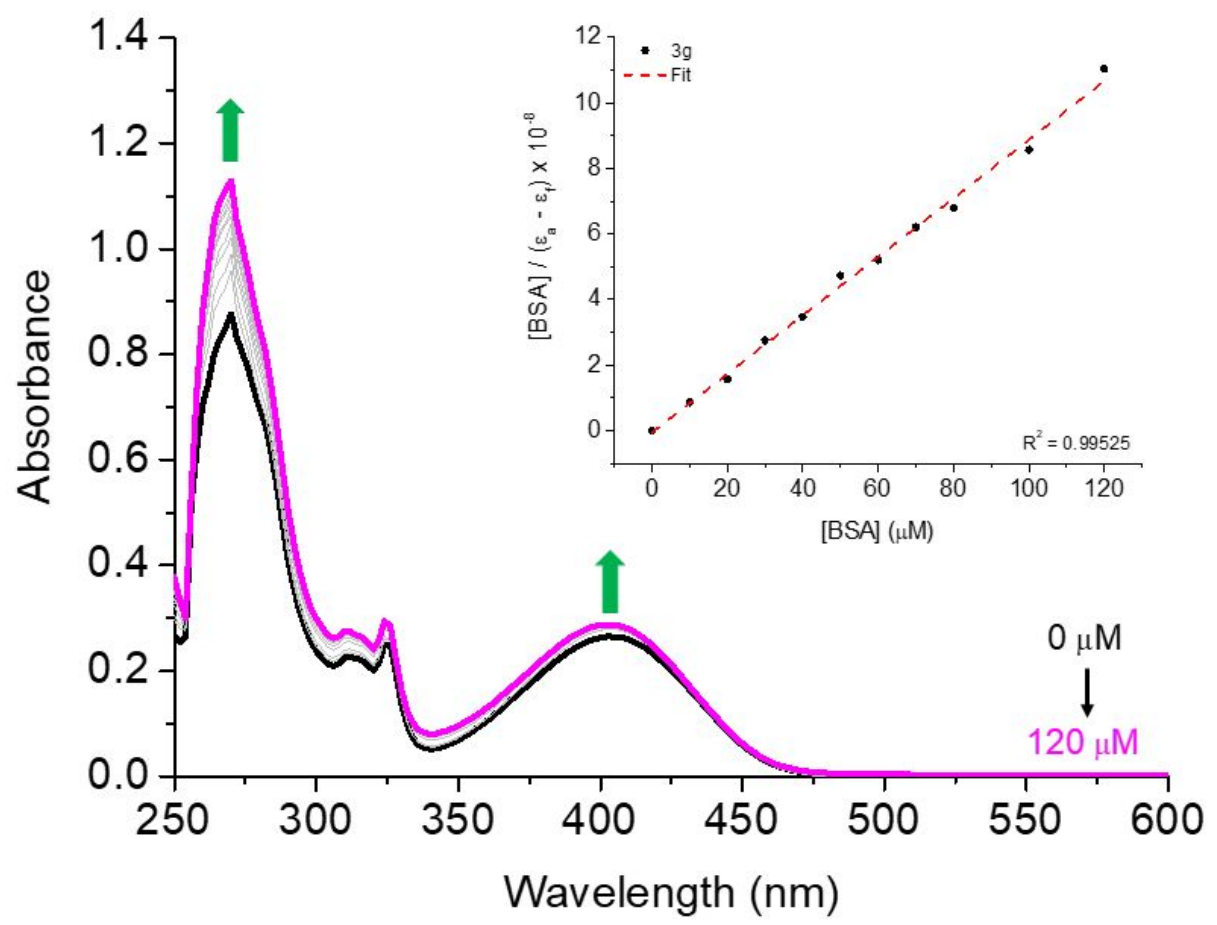

Figure S73. UV-Vis absorption spectra of compound $\mathbf{3 g}$ with increase BSA concentrations, in a DMSO(5\%)/Tris- $\mathrm{HCl}$ buffer $(\mathrm{pH} 7.4)$ solution. The insert shows the plot of $[\mathrm{BSA}] /\left(\varepsilon_{a}-\varepsilon_{f}\right)$ versus $[\mathrm{BSA}]$. The concentration of derivatives was fixed in $20 \mu \mathrm{M}$.

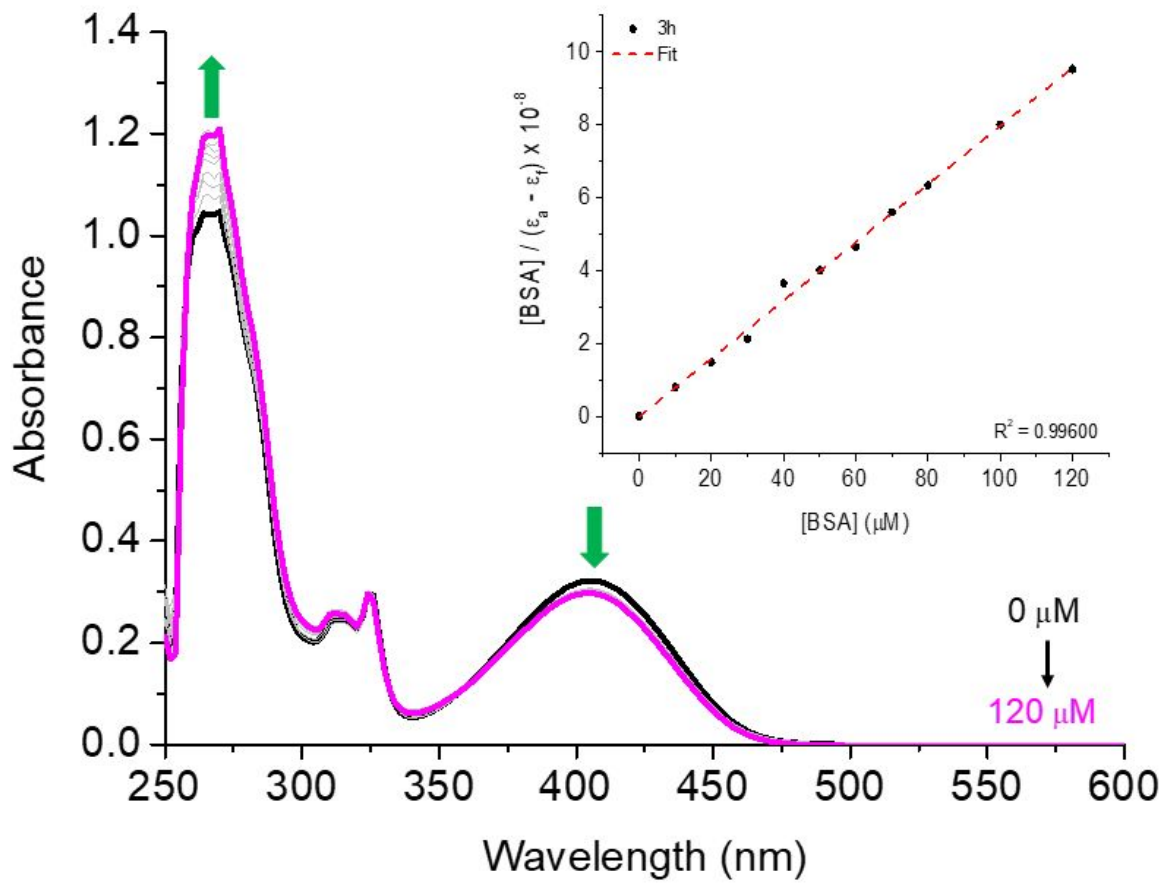

Figure S74. UV-Vis absorption spectra of compound $3 \mathrm{~h}$ with increase BSA concentrations, in a DMSO $(5 \%) /$ Tris- $\mathrm{HCl}$ buffer $(\mathrm{pH}$ 7.4) solution. The insert shows the plot of $[B S A] /\left(\varepsilon_{a}-\varepsilon_{f}\right)$ versus $[B S A]$. The concentration of derivatives was fixed in $20 \mu \mathrm{M}$. 


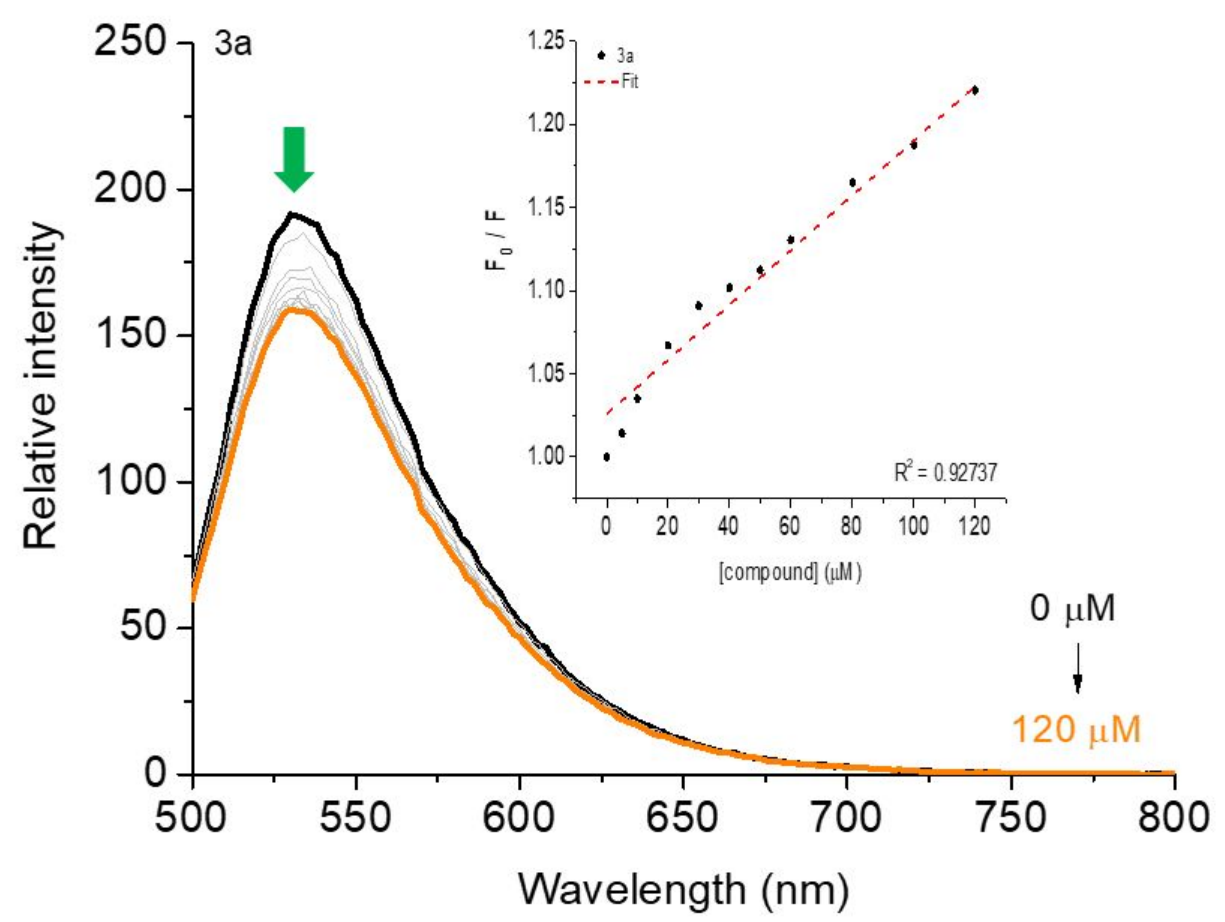

Figure S75. Emission fluorescence spectra of AO:DNA adduct with increase concentrations of derivative $3 \mathbf{a}$, in a $\mathrm{DMSO}(5 \%) / T$ ris- $\mathrm{HCl}$ buffer $(\mathrm{pH} 7.4)$ solution (excitation at $481 \mathrm{~nm}$ ). The insert shows the plot of $\mathrm{F}_{0} / \mathrm{F}$ versus [compound].

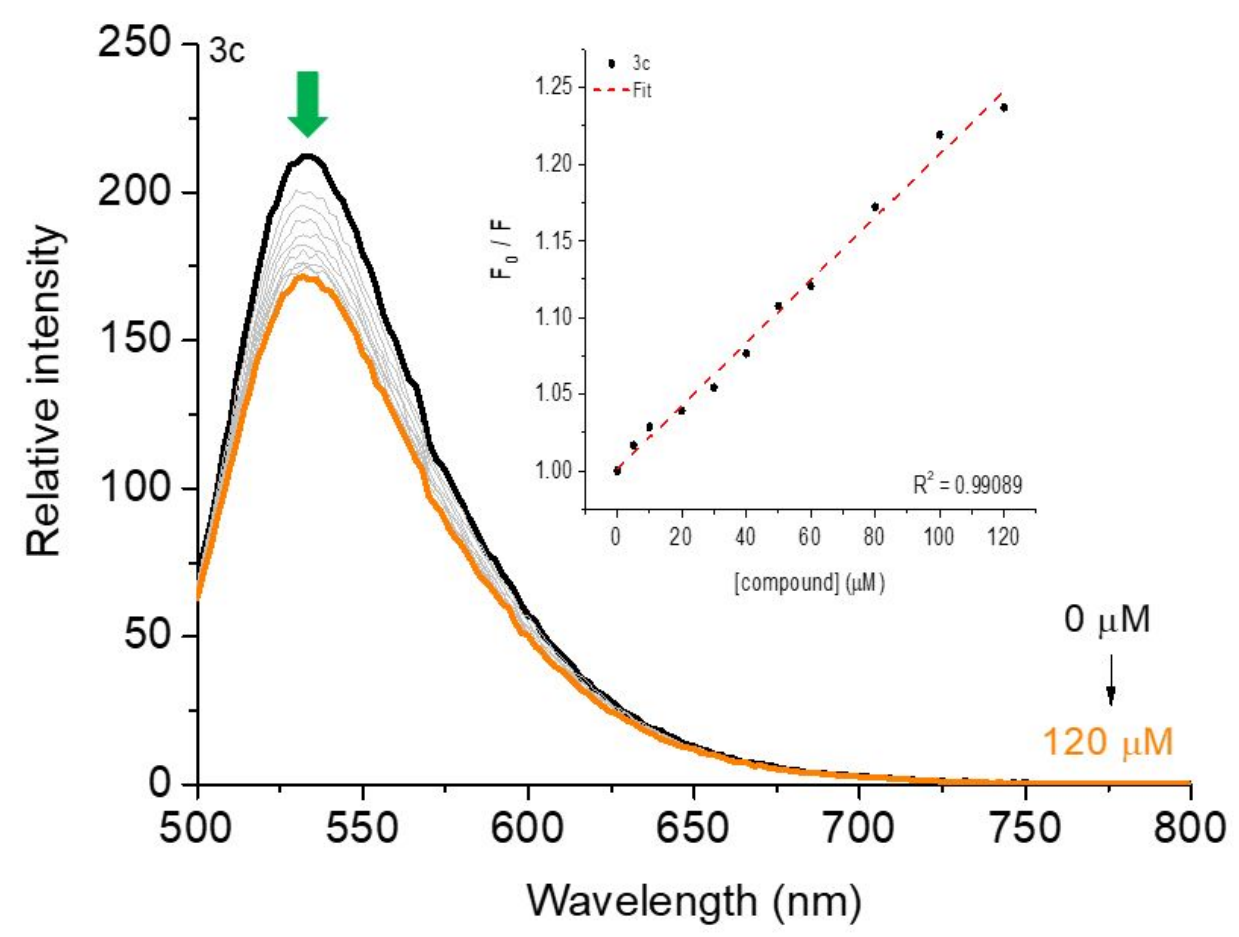

Figure S76. Emission fluorescence spectra of AO:DNA adduct with increase concentrations of derivative $3 \mathrm{c}$, in a $\mathrm{DMSO}(5 \%) / T$ ris- $\mathrm{HCl}$ buffer $(\mathrm{pH} 7.4)$ solution (excitation at $481 \mathrm{~nm}$ ). The insert shows the plot of $F_{0} / F$ versus [compound]. 


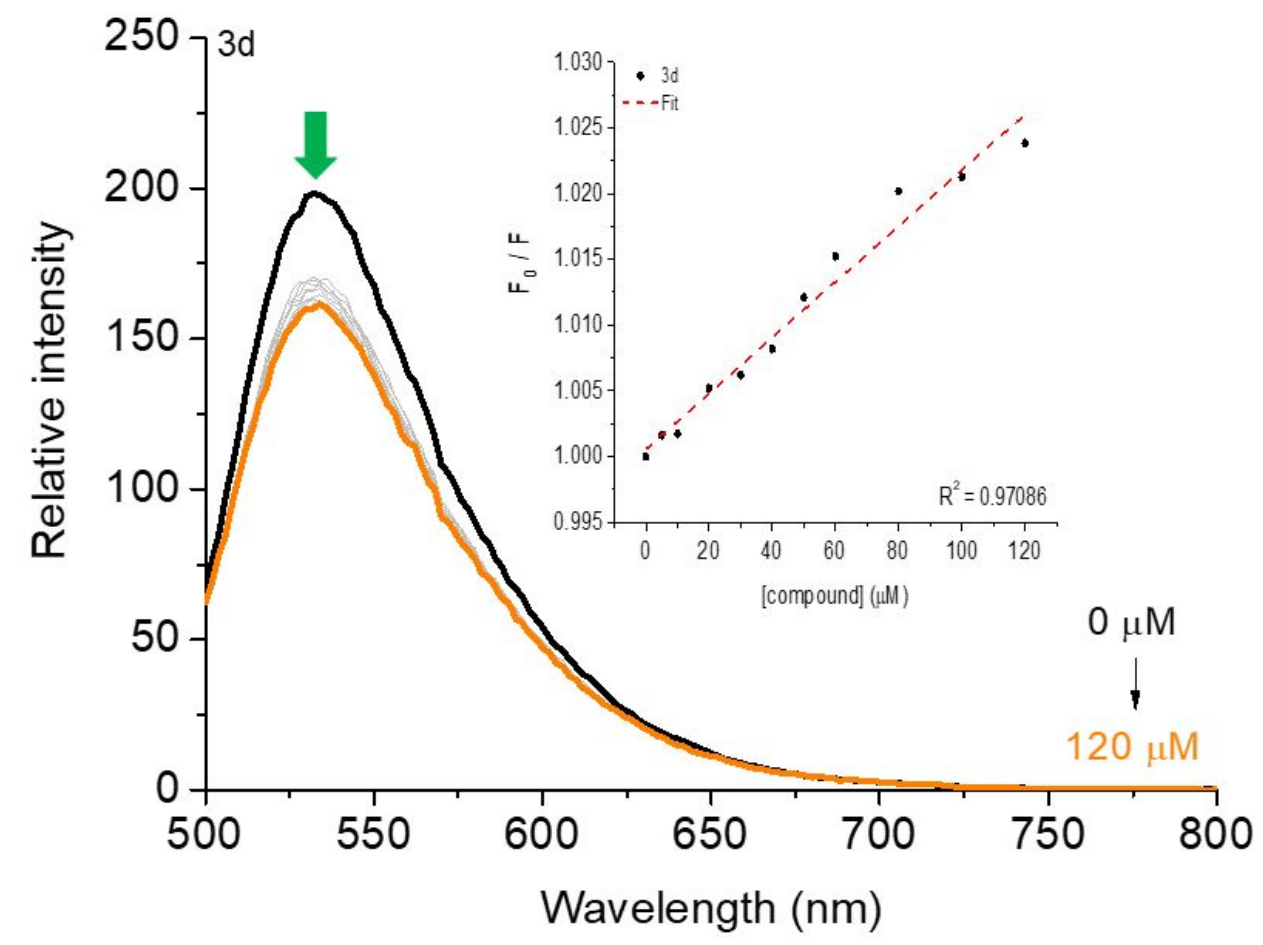

Figure S77. Emission fluorescence spectra of AO:DNA adduct with increase concentrations of derivative $3 \mathbf{d}$, in a $\mathrm{DMSO}(5 \%) / T$ ris- $\mathrm{HCl}$ buffer $(\mathrm{pH} 7.4)$ solution (excitation at $481 \mathrm{~nm}$ ). The insert shows the plot of $\mathrm{F}_{0} / \mathrm{F}$ versus [compound].

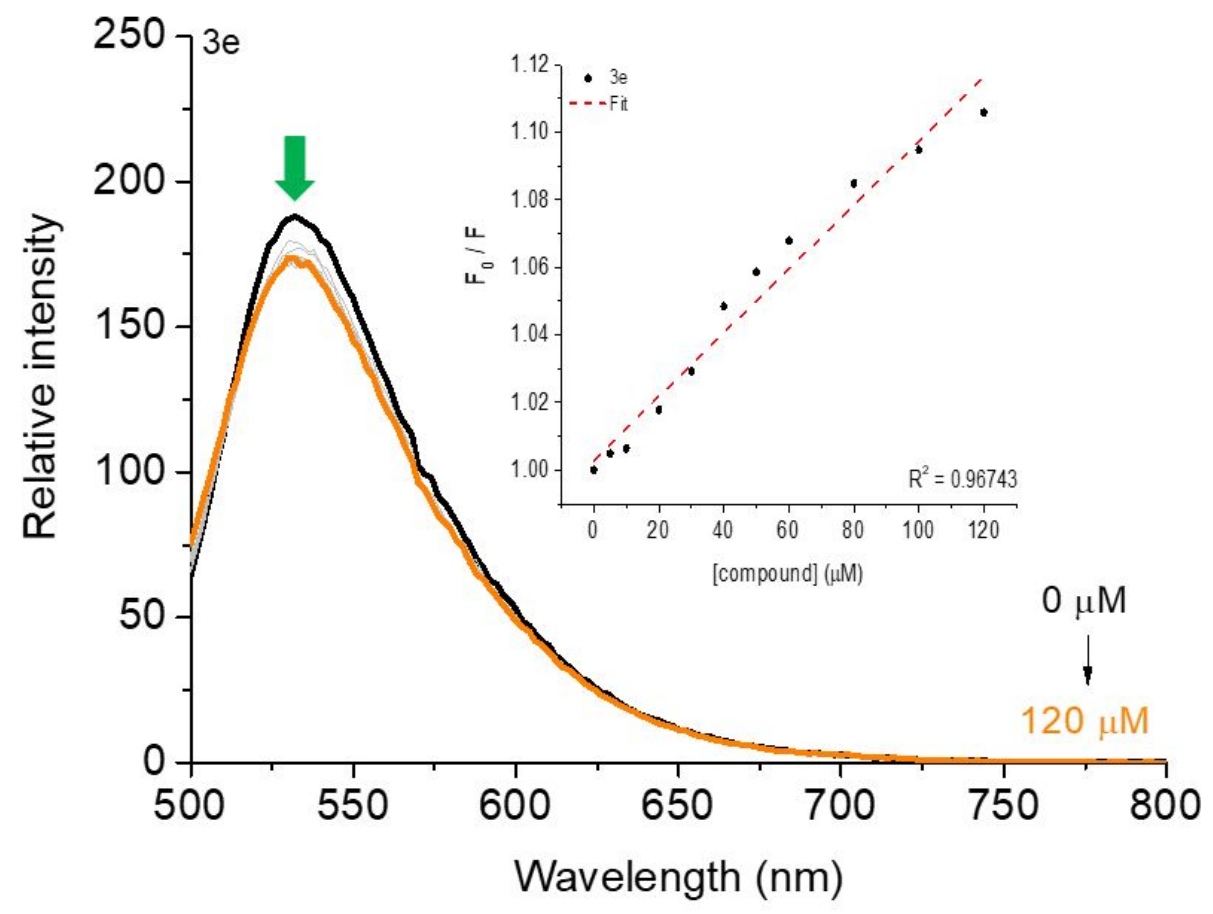

Figure S78. Emission fluorescence spectra of AO:DNA adduct with increase concentrations of derivative $3 \mathbf{e}$, in a $\mathrm{DMSO}(5 \%) / T$ ris- $\mathrm{HCl}$ buffer $(\mathrm{pH} 7.4)$ solution (excitation at $481 \mathrm{~nm}$ ). The insert shows the plot of $\mathrm{F}_{0} / \mathrm{F}$ versus [compound]. 


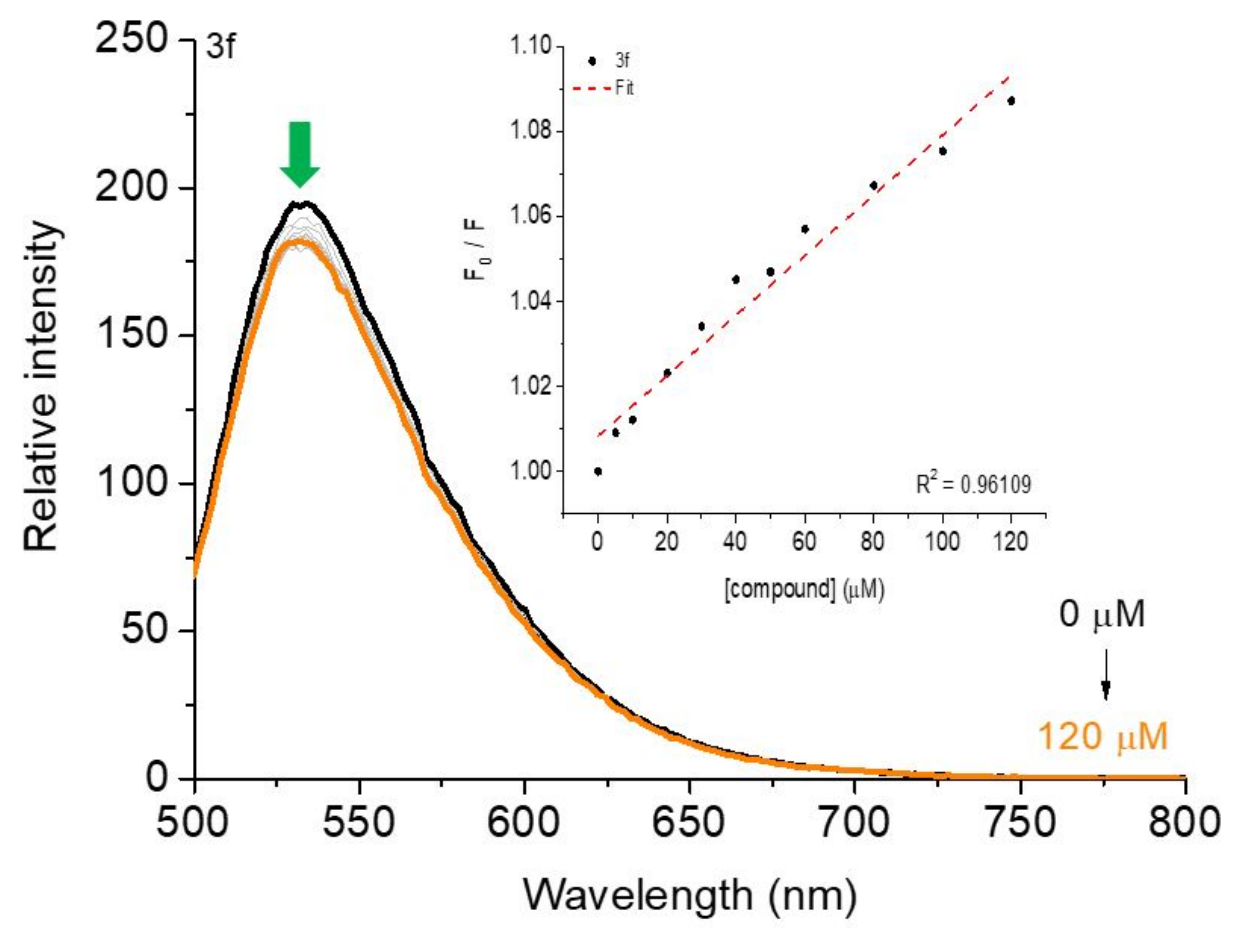

Figure S79. Emission fluorescence spectra of AO:DNA adduct with increase concentrations of derivative $\mathbf{3 f}$, in a $\mathrm{DMSO}(5 \%) /$ Tris-HCl buffer $(\mathrm{pH} 7.4)$ solution (excitation at $481 \mathrm{~nm}$ ). The insert shows the plot of $\mathrm{F}_{0} / \mathrm{F}$ versus [compound].

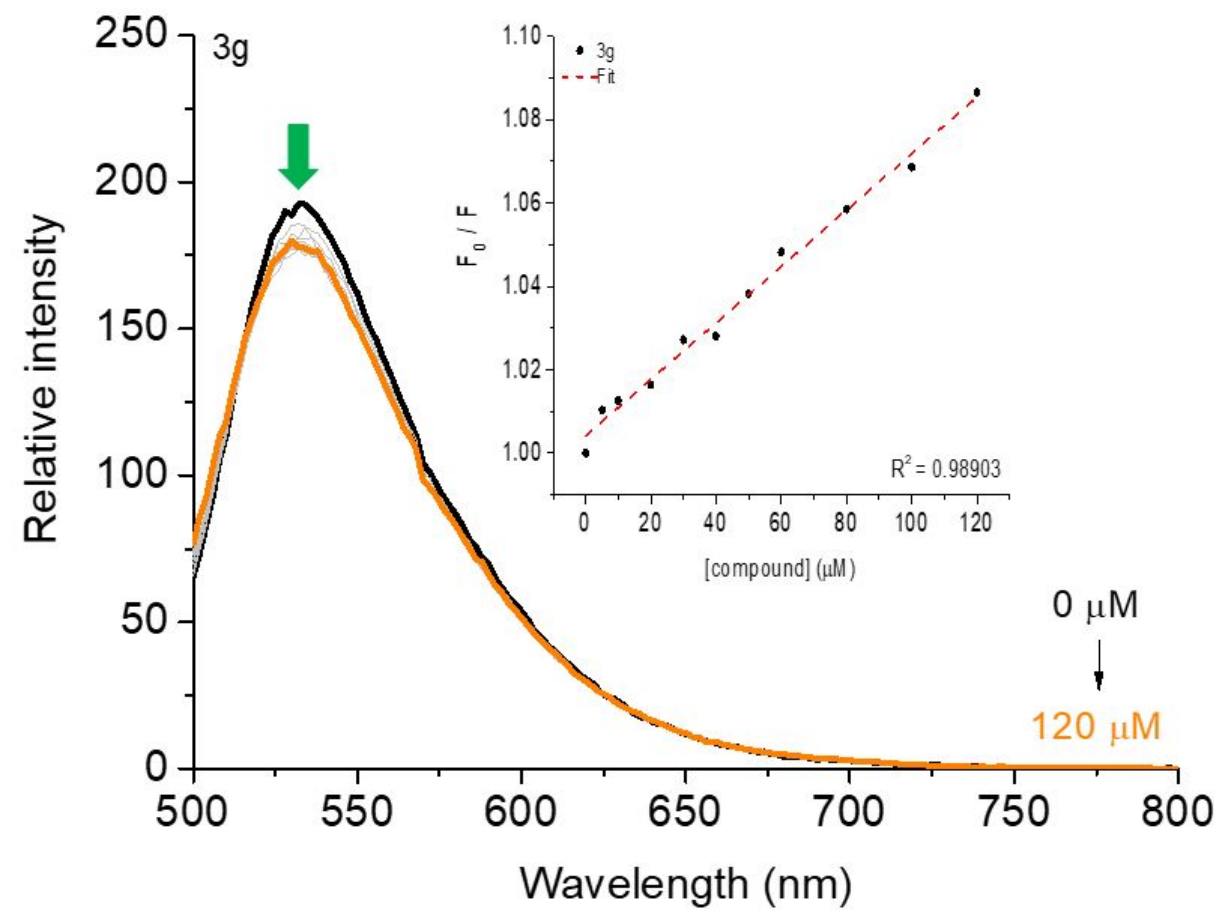

Figure S80. Emission fluorescence spectra of AO:DNA adduct with increase concentrations of derivative $\mathbf{3 g}$, in a DMSO $(5 \%) / T$ ris- $\mathrm{HCl}$ buffer $(\mathrm{pH} 7.4)$ solution (excitation at $481 \mathrm{~nm}$ ). The insert shows the plot of $F_{0} / F$ versus [compound]. 


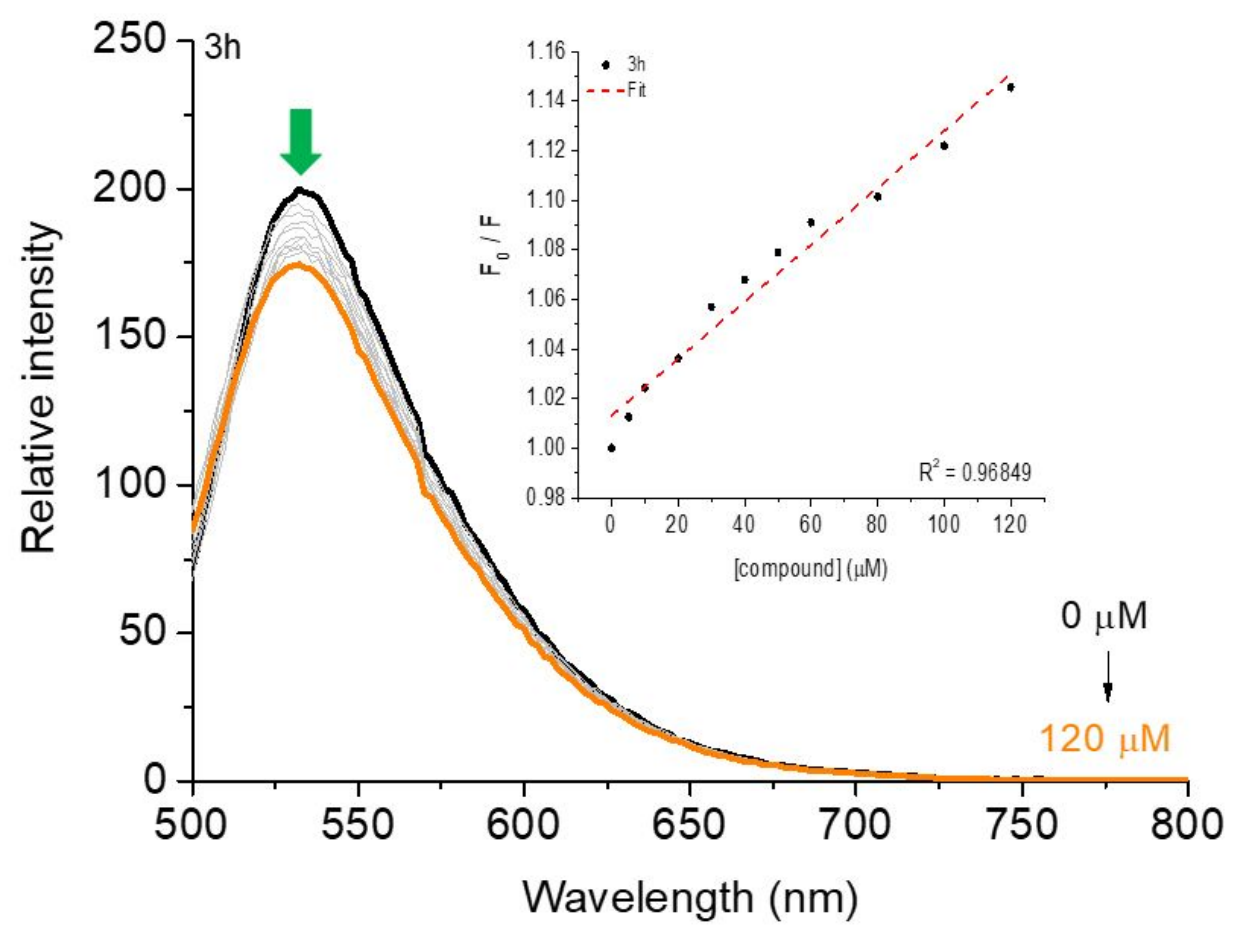

Figure S81. Emission fluorescence spectra of AO:DNA adduct with increase concentrations of derivative $3 \mathrm{~h}$, in a DMSO $(5 \%) / T$ ris- $\mathrm{HCl}$ buffer $(\mathrm{pH} 7.4)$ solution (excitation at $481 \mathrm{~nm}$ ). The insert shows the plot of $\mathrm{F}_{0} / \mathrm{F}$ versus [compound].

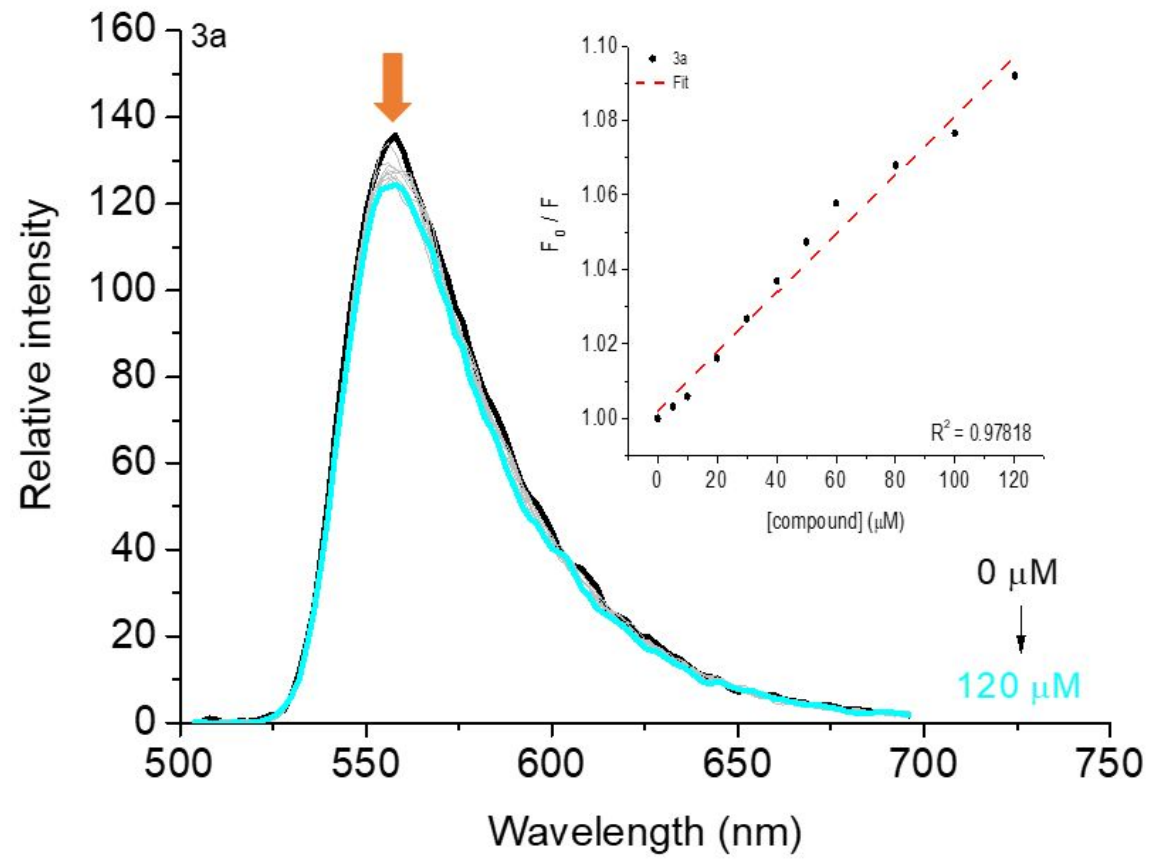

Figure S82. Emission fluorescence spectra of DAPI:DNA adduct with increase concentrations of derivative $3 \mathrm{a}$, in a $\mathrm{DMSO}(5 \%) /$ Tris-HCl buffer $(\mathrm{pH} 7.4)$ solution (excitation at $481 \mathrm{~nm}$ ). The insert shows the plot of $\mathrm{F}_{0} / \mathrm{F}$ versus [compound]. 


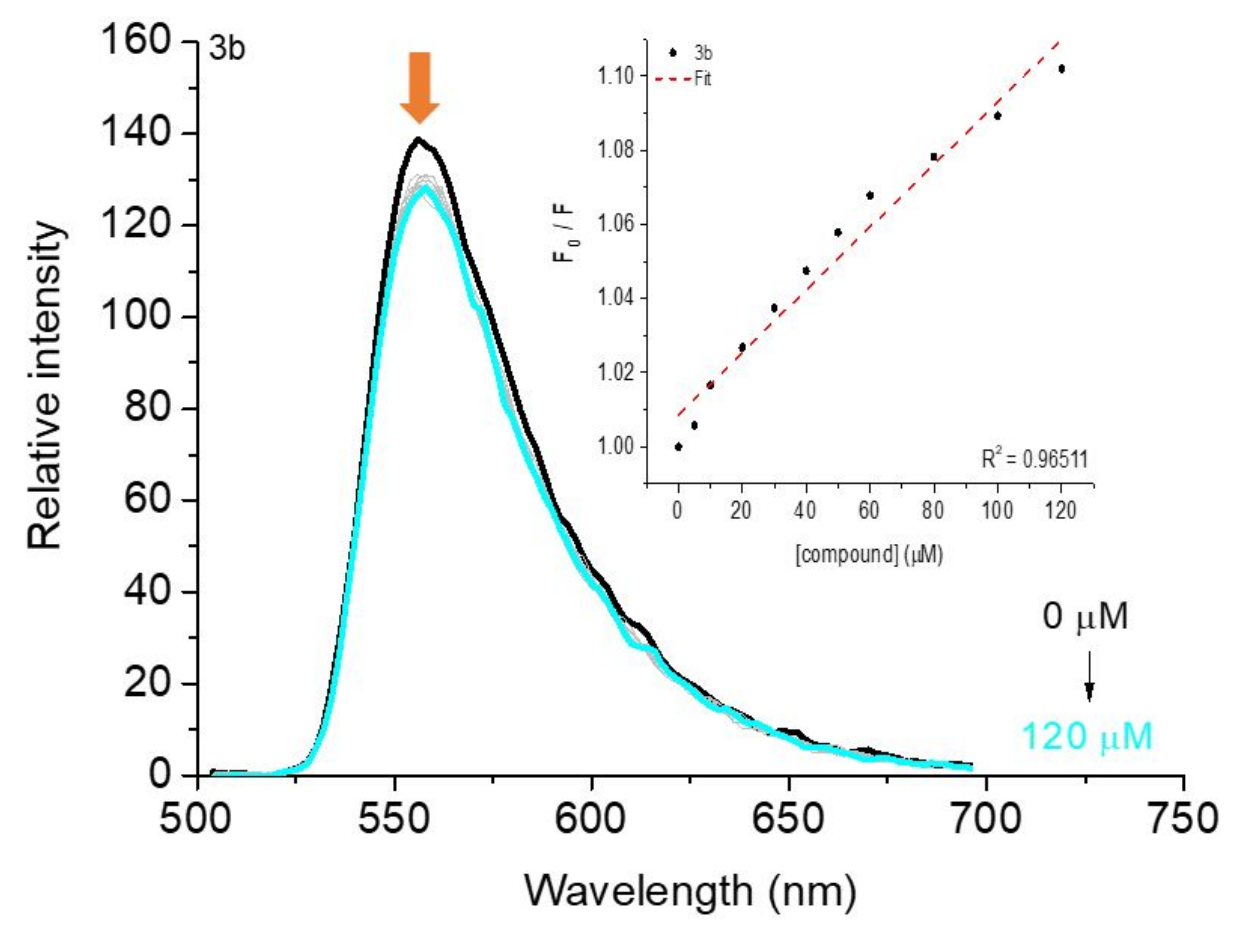

Figure S83. Emission fluorescence spectra of DAPI:DNA adduct with increase concentrations of derivative $\mathbf{3 b}$, in a DMSO $(5 \%) / T$ ris- $\mathrm{HCl}$ buffer $(\mathrm{pH} 7.4)$ solution (excitation at $481 \mathrm{~nm}$ ). The insert shows the plot of $F_{0} / F$ versus [compound].

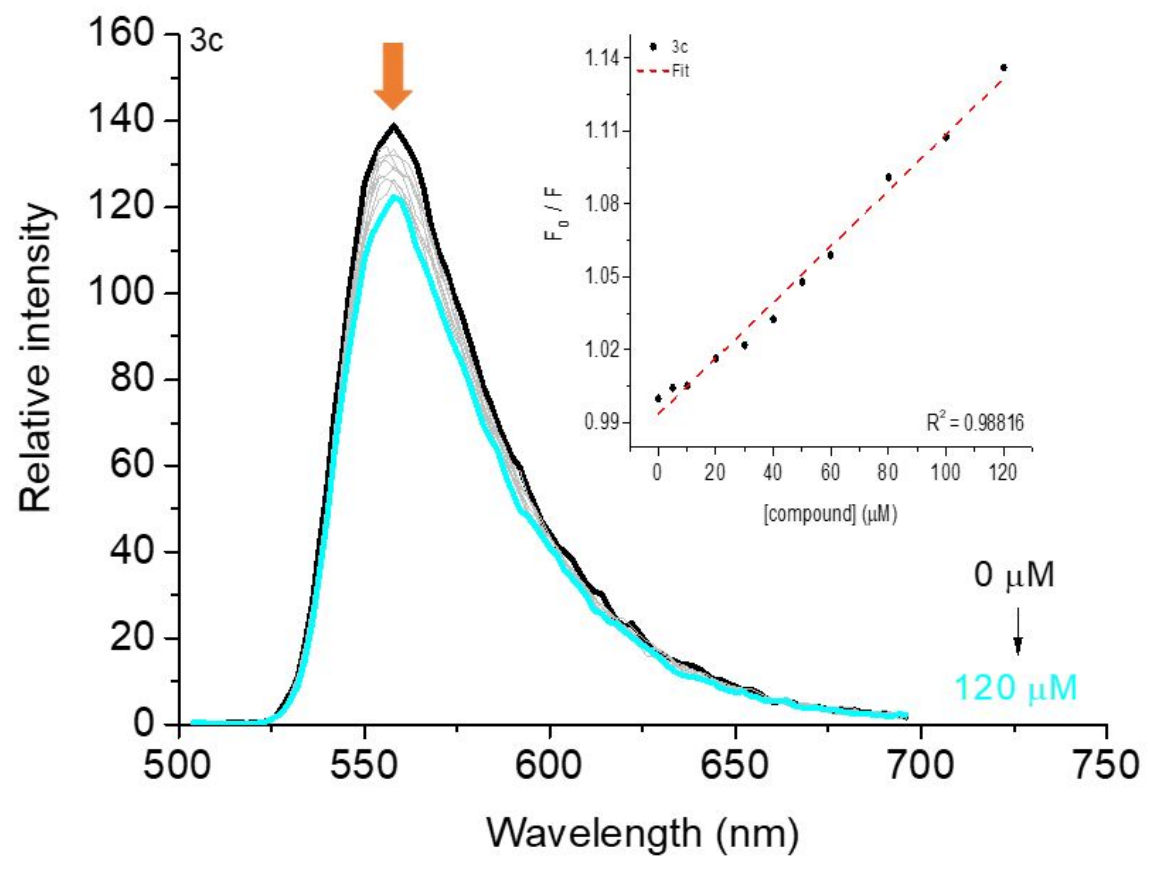

Figure S84. Emission fluorescence spectra of DAPI:DNA adduct with increase concentrations of derivative $3 \mathrm{c}$, in a DMSO $(5 \%) / T$ ris- $\mathrm{HCl}$ buffer $(\mathrm{pH} 7.4)$ solution (excitation at $481 \mathrm{~nm}$ ). The insert shows the plot of $F_{0} / F$ versus [compound]. 


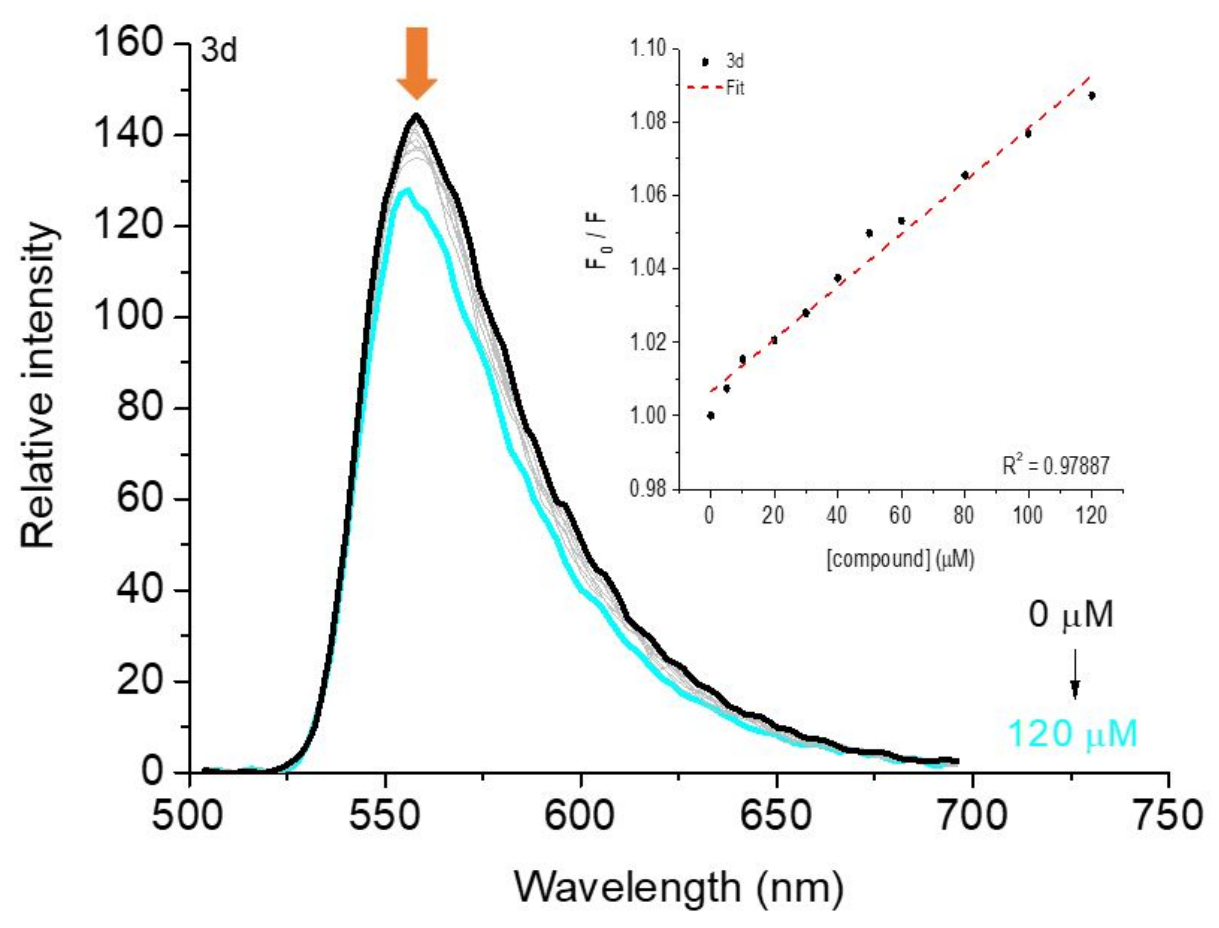

Figure S85. Emission fluorescence spectra of DAPI:DNA adduct with increase concentrations of derivative $\mathbf{3 d}$, in a DMSO $(5 \%) / T$ ris- $\mathrm{HCl}$ buffer $(\mathrm{pH} 7.4)$ solution (excitation at $481 \mathrm{~nm}$ ). The insert shows the plot of $\mathrm{F}_{0} / \mathrm{F}$ versus [compound].

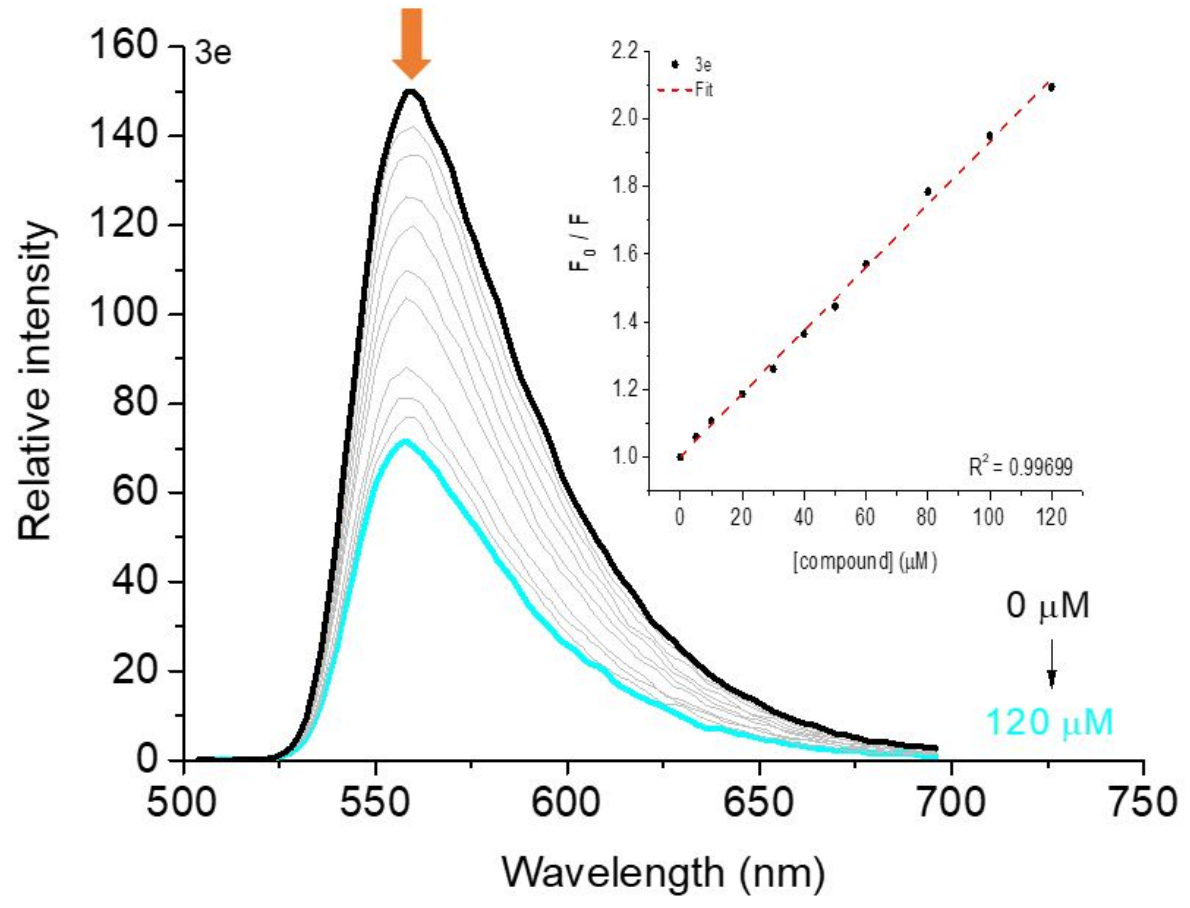

Figure S86. Emission fluorescence spectra of DAPI:DNA adduct with increase concentrations of derivative $3 \mathbf{e}$, in a $\mathrm{DMSO}(5 \%) / T$ ris- $\mathrm{HCl}$ buffer $(\mathrm{pH} 7.4)$ solution (excitation at $481 \mathrm{~nm}$ ). The insert shows the plot of $F_{0} / F$ versus [compound]. 


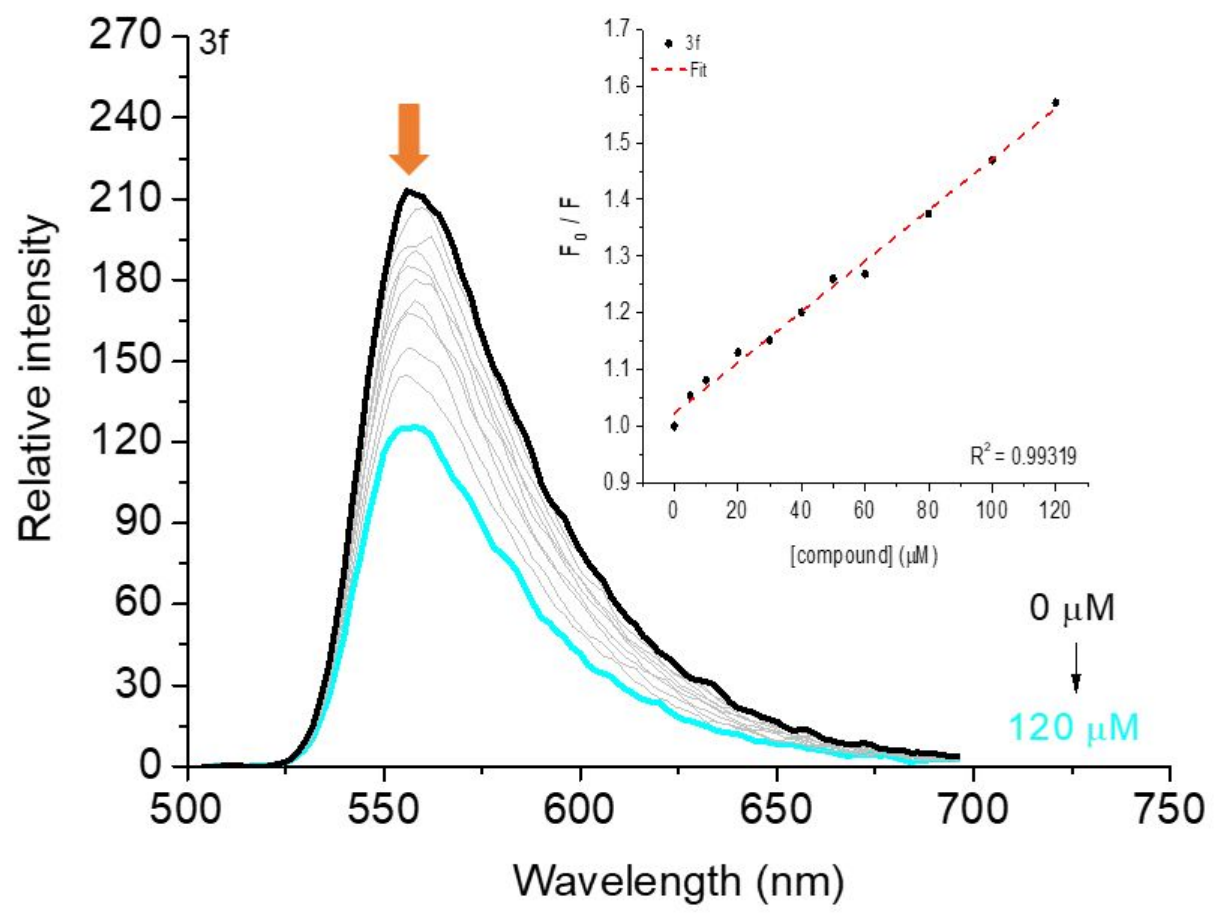

Figure S87. Emission fluorescence spectra of DAPI:DNA adduct with increase concentrations of derivative $\mathbf{3 f}$, in a DMSO $(5 \%) /$ Tris-HCl buffer $(\mathrm{pH} 7.4)$ solution (excitation at $481 \mathrm{~nm}$ ). The insert shows the plot of $F_{0} / F$ versus [compound].

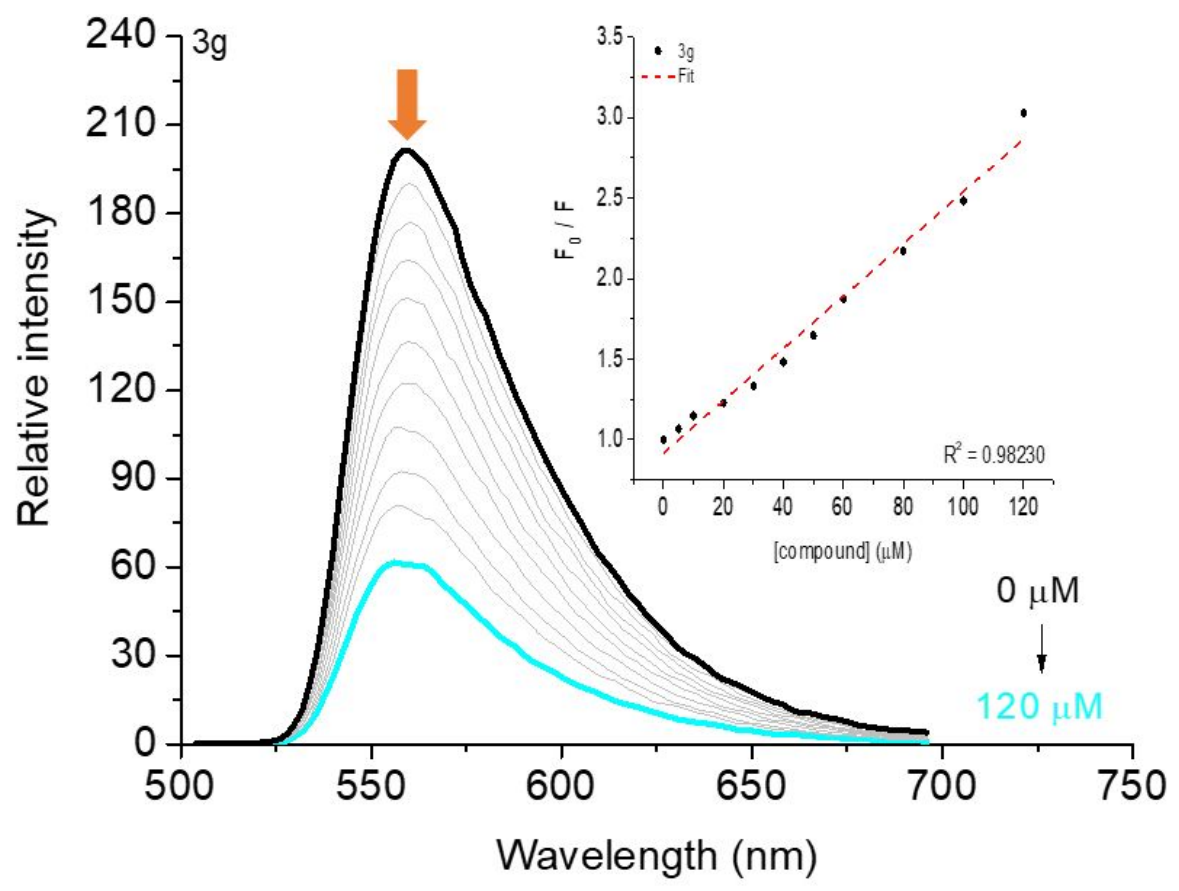

Figure S88. Emission fluorescence spectra of DAPI:DNA adduct with increase concentrations of derivative $\mathbf{3 g}$, in a DMSO $(5 \%) / T$ ris- $\mathrm{HCl}$ buffer $(\mathrm{pH} 7.4)$ solution (excitation at $481 \mathrm{~nm}$ ). The insert shows the plot of $\mathrm{F}_{0} / \mathrm{F}$ versus [compound]. 


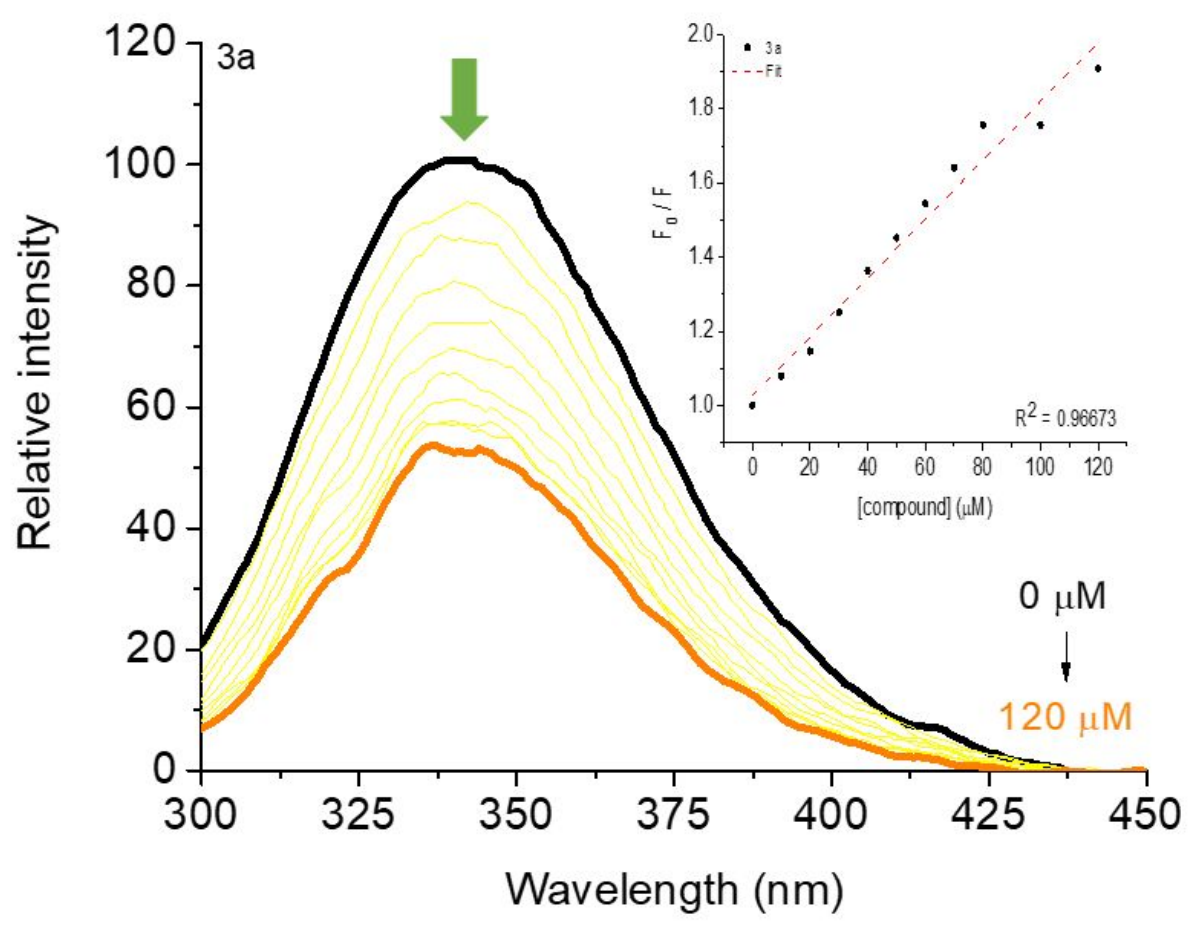

Figure S89. BSA emission fluorescence spectra with increase concentrations of derivative 3a, in a $\mathrm{DMSO}(5 \%) / \mathrm{Tris}-\mathrm{HCl}$ buffer $(\mathrm{pH} 7.4)$ solution (excitation at 290 $\mathrm{nm})$. The insert shows the plot of $\mathrm{F}_{0} / \mathrm{F}$ versus [compound].

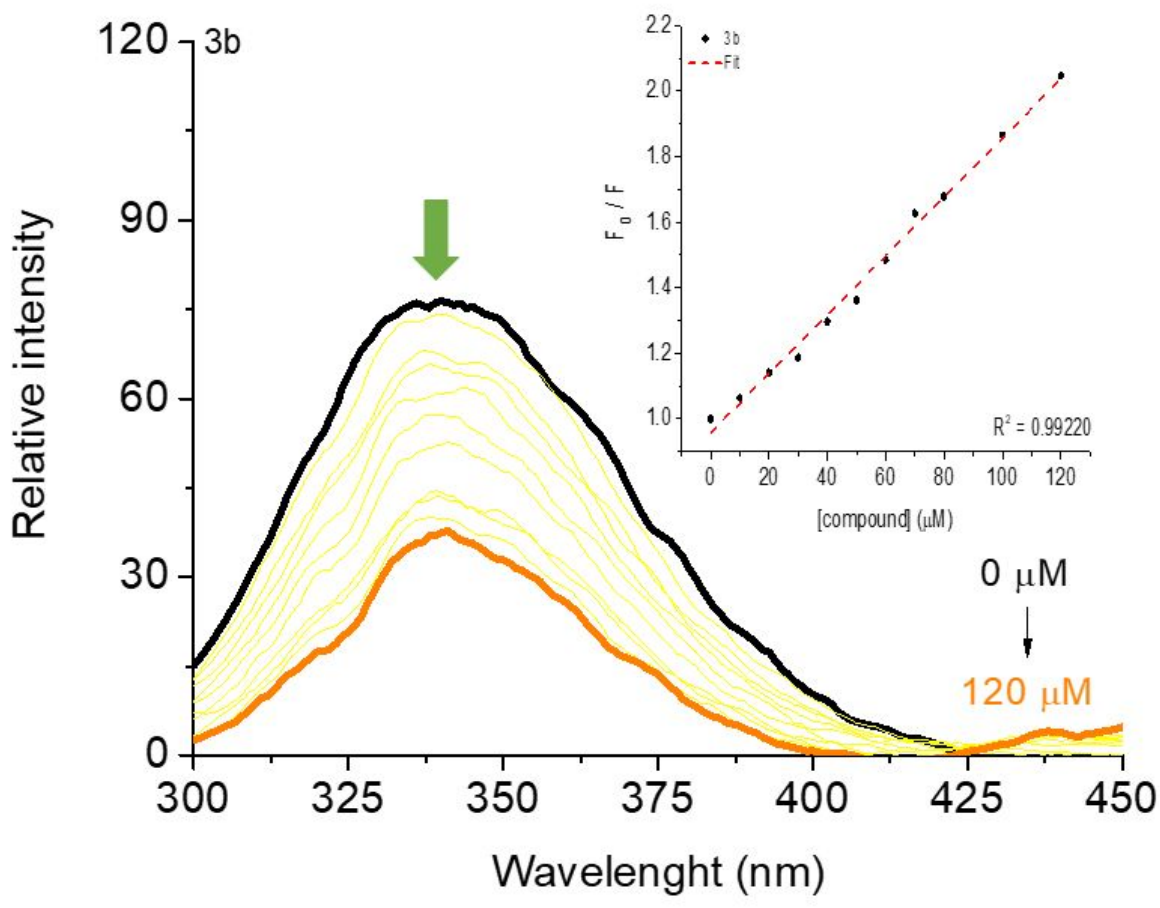

Figure S90. BSA emission fluorescence spectra with increase concentrations of derivative $3 \mathbf{b}$, in a DMSO $(5 \%) /$ Tris- $\mathrm{HCl}$ buffer $(\mathrm{pH} 7.4)$ solution (excitation at 290 $n m$ ). The insert shows the plot of $F_{0} / F$ versus [compound]. 


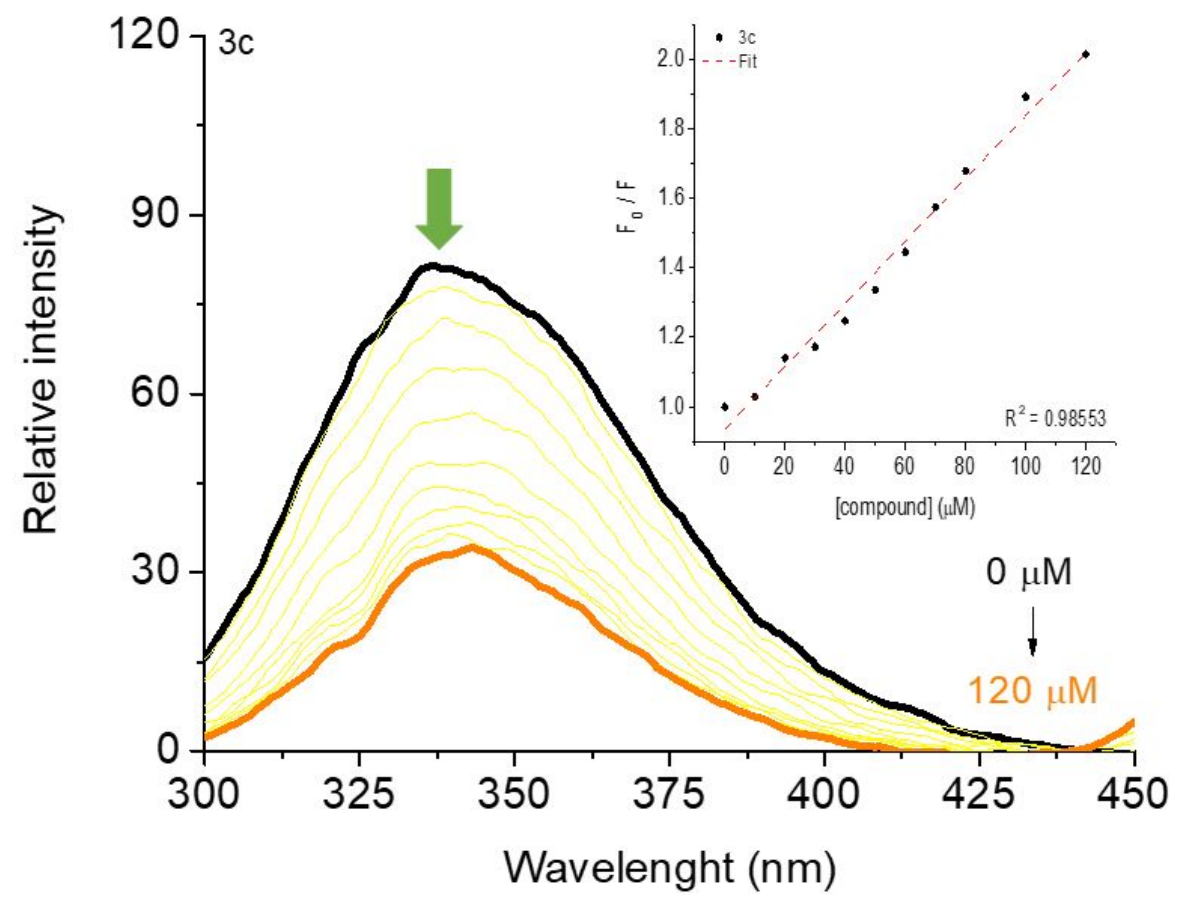

Figure S91. BSA emission fluorescence spectra with increase concentrations of derivative 3c, in a $\mathrm{DMSO}(5 \%) / \mathrm{Tris}-\mathrm{HCl}$ buffer $(\mathrm{pH} 7.4)$ solution (excitation at 290 $\mathrm{nm})$. The insert shows the plot of $\mathrm{F}_{0} / \mathrm{F}$ versus [compound].

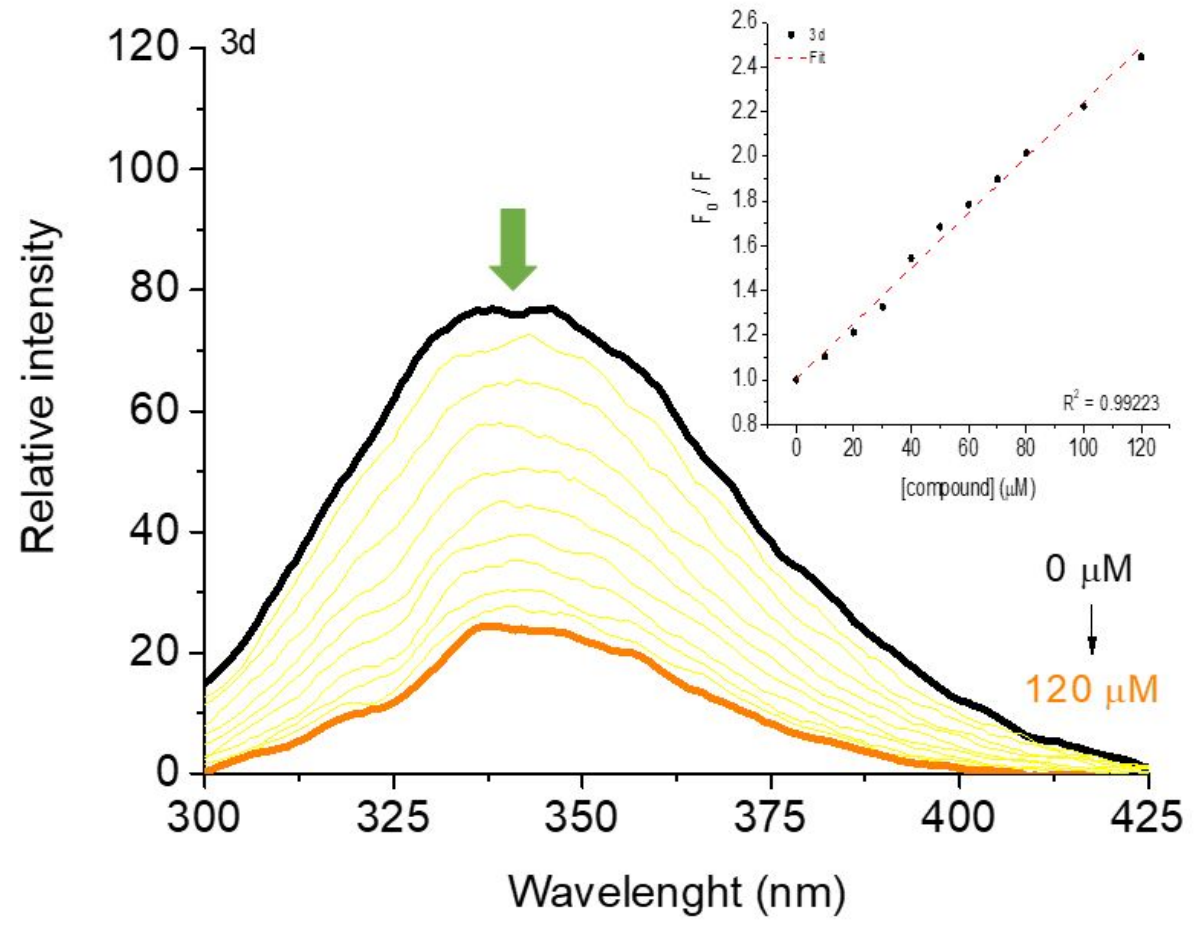

Figure S92. BSA emission fluorescence spectra with increase concentrations of derivative 3d, in a DMSO(5\%)/Tris- $\mathrm{HCl}$ buffer $(\mathrm{pH} 7.4)$ solution (excitation at 290 $\mathrm{nm})$. The insert shows the plot of $\mathrm{F}_{0} / \mathrm{F}$ versus [compound]. 


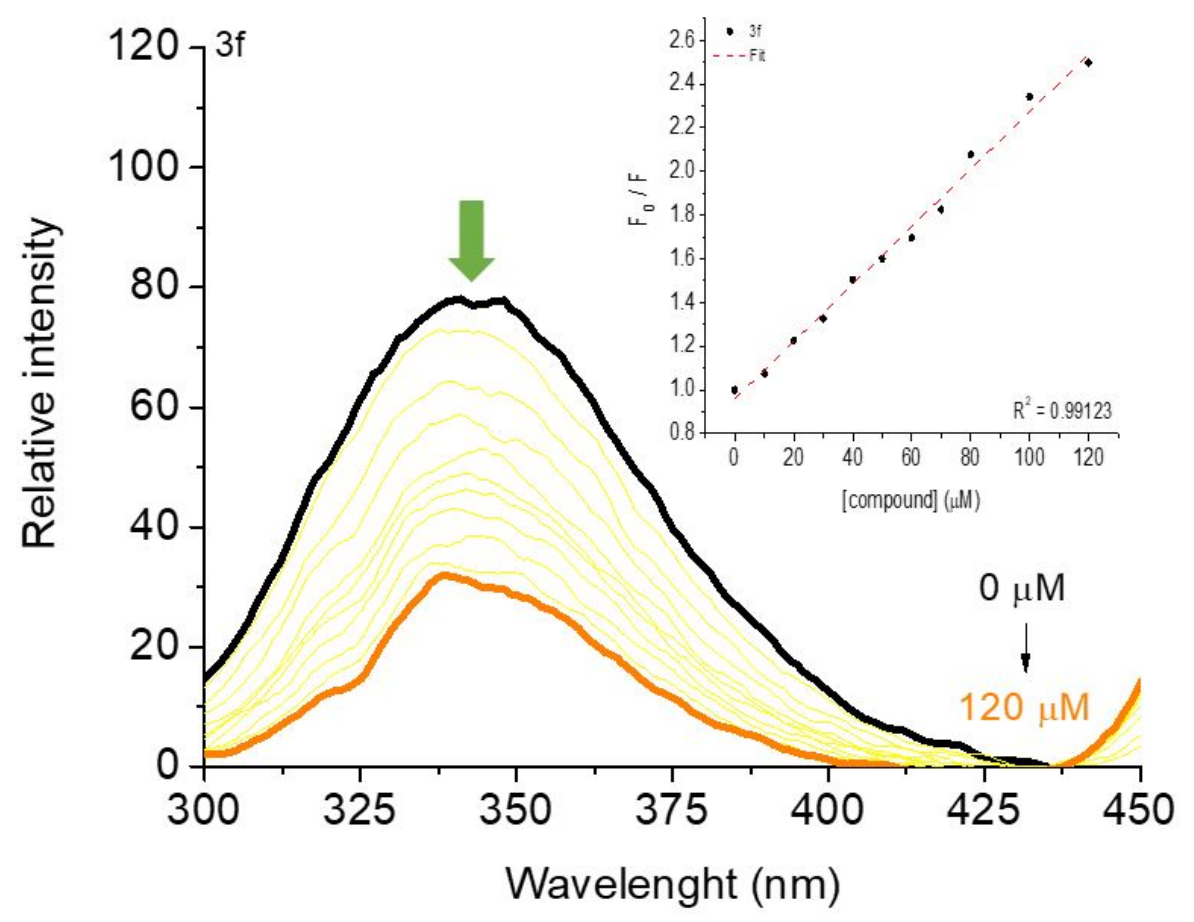

Figure S93. BSA emission fluorescence spectra with increase concentrations of derivative 3f, in a DMSO(5\%)/Tris- $\mathrm{HCl}$ buffer $(\mathrm{pH} \mathrm{7.4)} \mathrm{solution} \mathrm{(excitation} \mathrm{at} 290$ $n m)$. The insert shows the plot of $F_{0} / F$ versus [compound].

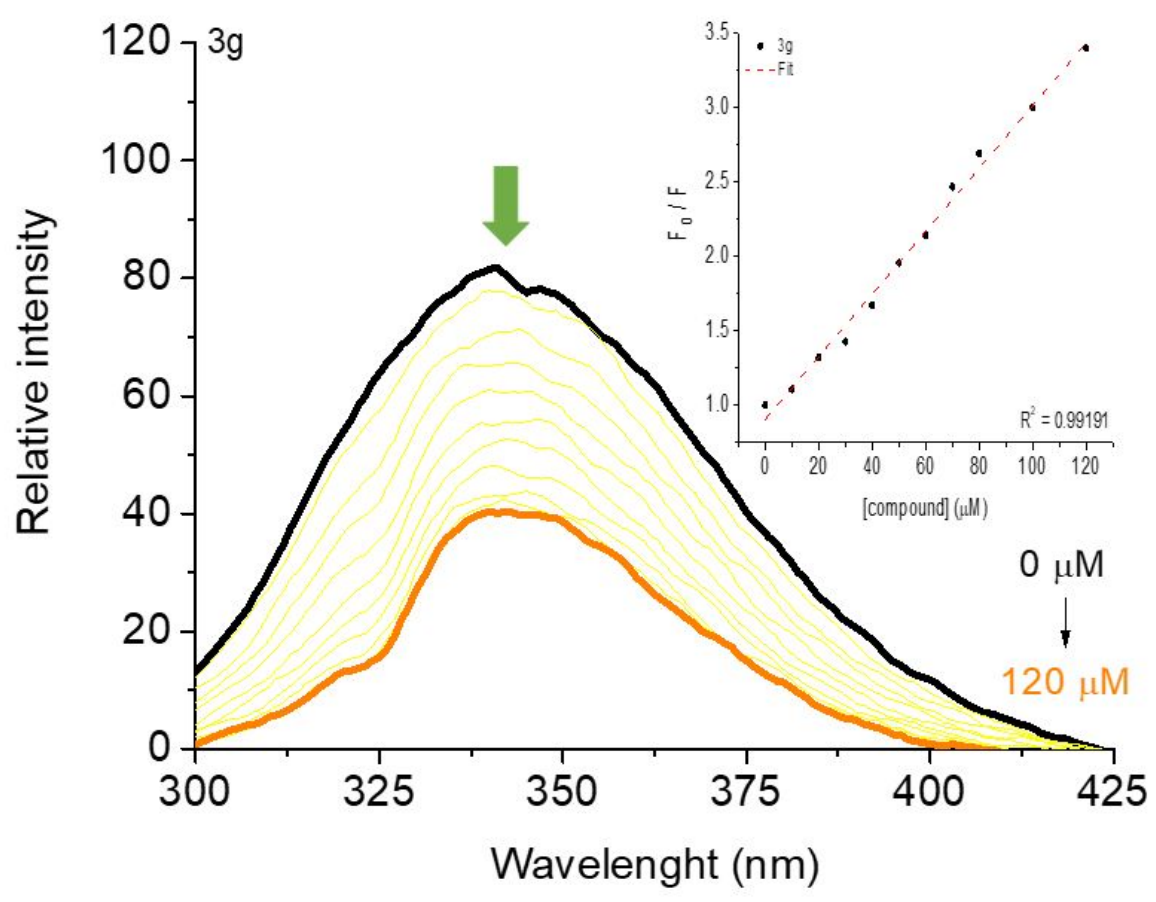

Figure S94. BSA emission fluorescence spectra with increase concentrations of derivative $3 \mathbf{g}$, in a DMSO $(5 \%) / T r i s-H C l$ buffer $(\mathrm{pH} 7.4)$ solution (excitation at 290 $n m)$. The insert shows the plot of $F_{0} / F$ versus [compound]. 


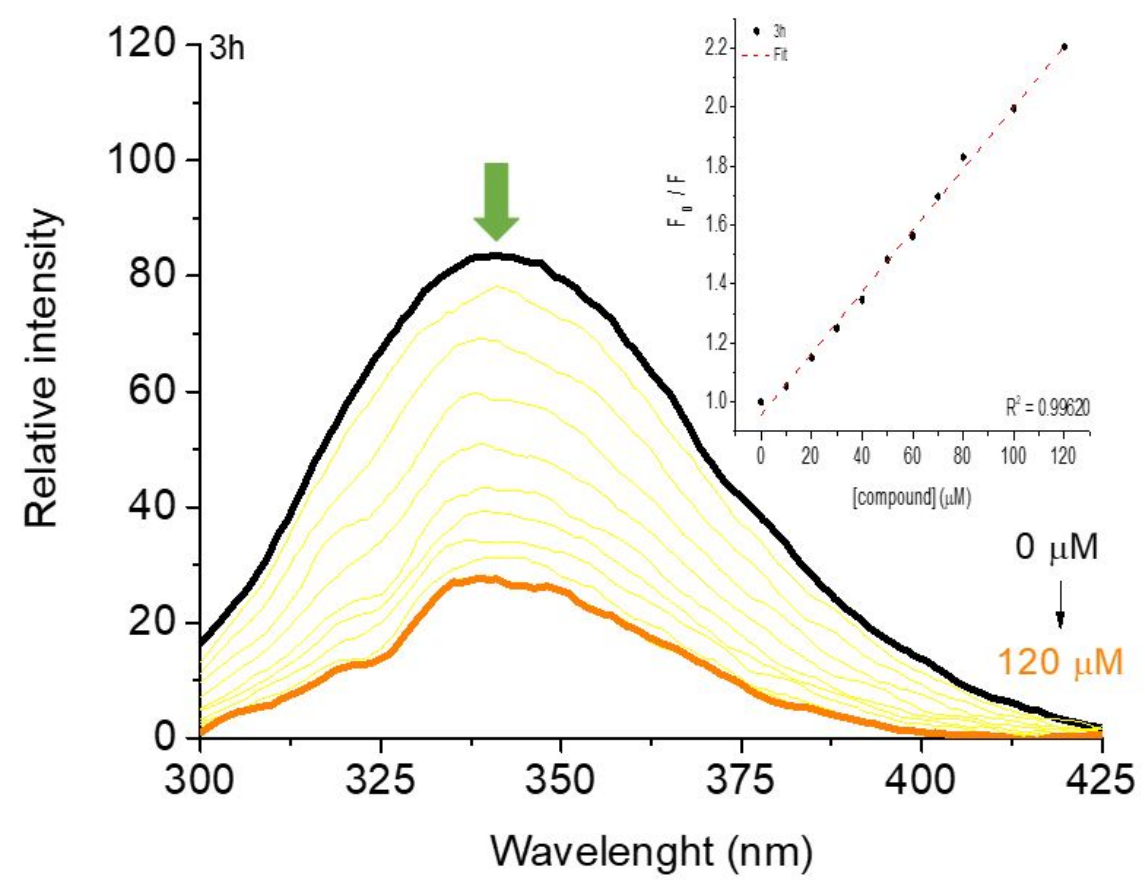

Figure S95. BSA emission fluorescence spectra with increase concentrations of derivative $\mathbf{3 h}$, in a DMSO $(5 \%) / T$ ris- $\mathrm{HCl}$ buffer $(\mathrm{pH} 7.4)$ solution (excitation at 290 $n m$ ). The insert shows the plot of $F_{0} / F$ versus [compound].

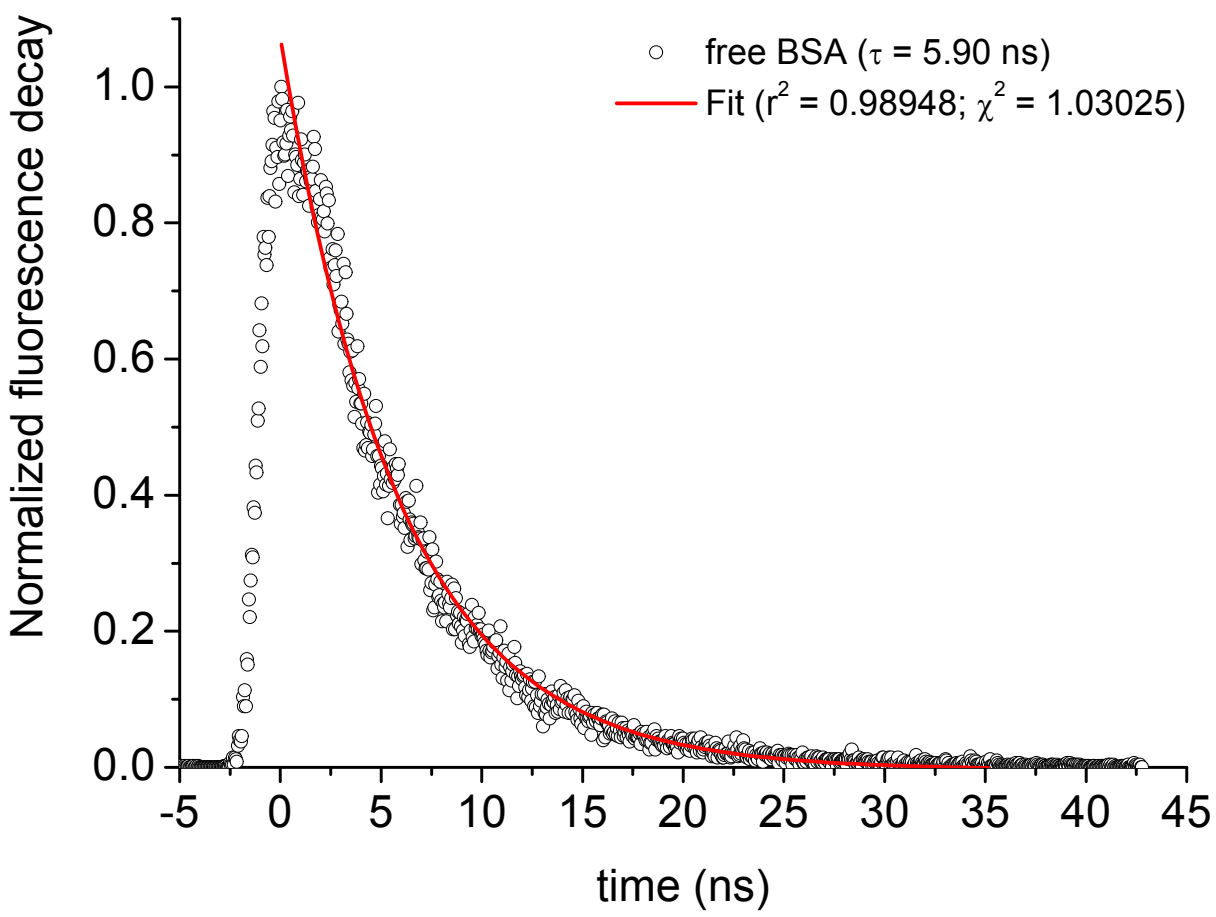

Figure S96. Fluorescence decay time of free $\mathrm{BSA}$ in a $\mathrm{DMSO}(5 \%) / \mathrm{Tris}-\mathrm{HCl}$ buffer ( $\mathrm{pH} 7.4$ ) solution (excitation at $284 \mathrm{~nm}$ ). 


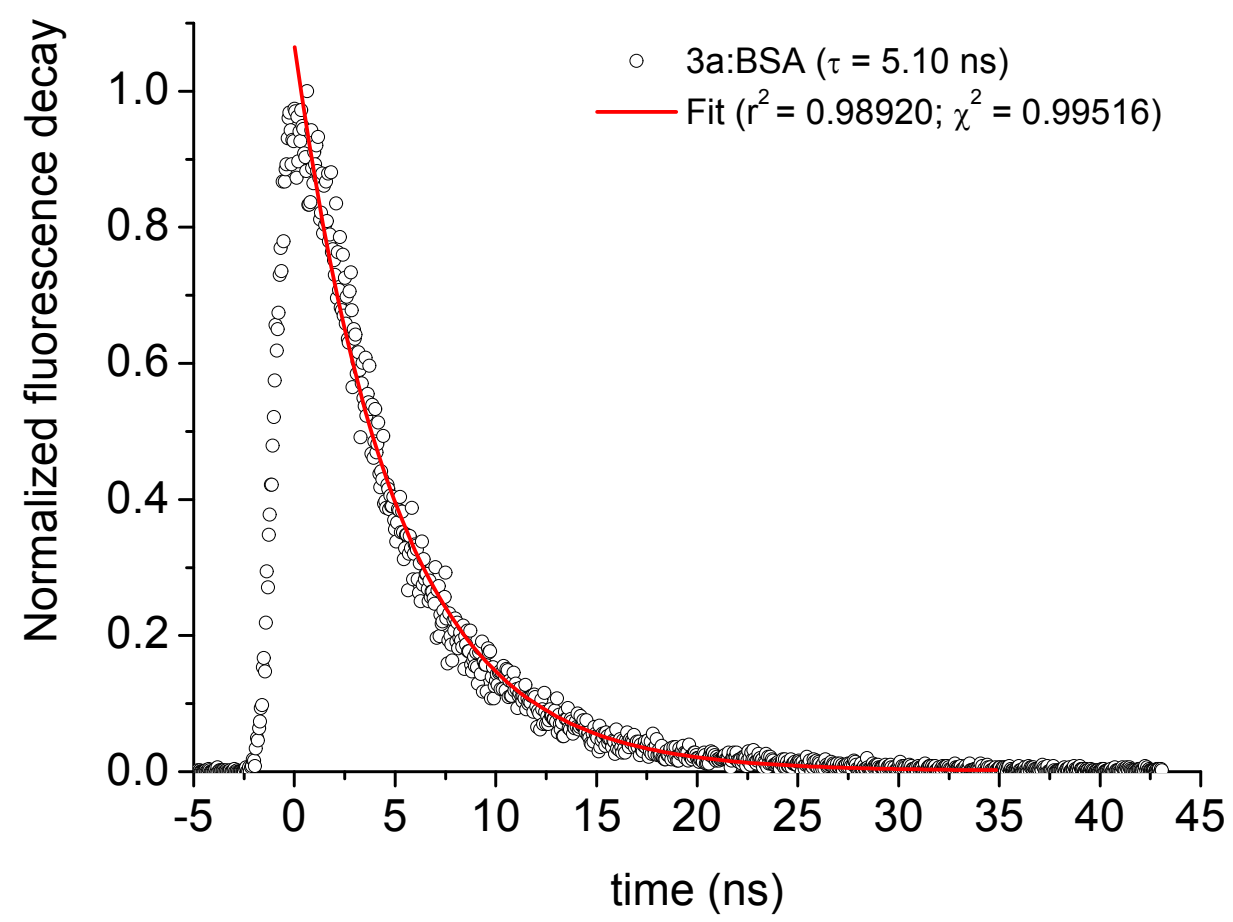

Figure S97. Fluorescence decay time of BSA with compound $\mathbf{3 a}$ in a $\mathrm{DMSO}(5 \%) /$ Tris- $\mathrm{HCl}$ buffer $(\mathrm{pH} 7.4)$ solution (excitation at $284 \mathrm{~nm}$ ).

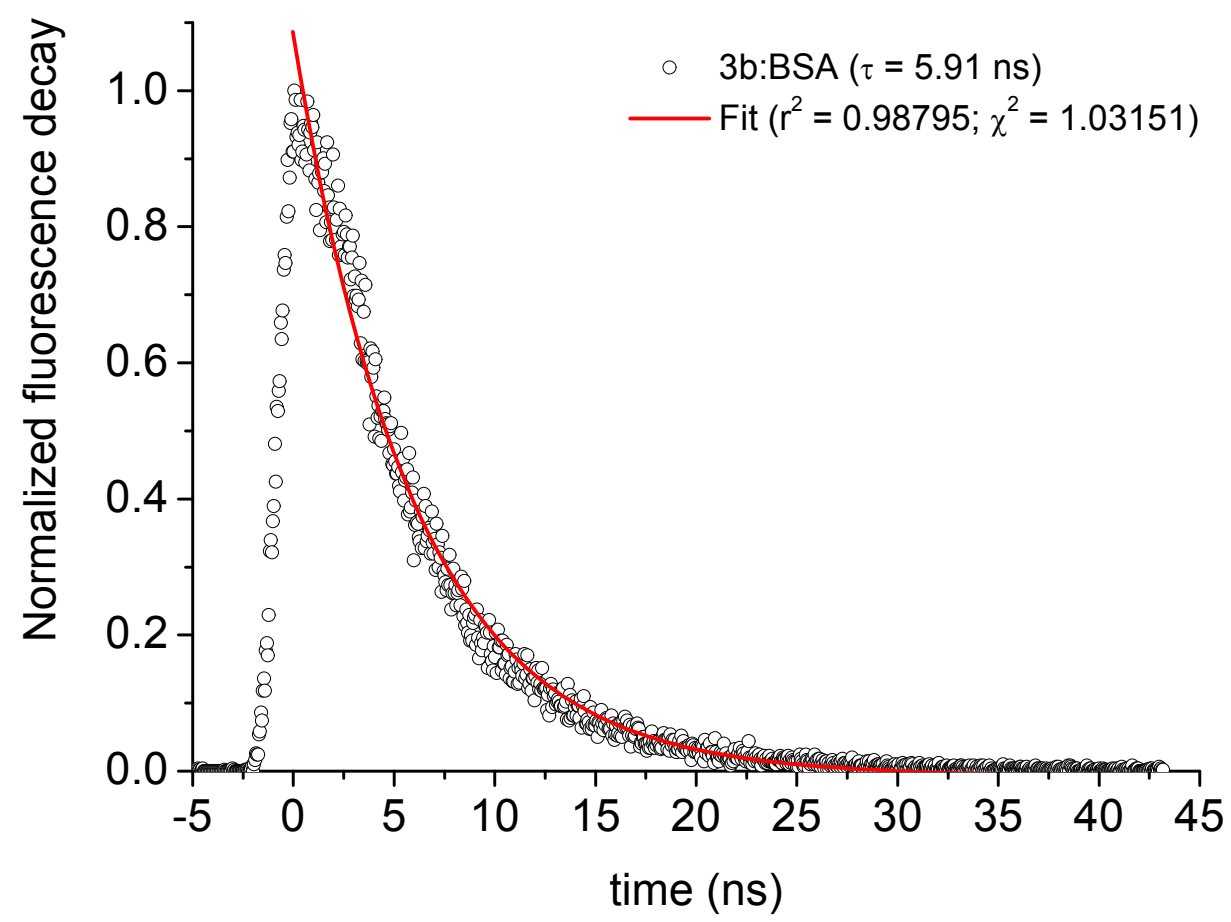

Figure S98. Fluorescence decay time of BSA with compound $\mathbf{3 b}$ in $\mathbf{a}$ DMSO(5\%)/Tris- $\mathrm{HCl}$ buffer ( $\mathrm{pH} 7.4)$ solution (excitation at $284 \mathrm{~nm}$ ). 


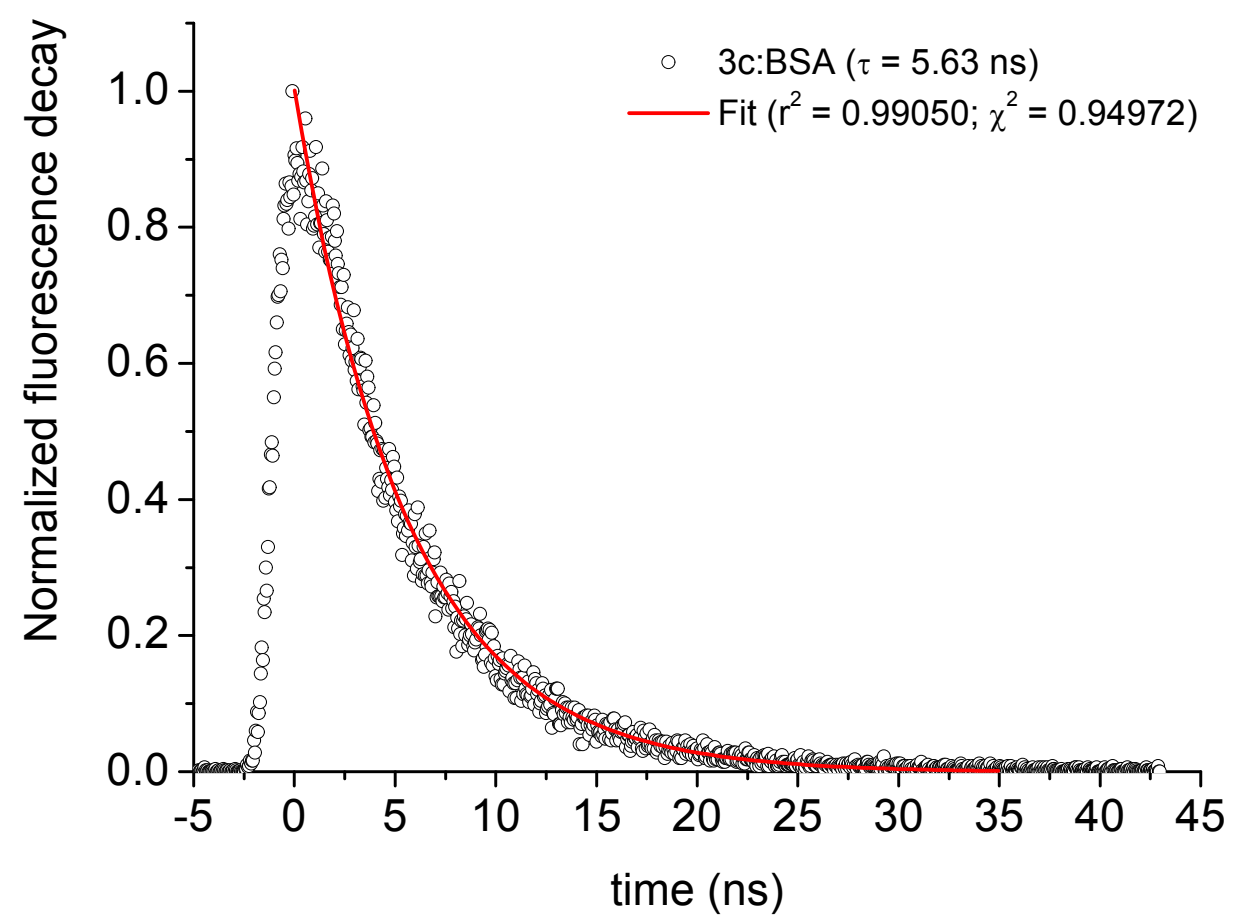

Figure S99. Fluorescence decay time of BSA with compound $3 \mathrm{c}$ in a $\mathrm{DMSO}(5 \%) /$ Tris- $\mathrm{HCl}$ buffer $(\mathrm{pH} 7.4)$ solution (excitation at $284 \mathrm{~nm}$ ).

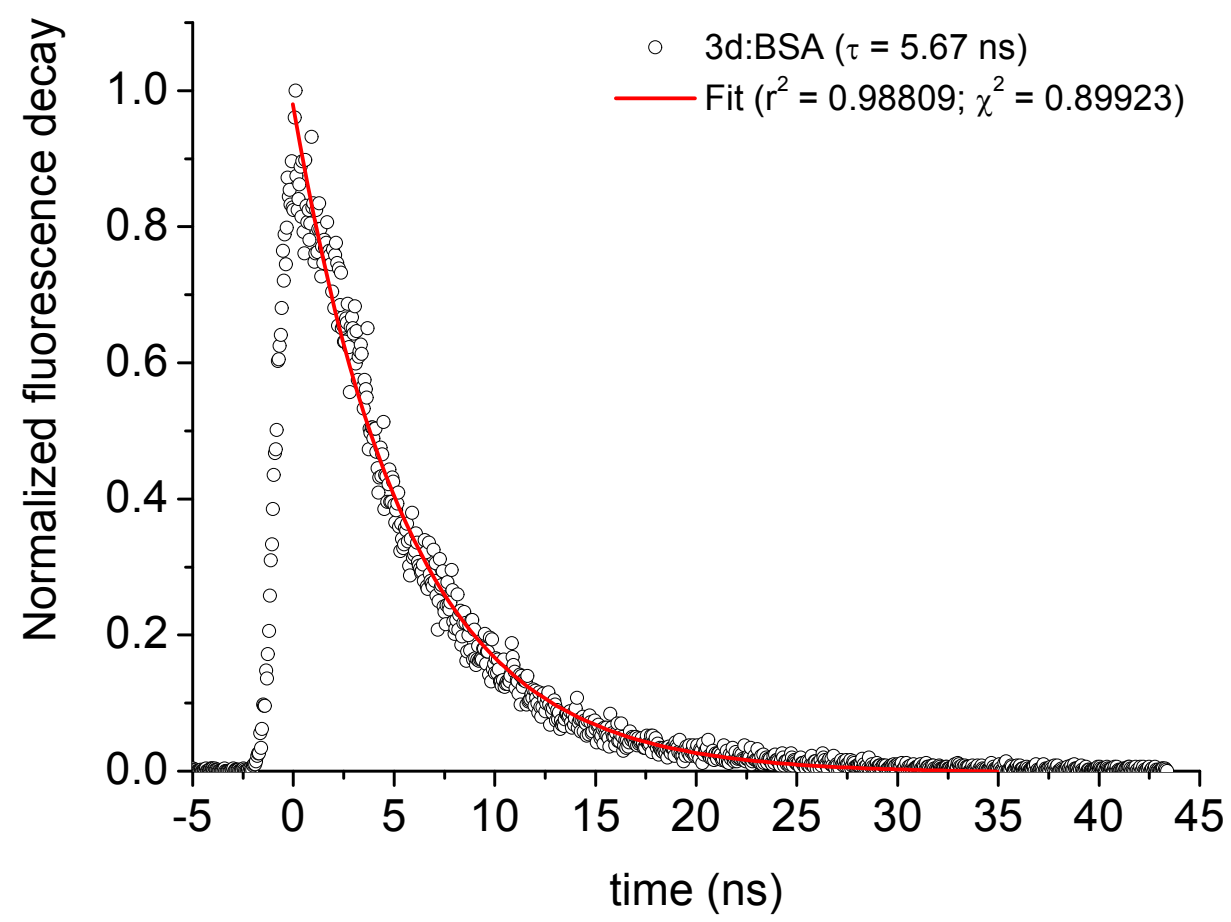

Figure S100. Fluorescence decay time of BSA with compound $\mathbf{3 d}$ in a DMSO(5\%)/Tris-HCl buffer ( $\mathrm{pH} 7.4)$ solution (excitation at $284 \mathrm{~nm}$ ). 


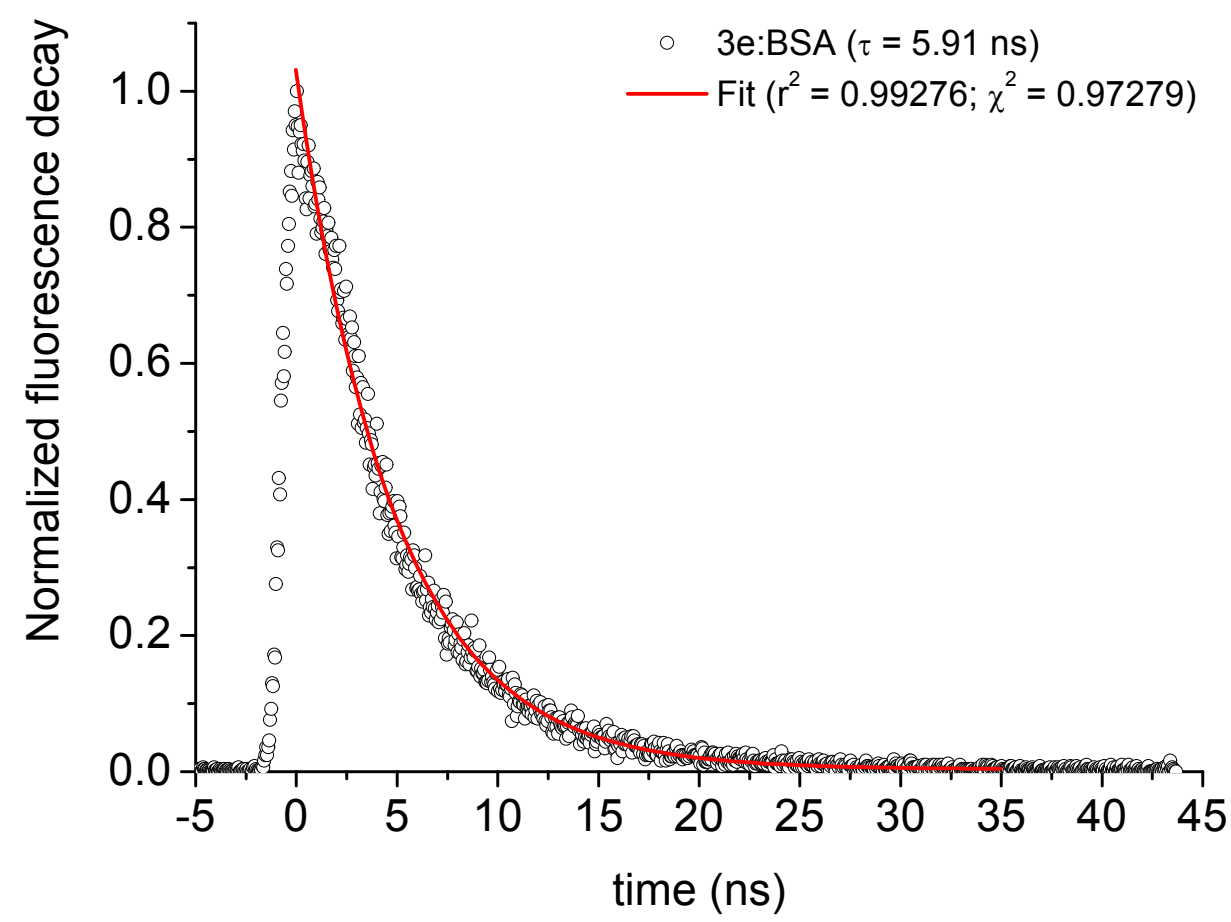

Figure S101. Fluorescence decay time of BSA with compound $3 e$ in a $\mathrm{DMSO}(5 \%) / T$ ris- $\mathrm{HCl}$ buffer $(\mathrm{pH} 7.4)$ solution (excitation at $284 \mathrm{~nm}$ ).

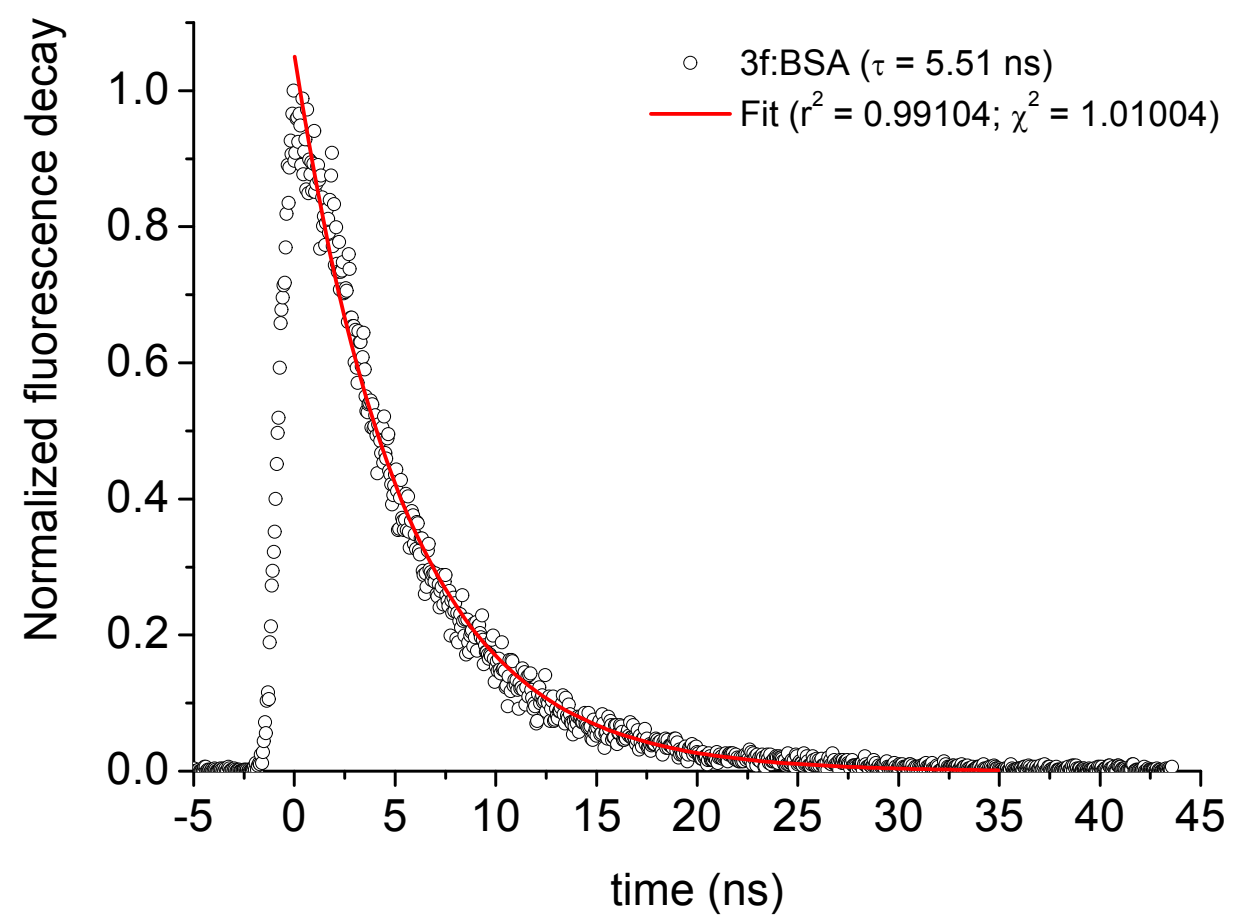

Figure S102. Fluorescence decay time of BSA with compound $3 f$ in a DMSO(5\%)/Tris-HCl buffer ( $\mathrm{pH} 7.4)$ solution (excitation at $284 \mathrm{~nm}$ ). 


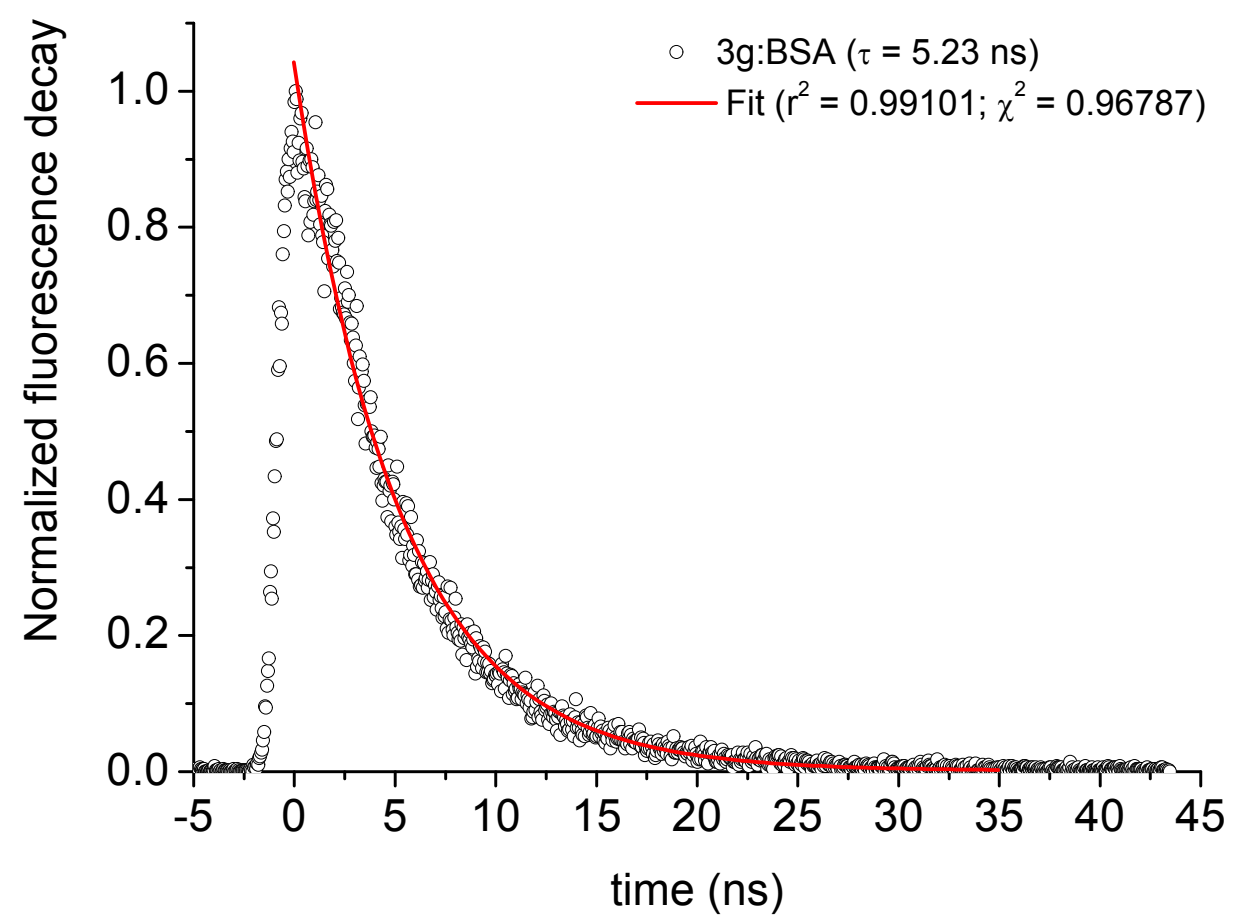

Figure S103. Fluorescence decay time of BSA with compound $\mathbf{3 g}$ in a $\mathrm{DMSO}(5 \%) /$ Tris- $\mathrm{HCl}$ buffer $(\mathrm{pH} \mathrm{7.4)}$ solution (excitation at $284 \mathrm{~nm}$ ).

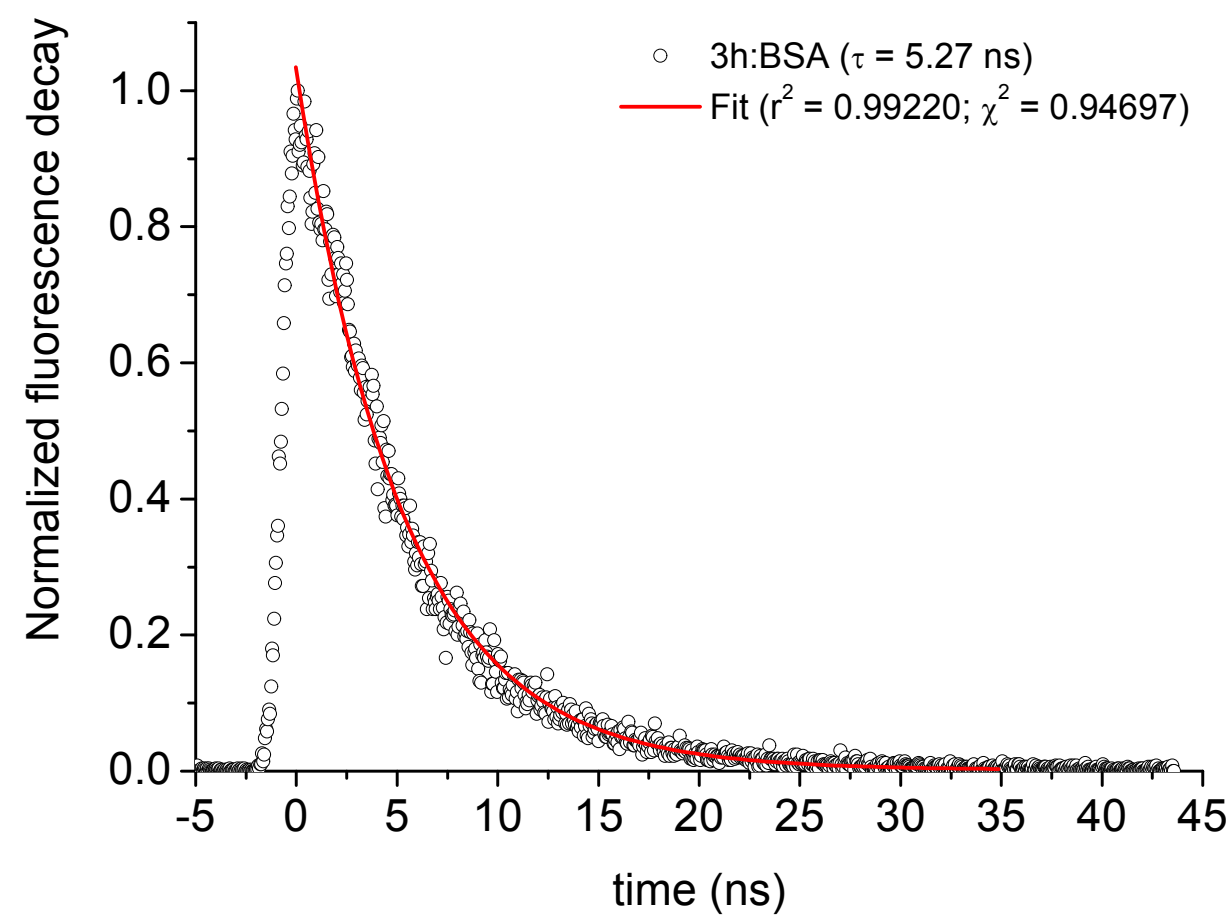

Figure S104. Fluorescence decay time of BSA with compound $3 \mathrm{~h}$ in a DMSO(5\%)/Tris-HCl buffer ( $\mathrm{pH} 7.4)$ solution (excitation at $284 \mathrm{~nm}$ ). 